Dagmara WÓJCIK-ZEGA

Uniwersytet Jagielloński

\title{
Autografy piętnastowiecznych profesorów krakowskich w rękopisie Archiwum Uniwersytetu Jagiellońskiego 63*
}

Kolegium Królewskie Uniwersytetu Krakowskiego, od 1449 r. zwane też Większym, powołał do istnienia król Władysław Jagiełło 22 VII 1400 r. ${ }^{1}$ Stanowiło ono autonomiczną korporację wewnątrz uniwersytetu ${ }^{2}$. Świadczy o tym fakt posiadania własnych statutów ${ }^{3}$, samorządu, pieczęci ${ }^{4}$, wewnętrznego sądownictwa i autonomii finansowej ${ }^{5}$. Obok tekstu normatywnego, jakim były uchwalone w 1429 r. statuty Kolegium, zachował się szereg źródeł dokumentujących funkcjonowanie tej korporacji w XV w. Najstarszym z nich jest Liber conclusionum (LC) w rękopisie Archiwum Uniwersytetu Jagiellońskiego w Krakowie [dalej: AUJ] o sygnaturze 63. Dokumentuje on działalność korporacyjnego samorządu Kolegium Królewskiego w latach 1432-1591.

Rękopis bywał kilkakrotnie przedmiotem zainteresowania badaczy średniowiecznego Uniwersytetu Krakowskiego ${ }^{6}$, lecz dotychczasowe publikacje dalekie są od wyczerpania bogactwa jego treści. Celem artykułu jest przedstawienie kodykologicznych i paleograficznych aspektów tego interesującego źródła.

Artykuł podzielony jest na pięć rozdziałów. Pierwszy rozdział prezentuje materialną stronę rękopisu. W rozdziale drugim omówiono te aspekty struktury prawno-organizacyjnej Kolegium Królew-

* Za przyjacielską, czyli krytyczną, lekturę i uwagi do artykułu serdecznie dziękuję mojemu Mężowi dr. Włodzimierzowi Zedze, Pani Doktor Lucynie Nowak i Panu Doktorowi Ryszardowi Tatarzyńskiemu, znakomitym specjalistom w zakresie średniowiecznych kodeksów Uniwersytetu Jagiellońskiego i paleografii z Oddziału Rękopisów Biblioteki Jagiellońskiej w Krakowie, członkom zespołu opracowującego katalog łacińskich rękopisów średniowiecznych.

${ }^{1}$ CDUJ, t. 1, nr 16.

2 Z. Kozłowska-Budkowa, Odnowienie Jagiellońskie Uniwersytetu Krakowskiego (1390-1414), w: Dzieje Uniwersytetu Jagiellońskiego w latach 1364-1764, t. 1, red. K. Lepszy, Kraków 1964, s. 76; J. Wyrozumski, Kolegia i bursy Uniwersytetu Krakowskiego, w: tegoż, Z najstarszych dziejów Uniwersytetu Krakowskiego. Szkice, Kraków 1996, s. 68 pisał, że „collegium i contubernium stają się zatem zasadniczymi korporacjami odnowionego Uniwersytetu".

3 Statuta antiqua Collegii Maioris, wyd. J. Szujski, „Archiwum do Dziejów Literatury i Oświaty w Polsce” [dalej: ADLOP], 1, 1878, s. 6 n.

${ }^{4}$ A. Chmiel, Pieczęcie Uniwersytetu Jagiellońskiego w Krakowie, oprac. i przedmowa Z. Piech, Kraków 1996, s. 51-57 oraz Z. Piech, Przedmowa, tamże, s. 16 n.

5 W. Bukowski, Z najstarszych dziejów skarbowości Uniwersytetu Krakowskiego. Rachunki prokuratorów generalnych za lata 1458-1490, w: Miasta — ludzie — instytucje — znaki. Księga jubileuszowa ofiarowana profesor Bożenie Wyrozumskiej w 75. rocznice urodzin, red. Z. Piech, Kraków 2008, s. 655.

6 J. Szujski, Założenie i urządzenie Collegii Minoris, ADLOP, 1, 1878, s. 95-97; K. Morawski, Historia Uniwersytetu Jagiellońskiego. Średnie wieki i odrodzenie. Z wstępem o Uniwersytecie Kazimierza Wielkiego, Kraków 1900, t. 1, s. 424 et passim; tamże, t. 2, s. 420 n., 427 et passim; M. Zwiercan, Komentarz Jana z Dąbrówki do Kroniki mistrza Wincentego zwanego Kadtubkiem, Wrocław-Warszawa-Kraków 1969, s. 159 oraz fot. 10; M. Markowski, Dzieje Wydziału Teologii Uniwersytetu Krakowskiego w latach 1397-1525, Kraków 1996, s. 181 et passim; A. Włodarek, Architektura średniowiecznych kolegiów i burs Uniwersytetu Krakowskiego, Kraków 2000, s. 95, 113. 
skiego, które wpłynęły na powstanie i zawartość rękopisu. Następnie przedstawione zostały wnioski dotyczące trybu wnoszenia wpisów do księgi (rozdział 3) oraz kręgu potencjalnych pisarzy (rozdział 4). Artykuł zamyka rozdział piąty, w którym podano listę zidentyfikowanych pisarzy rękopisu $L C$ wraz z podobiznami ich autografów.

\section{Prezentacja rękopisu ${ }^{7}$}

Rękopis Archiwum Uniwersytetu Jagiellońskiego w Krakowie o sygnaturze 63, to papierowy kodeks formatu $4^{\circ}(22,5 \times 16 \mathrm{~cm})$. Składają się nań 94 karty papierowe (ss. 1-188) oraz karta tytułowa pozbawiona paginacji. Zakres chronologiczny rękopisu to lata 1432-1591. Językiem rękopisu jest język łaciński, w kilku zapiskach występują również słowa w języku polskim.

W kompozycji kodeksu wyróżniają się dwie części, które odpowiadają dwóm głównym etapom jego powstawania: średniowiecznemu i nowożytnemu. Część pierwotna, średniowieczna, zbudowana jest z sześciu składek opatrzonych kustoszami (nieliczbowana karta tytułowa oraz ss. 1-122) i datuje się ją na początek lat trzydziestych XV w. ${ }^{8} \mathrm{~W}$ celu kontynuowania wpisów w epoce nowożytnej dwukrotnie wzbogacono średniowieczny kodeks o nowe składki. Prawdopodobnie w latach sześćdziesiątych XVI w. dodano cztery nowe składki (ss. 123-172) , a w latach osiemdziesiątych, najpóźniej w 1590 r., jeszcze jedną składkę (ss. 173-188) ${ }^{10}$. Składki mają różną budowę: od binionów (2+2) do seksternionów (6+6). Obrazu dopełnia obecność wtórnie wszytego arkusza (ss. 117/118-119/120) i karty większego formatu (s. 131/132), a także braki: wycięta karta pomiędzy stronami 34 i 35 oraz obcięcie fragmentu karty (s. 23/24). Budowa kodeksu jest zatem heterogeniczna i nieregularna.

W rękopisie panuje wielka różnorodność paleograficzna. Spotykamy rozmaitość rąk i duktów pisarskich reprezentujących łacińskie pismo gotyckie, mieszane gotycko-humanistyczne oraz humanistyczne. Przeważa dukt kursywny; wyjątkowo napotkać można staranniejsze pismo w typie kodeksowym. Dotychczas udało się zidentyfikować w sposób pewny lub wysoce prawdopodobny autografy 27 pisarzy z lat 1432-1520. Wyniki tych badań zostaną zaprezentowane w dalszej części artykułu. Trwają badania nad autografami z kolejnych lat XVI w. W kodeksie brak jest zdobień. Czerwonym atramentem lub pismem o ozdobnym charakterze wykonano zaledwie kilka nagłówków wpisów z XVI w.

Schemat pisarski występuje sporadycznie; był wykonywany różnymi technikami, zapewne doraźnie (np. s. 1, 46-48, 119, 151/152, 157/158-167/168, 173/174). Powoduje to znaczne nieregularności w układzie tekstu na stronach. W piętnastowiecznej części kodeksu napotykamy liczne glosy z XVXVII w. Glosatorzy opatrywali uchwały tytułami i notami treściowymi. Obecność glos świadczy o długim użytkowaniu rękopisu i, pośrednio, o autorytecie, jakim obdarzano księgę uchwał jeszcze w wieku siedemnastym.

\footnotetext{
7 Za udostępnienie dokumentacji konserwatorskiej serdecznie dziękuję Pani Magister Annie Żukowskiej-Zielińskiej z Pracowni Konserwacji Papieru i Skóry Archiwum UJ. Pełny opis kodykologiczny ukaże się w przygotowywanym przeze mnie wydaniu Liber Conclusionum w serii wydawniczej Historia et Monumenta Universitatis Jagellonicae.

${ }^{8}$ Znaki wodne papieru wskazują na lata 1425-1427 (znak identyczny z zarejestrowanym w albumie Wasserzeichenkartei Piccard im Hauptstaatsarchiv Stuttgart. Findbuch 2: Die Ochsenkopf-Wasserzeichen, bearb. G. Piccard, Stuttgart 1966, Abt. XII nr 629) oraz 1429-1437 (znak identyczny z tamże, Abt. XII nr 194 oraz wariant tego znaku). Starszy znak znajduje się na kartach od strony tytułowej do s. 83/84, młodszy od s. 85/86 do 121/122.

${ }^{9}$ Pierwszy wpis w tej części kodeksu pochodzi z $1567 \mathrm{r}$. Znaki wodne odpowiadają papierowi produkowanemu od lat sześćdziesiątych XVI w. (warianty znaku zarejestrowanego w: J. Siniarska-Czaplicka, Filigrany papierni położonych na obszarze Rzeczypospolitej Polskiej od poczatku XVI do połowy XVIII wieku, nr 222, 228 — papier opatrzony tymi znakami, z herbem Abdank, uważa się za produkcję cystersów z Mogiły i/lub Mniszka z lat 1567-1590 — oraz wariant znaku nr 297 z herbem Jastrzębiec z lat ok. 1565-1618).

${ }_{10}$ Zmiana składek następuje w obrębie wpisu z $1590 \mathrm{r}$. W dodanej skadce użyto papieru opatrzonego wariantem znaku wodnego zarejestrowanego w cytowanym wyżej albumie Filigrany, nr 964 z herbem zw. Tępy Jastrzębiec, z lat ok. 1580-1600.
} 
Nie zachowała się oryginalna oprawa kodeksu. W końcu XVIII w. rękopis wtórnie oprawiono w półskórek i papier klajstrowy naklejony na tekturowe okładziny. Na przedniej okładzinie znajduje się dziewiętnastowieczna karta papierowa z sygnaturą i tytułem kodeksu: No. 63. Conclusiones Collegii Maioris. Liber ab anno 1432 ad 1591. Przednia i tylna wyklejka są współczesne oprawie.

Z uwagi na zły stan zachowania rękopis poddano konserwacji w 2010 r. W toku prac konserwatorskich, przeprowadzonych przez mgr Annę Żukowską-Zielińską z Pracowni Konserwacji Papieru i Skóry Archiwum UJ, karty zostały oczyszczone i w niezbędnym stopniu naprawione. Wymieniony został skórzany grzbiet, do którego dodano nieobecne wcześniej kapitałki, oraz górny narożnik przedniej okładziny. W celu zapewnienia lepszej ochrony bloku kodeksu przedłużono tylną okładzinę, a wnętrze zaopatrzono w karty ochronne. Do wnętrza kodeksu przeniesiono z okładki i wklejono na wyklejce górnej okładziny dawną naklejkę z tytułem: Conclusionum Collegii Maioris ab anno 1432 ad 1591 annum liber i starą sygnaturą 50.

\section{Geneza i treść rękopisu}

Omawiany rękopis $L C$ dokumentuje uchwały (conclusiones) podejmowane w latach 1432-1591 przez samorząd korporacyjny, czyli zgromadzenie ogólne kolegiatów Kolegium Królewskiego. Jest pierwszą z serii zachowanych ksiąg uchwał, których kolejne tomy obejmują lata: 1592-1681 (AUJ rkps 64), 1682-1734 (AUJ rkps 65), 1734-76 (AUJ rkps 66), 1776-80 (AUJ rkps 67).

Księgę określano najczęściej mianem Liber conclusionum (np. LC, s. 25, 28, 29 i następne). W XVI w. spotkać można odmianki tej nazwy, np. Liber conclusionum Domus (LC, s. 67; 1513 r.), lub Libellus conclusionum (LC, s. 90; 1545 r.). Spotykamy też nazwy Conclusa Domus Maioris ${ }^{11}$ i Liber actorum ${ }^{12}$. Choć na pierwszy rzut oka niepozorna, księga cieszyła się szacunkiem kolegiatów. W zapisce z 1545 r. libellus conclusionum dookreślono słowami: apud communitatem nostram autenticus. Był to wewnętrzny dokument Kolegium, drugi co do ważności po statutach. Wpisane do niej uchwały uzyskiwały walor trwałości, niezmienności, skuteczności: et hic in perpetuum robur inter conclusiones annotatum per prepositum Domus (LC, s. 52, 17 II 1507 r.).

Najstarsze wpisy w $L C$ pochodzą z początku semestru letniego 1432 r. Dotąd nie udało się odnaleźć wzmianek o istnieniu księgi zawierającej uchwały z lat wcześniejszych. Statuty Kolegium nie wspominają o księdze uchwał; mówi się tylko, że uchwała ma być przekazana przez prepozyta do realizacji (conclusionem [...] exsequi det) ${ }^{13}$. Założenie $L C$ wpisuje się być może w tendencję do porządkowania życia kolegialnego, której przejawem było zredagowanie i zapisanie dawnych statutów de novo $\mathrm{w} 1429 \mathrm{r}^{14}$ Ponieważ uchwały były interpretacją statutów i zawierały precedensy, na które następnie powoływano się w podobnych sprawach, to niewykluczone, że dostrzeżono potrzebę systematycznego ich dokumentowania.

Treść rękopisu LC odzwierciedla strukturę prawno-organizacyjną Kolegium Królewskiego. Szeroki zakres autonomii, jaką cieszyło się Kolegium, oraz korporacyjny ustrój znajdowały wyraz $\mathrm{w}$ dwustopniowo zorganizowanym samorządzie ${ }^{15}$. Po pierwsze wszyscy kolegiaci, tj. osoby dopuszczone ad mensam magistrorum, tworzyli zgromadzenie ogólne kolegiatów (convocatio generalis).

\footnotetext{
${ }_{11}$ Acta rectoralia almae Universitatis Studii Cracoviensis inde ab anno MCCCCLXIX, ed. W. Wisłocki, t. 1, Cracoviae 1893-1897 [dalej: AR], nr 2058, s. 466. Nazwa występuje w dopełniaczu: Conclusorum Domus Maioris.

12 Określenie użyte przez Marcina Biema z Olkusza w jego diariuszu — notatka z 6 II 1520 (odpis ks. Jana Fijałka z BJ Inc. 2697, rękopis bez sygnatury przechowywany w AUJ; dalej: Diariusz Marcina Biema z Olkusza).

13 Por. Statuta antiqua Collegii Maioris, nr 16, s. 8.

${ }^{14}$ Nagłówek statutów informuje: Statuta antiqua sunt de novo conscripta, et per totam communitatem Collegii Magistrorum aliqua collecta, et aliqua antiquis superaddita in quibusdam certis punctis. Por. Statuta antiqua Collegii Maioris, s. 3. Oznacza to, że niektóre statuty zostały zebrane, ujednolicone, systematycznie ułożone, być może skrócone (collecta), a inne dodane jako nowe (superaddita).

${ }^{15} \mathrm{~K}$. Ożóg, Rytm codziennego życia mistrzów uniwersytetu krakowskiego w XV i na początku XVI wieku, w: Realia życia codziennego w Europie Środkowej ze szczególnym uwzględnieniem Śląska, red. A. Barciak, Katowice-Zabrze 2011, s. 87.
} 
W kompetencjach zgromadzenia ogólnego kolegiatów leżało szeroko pojęte stanowienie, interpretowanie i realizowanie praw korporacyjnych (statuty, prawa patronatu i prezenty, prawa majątkowe). Obrady zgromadzenia odbywały się wielokrotnie w ciągu roku. Z samych statutów wynika, że obradowano co najmniej kilkanaście razy w roku. Zapisy statutowe nakazywały zwoływanie zgromadzeń w następujących okolicznościach: co semestr w celu wyboru (electio) i inauguracji rządów (institutio) nowego prepozyta ${ }^{16}$, corocznie 25 czerwca w celu zebrania opłaty przeznaczonej na zakup drewna do ogrzewania domu ${ }^{17}$, każdorazowo w celu wyboru nowego kolegiata ${ }^{18}$. Ponadto podczas zgromadzeń zwoływanych początkowo przed rozpoczęciem semestru (ante principium inchoationis studii, przypadającym nazajutrz po św. Marku - 26 kwietnia i po św. Łukaszu - 19 października ${ }^{19}$ ), a później w dzień wyboru rektora (tj. 23 kwietnia i 16 października), dokonywano głośnego, publicznego odczytania statutów kolegium w obecności wszystkich członków korporacji ${ }^{20}$. Z kolei pochodzący z 1689 r. zapis w księdze uchwał powołuje się na piam et antiquam consuetudinem zwoływania zgromadzenia kolegiatów w Wielką Środę. Podczas tego zgromadzenia kolegiaci przepraszali się wzajemnie i prosili współbraci o przebaczenie, a na znak wzajemnej miłości przekazywali sobie pocałunek pokoju $^{21}$. Czy zwyczaj ten sięgał średniowiecza - nie wiadomo, lecz nie można tego z całą pewnością wykluczyć. W pierwszym wieku istnienia Kolegium z mniejszą częstotliwością odbywały się zgromadzenia, na których wybierano skarbników Kolegium, gdyż funkcję tę sprawowano latami ${ }^{22}$. Oprócz z góry określonych terminów zwoływano zgromadzenia, gdy w życiu kolegialnym pojawiały się causae arduissimae ${ }^{23}$. Praktyka pokazuje, że przed podjęciem wiążącej uchwały obradowano bądź jednorazowo, bądź wielokrotnie, w zależności od charakteru i stopnia skomplikowania sprawy. W niektórych latach mogło odbywać się zatem kilkadziesiąt zgromadzeń.

Wspólnym mianownikiem spraw trafiających pod obrady zgromadzenia był związek instytucjonalny, personalny lub finansowy z Kolegium. Uchwały zawarte w $L C$ można uporządkować według trzech kategorii:

1. Uchwały dotyczące Kolegium jako wspólnoty tworzącej duchowe, społeczne i materialne ramy dla życia i pracy mieszkańców - profesorów. Organizacja i dyscyplina kolegialna ukierunkowane były na zapewnienie właściwych warunków dla studiów, twórczości i dydaktyki. Uchwały związane z ustrojem (zmianą lub interpretacją starych i tworzeniem nowych statutów) oraz codziennym funkcjonowaniem kolegium stanowią objętościowo niewielką, lecz ciekawą grupę wpisów, informującą o wewnętrznym życiu wspólnoty. Do tej grupy należą również uchwały odnoszące się do zarządu budynkiem i otoczeniem Kolegium.

2. Uchwały dotyczące Kolegium jako części Uniwersytetu. Liczne zależności materialne i personalne wiązały Kolegium z wydziałami, zwłaszcza filozoficznym i teologicznym, które miały w Kolegium swe siedziby, oraz z władzami ogólnouniwersyteckimi, również często w Kolegium urzędującymi. Na kartach rękopisu udokumentowano awanse, obsady katedr, urlopy od zajęć, zdarzające się niekiedy wewnątrzuniwersyteckie spory kompetencyjne czy majątkowe. Uchwały w tych sprawach przynoszą obfity materiał do historii instytucji uniwersyteckich oraz do życiorysów poszczególnych profesorów.

\footnotetext{
${ }^{16}$ Por. Statuta antiqua Collegii Maioris, nr 10, s. 6.

${ }_{17}$ Por. tamże, nr 22, s. 10.

${ }_{18}$ Por. tamże, nr 28, s. 12.

${ }^{19}$ K. Ożóg, Rytm codziennego życia, s. 82.

${ }^{20}$ Por. Statuta antiqua Collegii Maioris, nr 21, s. 10. Zapis statutowy odnosi się do starszego zwyczaju. Z kolei o drugim terminie informuje nota z przełomu XVII/XVIII w. w rękopisie statutów Kolegium, AUJ rkps 68, s. 32. O zwoływaniu w ten dzień zgromadzenia można wnioskować także z formularza okólnika i nagłówka znajdujących się w osiemnastowiecznej kopii statutów: Statuta die electionis magnifici domini rectoris cum renovatione iuramentorum legi solita (tamże, s. 63-64).

${ }^{21}$ Kraków, AUJ rkps 65, s. 168.

${ }^{22}$ Działalność skarbników Kolegium udokumentowana jest, choć z przerwami, od 1456 r. Najstarsza księga rachunkowa Kolegium Królewskiego zachowała się w rękopisie BJ 2219.

${ }^{23}$ Statuta antiqua Collegii Maioris, nr 9, s. 6. Zalecono tam prepozytowi: in arduissimis vero causis collegium consulat.
} 
3. Uchwały dotyczące Kolegium jako beneficjenta i patrona. Z upływem czasu wspólnota stała się beneficjentem rozlicznych darowizn i nadań, a zatem również patronem prebend kościelnych, właścicielem czynszów oraz nieruchomości miejskich lub ziemskich. W rezultacie w sferze zainteresowań zgromadzenia znalazły się obsady prebend i beneficjów, status prawny i materialny uposażeń, procesy sądowe związane z własnością. Administracja majątkiem, realizacja prawa patronatu, dzierżawy i spory angażowały całą wspólnotę. W rękopisie $L C$ spotkamy zatem liczne uchwały odnoszące się do obsady stanowisk kościelnych (kapituła św. Floriana, kościół, później kapituła św. Anny, altarie, probostwa, np. w Olkuszu, Zielonkach) i zarządu majątkiem kolegialnym (inwentarze dóbr, dzierżawy wsi, np. Boszczyna, Bronowic Wielkich, Trątnowic).

Drugim elementem samorządu były pochodzące z wyboru i kadencyjne władze korporacji. Swoją reprezentację zgromadzenie kolegiatów powoływało dwukrotnie w ciągu roku, na kadencje semestralne: na semestr letni w piątek poprzedzający dzień św. Jerzego (23 kwietnia), na semestr zimowy - w piątek przed dniem św. Gawła (16 października ${ }^{24}$. Wspólnocie przewodził prepozyt domu, mający do pomocy dwóch doradców oraz prowizora ${ }^{25}$. Prepozyt był zwierzchnikiem korporacji: metaforyczną głową, której górowanie nad pozostałymi członkami gwarantuje spójność ciała ${ }^{26}$. Jego szeroko pojętym zadaniem była troska o dobro wspólne w wymiarze duchowym, społecznym i materialnym. W tym celu kolegiaci przyrzekali mu posłuszeństwo, a statuty wyliczały wśród instrumentów jego władzy m.in. dyspensy, prawo sądzenia i wymierzania $\operatorname{kar}^{27}$. Zapewne dlatego w $L C$ znalazły się pojedyncze wyroki wewnątrzkolegialnego sądu sprawowanego przez prepozyta i jego dwóch doradców oraz noty o charakterze finansowo-księgowym (np. udzielane i zwracane pożyczki, spłaty rat). Do prerogatyw prepozyta zaliczało się również prawo do zwoływania zgromadzeń ogólnych kolegiatów połączone z prawem wyznaczania tematu, inicjowania, prowadzenia i podsumowywania (concludere) obrad ${ }^{28}$. W tym wymiarze uchwały zawarte w $L C$ odzwierciedlają działalność prepozytów domu lub - wyjątkowo - czynności podejmowane przez doradców lub zastępców.

\section{Tryb wnoszenia wpisów}

Posiedzenia (convocationes) zwoływał okólnikiem (schedula) prepozyt lub osoba działająca w jego imieniu. Na treść komunikatu składały się zwyczajowo: intytulacja, wskazanie terminu i miejsca obrad, informacja o celu spotkania lub przedmiocie obrad, sankcja za nieobecność, wymienienie adresatów oraz wystawcy komunikatu. Pierwszy zacytowany w LC okólnik z 29 IV 1432 r., wystawiony przez prepozyta Jana z Radochoniec, brzmiał następująco: Reverende magister! Sitis hodie hora vigesima in stuba magistrorum ad audiendam relacionem venerabilis viri domini Andree Mischka, vicarii in spiritualibus domini episcopi Cracoviensis. Detur omnibus magistris promotis et collegiatis ex parte prepositi Domus Sub debito obediencie ( $L C$, s. 2). Na przestrzeni lat udokumentowanych w $L C$ formularz okólnika nie uległ istotnym zmianom, choć zgodnie z tendencjami epoki w XVI w. stop-

\footnotetext{
${ }^{24}$ Kolejność obejmowania funkcji prepozyta i prowizora statuty Kolegium podporządkowały w kolejności powołania do Kolegium. Kolejka biegła od najmłodszego do najstarszego z kolegiatów, przy czym powołanie nowego członka wspólnoty każdorazowo przerywało ciąg. Ściśle rzecz ujmując, wspólnota nie dokonywała zatem wyboru całkowicie dowolnie, lecz zatwierdzała kandydatury wynikające $\mathrm{z}$ ordo vocationis.

${ }^{25}$ Mowa tu o prepozycie, zwanym w statutach praepositus mensae, zaś w praktyce praepositus domus, będącym zwierzchnikiem korporacji, oraz o drugim prepozycie, określanym w statutach mianem praepositus cellarii lub praepositus cervisiae, w innych źródłach niekiedy także provisor cellarii. O działalności prepozytów m. in.: K. Morawski, Historia Uniwersytetu Jagiellońskiego, t. 2, s. 422-424; K. Ożóg, Rytm codziennego życia, s. 86 n.; Z. Pietrzyk, R. Tatarzyński, Kolegia w ustroju uniwersyteckim, w: Kolegia uniwersyteckie średniowiecznej Europy. Katalog wystawy Muzeum Uniwersytetu Jagiellońskiego, Kraków 2007, s. 25 n.; K. Stopka, Życie codzienne w kolegiach uniwersyteckich średniowiecza, w: tamże, s. 104.

${ }_{26}$ Por. Statuta antiqua Collegii Maioris, nr 9, s. 5.

27 Por. tamże, nr 3, 9, 33, s. 4, 6, 14.

${ }_{28}$ Por. tamże, nr 15-16, s. 8.
} 
niowo zmieniano słownictwo i stylistykę, co prowadziło do rozbudowania komunikatu. Przykładowo, dotychczasowa stuba communis stała się hypocaustum commune (LC, s. 114), intytulację zaś okólnika wzbogacono o większą liczbą określeń honoratywnych: Egregie domine doctor ac magister venerabilis! Velit adesse tua dignitas [...] (LC, s. 91). Zresztą, zwyczaj cytowania okólnika w uchwale z czasem ustąpił miejsca praktyce jego streszczania.

Obrady prowadził i podsumowywał prepozyt zgodnie z głosami większości uczestników ${ }^{29}$. Wynik obrad zapisywany był w postaci uchwały (conclusio). Uchwały redagowano i wpisywano według formularza, który - mimo pewnych odstępstw wynikających z indywidualności prepozytów i ducha kolejnych epok - w zasadniczych punktach przetrwał przez ponad 150 lat. Trzeba niemniej zauważyć, że formularz w pełni ukształtował się dopiero w latach sześćdziesiątych XV w. (pierwszy wpis z 1464 r.). Z tego okresu pochodzi nadto większość referowanych poniżej informacji źródłowych o procedurach i praktyce dokonywania wpisów. Na wpis składały się zazwyczaj: data zwołania zgromadzenia, imię prepozyta, treść okólnika zwołującego obrady (tu także zapowiedź przedmiotu obrad), informacja o przebiegu obrad, sformułowanie uchwały w przedmiotowej sprawie, adnotacja o wysłuchaniu i akceptacji uchwały przez zgromadzenie wraz z ewentualnymi vota separata, data wpisania uchwały do księgi. Niekiedy podawano także imiona uczestników zgromadzenia. Gdy przedmiotem wpisu była uchwała w sprawie omawianej podczas kilku kolejnych zgromadzeń lub wpisywana po upływie jakiegoś czasu, na końcu wpisu umieszczano formułę z datą ostatecznego wysłuchania i przyjęcia uchwały ${ }^{30}$.

Z chwilą dokonania wpisu decyzja zgromadzenia ogólnego kolegiatów uprawomocniała się. Rozmaicie nazywano czynność, w wyniku której uchwała trafiała do księgi. W tym kontekście pojawiają się następujące czasowniki: [conclusionem] scribere ( $L C$, s. 24$)$, inscribere ( $L C$, s. 25$)$, ponere ( $L C$, s. 28$)$, reponere ( $L C$, s. 24$)$, annotare $(L C$, s. 28,43$)$, a w XVI w. także ingrossare ( $L C$, s. 75$)$. Sformułowania: sitis hodie [...] ad videndum inscribi conclusionem $(L C, \mathrm{~s} .25) \mathrm{w}$ cedule zwołującej zgromadzenie z 26 IV 1467 oraz: sitis hodie [...] ad audiendum legi conclusionem [...] et ad auscultandam et ad librum conclusionum inscribendam $(L C, \mathrm{~s}$. 35) z 2 XII 1489 r. sugerują istnienie praktyki wpisywania uchwały na oczach wszystkich zgromadzonych. Nie ulega wątpliwości, że uchwały sporządzano najpierw w wersji brulionowej, a następnie wciągano do $L C$ - czystopisu. Przytoczone cytaty jasno na to wskazują. Dodatkowego argumentu dostarczają narzędzia filologicznej krytyki tekstu. W tekstach uchwał pojawiają się niekiedy błędy charakterystyczne tylko dla kopii, zwane błędami zespolenia, jak skok „du même au même” (inaczej „skok przez homoioteleuton”) ${ }^{31}$. Ślad takiego błędu widzimy na przykład we wpisie z 15 V 1514 r. Szczęśliwie pisarz Michał z Biestrzykowa w porę zauważył przeskok od „conditione” do mającego identyczną końcówkę ,postulatione” i, skreśliwszy „ut videlicet”, opustki unikną: [...] sub tali conditione > ut videlicet $<$ expressa in sua postulatione, ut videlicet [...] $(L C, \text { s. } 68)^{32}$.

Można przypuszczać, że w kilku wypadkach wpisy do $L C$ wnoszono dwuetapowo, a cezurę stanowiły obrady zgromadzenia. Przykłady takich dwuetapowych wpisów zachowały się z czasu prepozytury Andrzeja Grzymały z Poznania (23 VII 1454 r.) oraz Michała z Biestrzykowa (15 V 1514 r.). Wpis z prepozytury Andrzeja Grzymały według kryteriów paleograficznych wyraźnie dzieli się na dwie części. Pierwsza zawiera datację, imię prepozyta oraz treść okólnika zwołującego obrady zgromadzenia. Tę część wpisu cechuje ciemniejszy kolor atramentu i pismo, które można określić jako

\footnotetext{
${ }^{29}$ Por. Statuta antiqua Collegii Maioris, nr 14-16, s. 8.

${ }^{30}$ Niekiedy kilka dni dzieliło wpis od dyskusji i podjęcia uchwały przez wspólnotę. Wskazują na to formuły używane w zapiskach, np.: ad tractandum et concludendum nuper tractatis $(L C, \mathrm{~s} .4)$. Zwłoka służyła przemyśleniu decyzji i zgłoszeniu ewentualnych poprawek lub sprzeciwów do uchwały.

${ }^{31}$ Używam terminologii zaproponowanej przez Aurelio Roncaglię w pracy Copia e corruttela, w: Principi e applicazioni di critica testuale, Roma 1975, s. 96-136, przetłumaczonej na język polski przez A. Dutkę i opublikowanej pod tytułem Kopia i znieksztatcenie w „Pamiętniku Literackim”, 85, 1994, z. 3, s. 179-190.

32 Podobnie zaklasyfikować można skreślenie w uchwale z 18 VI 1446 (LC, s. 11): [...] quod peramplius quilibet magistrorum scolarem suum proprium foveat et conservet in comodo suo, ita quod >peramplius $<$ nullus scolarium peramplius permittatur [...] (przeskok od „quod” do „quod”, a w rezultacie powtórzenie i skreślenie słowa „peramplius”).
} 
drobniejsze i niższe. Druga część opisuje przebieg obrad i przedstawia uchwałę powziętą przez kolegiatów. Wpisano ją jaśniejszym atramentem i nieco większym, bardziej okrągłym duktem. Analogicznie prezentuje się cytowany powyżej wpis z kadencji Michała z Biestrzykowa. Datację, imię prepozyta i tło sprawy będącej przedmiotem obrad, wpisano pismem staranniejszym, przestrzegając poziomych linii. Streszczenie obrad i brzmienie uchwały przedstawia się względem wcześniejszego fragmentu mniej starannie: pismo jest rozwlekłe i z większą interlinią, a linie tekstu nie zachowują poziomu. Być może należałoby włączyć do tej grupy także wpis Jana ze Słupcy z 22 V 1439 r., choć w tym wypadku różnice między częściami nie są tak ewidentne.

\section{Pisarze i opiekunowie $L C$}

Poszukując odpowiedzi na pytanie, kto wpisywał uchwały, należy w pierwszym rzędzie przyjrzeć się składowi korporacji zamieszkującej Kolegium Królewskie oraz regulacjom statutowym odnoszącym się do obrad jej zgromadzenia.

Kolegium było kilkunastoosobową wspólnotą wykładowców Uniwersytetu ${ }^{33}$, w której wyjątkowo, sporadycznie i krótkoterminowo uczestniczyły osoby spoza grona profesorskiego. Prawo uczestnictwa w zgromadzeniach oraz czynne i bierne prawo wyboru władz przysługiwało z zasady wszystkim kolegiatom, tj. osobom przyjętym ad mensam magistrorum. I choć w XV w. znamy kilka osób spoza grona profesorskiego, którym wspólnota przyznała pełne prawa ${ }^{34}$, to z przeglądu listy prepozytów Kolegium wynika, że w okresie, który obejmuje analizowany rękopis $L C$, funkcję tę sprawowali sami profesorowie ${ }^{35}$. W dotychczasowych badaniach nie spotkałam się z sytuacją, aby prepozyturę objął ktoś z grona dopuszczonych ad mensam, lecz nie będący profesorem ${ }^{36}$.

Koledzy, stojąc wobec całej wspólnoty, składali na ręce prepozyta przysięgę posłuszeństwa, przestrzegania statutów i uchwał, a także zachowania w tajemnicy treści obrad wspólnoty odbywanych per modum secretorum aut capitulariter. Złamanie tajemnicy obrad sankcjonowane było karą pieniężną lub, w wypadku recydywy, co najmniej wykluczeniem z obrad ${ }^{37}$. O tym, że dbano o przestrzeganie statutowych zapisów, świadczy proces Andrzeja Tropera w sierpniu 1563 r., którego za wynoszenie wewnętrznych spraw na forum publiczne wspólnota ukarała wydaleniem z Kolegium, łaskawie wszak zamieniając ten surowy wyrok na karę pieniężną ( $L C$, s. 114-116). Z tego powodu tym trudniej wyobrazić sobie, aby uchwały do księgi, będącej wewnętrznym dokumentem Kolegium, wpisywały osoby spoza wspólnoty. Można więc przyjąć, że wpisy do $L C$ były wnoszone przez samych kolegiatów.

\footnotetext{
${ }^{33}$ Na podstawie źródła z początku XVI w. A. Włodarek szacował liczebność wspólnoty na ok. 19-21 profesorów (A. Włodarek, Architektura, s. 98, 132). Dane źródłowe na temat liczby kolegiatów są rzadkie. W 1468 r. wzmiankowano 18 profesorów: [...] omnesque doctores et magistri Domus tunc in numero decem octo (Kraków, BJ rkps 2219, k. 16v).

${ }^{34}$ Byli to m.in. Otto, syn Marcisza z Tołochowa, scholastyk krakowski (zm. w 1412 r.), Piotr, biskup Nitry (po 1403 r.), Gabriel Tęczyński z Tęczyna (ok. 1471-1472 r.). Wątpliwe, aby do tego grona należał książę litewski Jan Gasztołd (ok. 14881490/1491 r.), o którym napisano, że został przyjęty do Kolegium (in Collegium receptus fuerat), lecz nie ma mowy o dopuszczeniu go ad mensam magistrorum. Por. BJ rkps 2219, k. 22v, 23r, 24r, 40v, 43r; M. Kowalczyk, Krakowskie mowy uniwersyteckie z pierwszej połowy XV wieku, Wrocław 1970, s. 121, 181; Z. Kozłowska-Budkowa, Odnowienie jagiellońskie, s. 77; K. Morawski, Historia Uniwersytetu Jagiellońskiego, t. 2, s. 65, 157.

${ }_{35}$ Pierwszego i jak dotąd jedynego zestawienia prepozytów z lat 1457-1522 dokonał Jerzy Zathey na podstawie księgi rachunków Kolegium Królewskiego (BJ rkps 2219): J. Zathey, Biblioteka Jagiellońska w latach 1364-1492, w: J. Zathey, A. Lewicka-Kamińska, L. Hajdukiewicz, Historia Biblioteki Jagiellońskiej, t. 1: 1364-1775, Kraków 1966, s. 41 n. Zestawienie to, oparte na jednym źródle i bez wystarczającego, jak się wydaje, rozpoznania instytucji prepozytur i Kolegium, można obecnie znacząco rozszerzyć chronologicznie i osobowo, a w niektórych miejscach także poprawić. W przygotowaniu jest moja praca na temat prepozytów Kolegium Większego w XV i na początku XVI w.

${ }^{36}$ W 1471 r. w rachunkach Kolegium (BJ rkps 2219, k. 22v, 23r, 24r) zanotowano, że od pełnienia funkcji prepozyta wykupił się Gabriel z Tęczyna, syn kasztelana krakowskiego Jana, przyjęty na początku tego roku ad mensam magistrorum. Jesienią wpłacił 4 grzywny racione prepositure redemte. $\mathrm{Z}$ tej sumy trzy grzywny trafiły do prepozyta urzędującego w zamian za Tęczyńskiego, a jedna do skarbca Kolegium.

${ }^{37}$ Statuta antiqua Collegii Maioris, nr 13, s. 7 n.
} 
Drugiej grupy argumentów dostarcza lektura treści uchwał, które dokumentują szereg praw i regulacji zwyczajowych. Argument o pierwszorzędnym znaczeniu dla badanego tematu znajduje się w zapisce z 1475 r. $(L C$, s. 28). Latem tego roku mistrz Marcin z Krakowa, zwany Łysym, zaprotestował przeciw dotyczącej go uchwale zgromadzenia Kolegium, podnosząc zastrzeżenia proceduralne ${ }^{38}$. Kwestionował m.in. fakt wpisania uchwały przez nieodpowiednią osobę. Pisarzem nie był bowiem ani prepozyt, ani osoba wskazana przez wspólnotę: qui scripsit eam [uchwałę — przyp. DWZ] non fuit prepositus nec per communitatem fuit sibi comissum. Pozostałe oprotestowane uchybienia to zmiana treści uchwały (in clausulis certis fuit variata) oraz wpisanie jej bez zgody i uprzedniego wysłuchania treści przez wspólnotę (sine consensu communitatis fuit scripta, non premissa auscultacione communitatis). Zarzuty musiały być zasadne, skoro wspólnota zdecydowała o wykreśleniu uchwały i ponownym rozpatrzeniu sprawy. Ujmując pozytywnie treść skargi mistrza Marcina, można łatwo zrekonstruować procedurę wnoszenia wpisów do $L C$. Po pierwsze, uchwała musiała być zredagowana zgodnie z wynikiem obrad. Po drugie, wpisanie do $L C$ poprzedzone było odczytaniem uchwały na forum (auscultatio communitatis / per communitatem) oraz wyrażeniem wspólnotowej zgody na dokonanie wpisu (consensus communitatis). Po trzecie, samego aktu wniesienia wpisu do księgi dokonywał prepozyt lub osoba wyznaczona przez wspólnotę. Analogiczne sformułowanie o powierzeniu wpisu prepozytowi przynosi również uchwała z 17 II 1507 r.: sic est conclusum et ad inscribendum inter conclusiones preposito commissum ( $L C, \mathrm{~s} .52)$.

Potwierdzeniem roli prepozyta w dokonywaniu wpisów jest formuła subskrypcyjna scriptum per $m e$, znajdująca się w trzech piętnastowiecznych zapiskach (nr 20,21, 22), przy czym pierwsza z nich wskazuje na wiceprepozyta ${ }^{39}$, a dwie kolejne na prepozyta. Znacznie częściej (22 razy) tę lub analogiczną formułę manu propria spotyka się w zapiskach szesnastowiecznych (począwszy od roku 1502). W świetle innych obserwacji dotyczących prowadzenia $L C$ zasadne wydaje się przypuszczenie, że w XVI w. zwyczaj wpisywania uchwał przez prepozytów był kontynuowany, a nie radykalnie zmieniony.

Wiele faktów wskazuje na to, że rękopis $L C$ pozostawał pod pieczą prepozyta domu. Za taką hipotezą przemawiają nie tylko przytoczone powyżej argumenty łączące dokonywanie wpisów z prepozytami. O tym, że co najmniej na początku XVI w. dwa najważniejsze dla Kolegium teksty normatywne, tj. statuty oraz $L C$, znajdowały się w rękach prepozyta, informuje nas zapis w aktach sądu rektorskiego z 1 XII 1505 r. Ówczesny prepozyt Kolegium, Wojciech ze Swodziszowic, wniósł tego dnia sprawę przeciwko Maciejowi z Szydłowa o przejęcie ksiąg statutów i konkluzji przemocą z rąk urzędującego prepozyta (occasione recepcionis violente ,Statutorum” et „Conclusorum Domus Maioris” de manibus [...] prepositi). Z kolei Maciej z Szydłowa oskarżał Wojciecha i jego stronników o bezprawne pozbawienie go prepozytury (spoliatio prepositure), której pełnienie, jego zdaniem, miało przypadać na bieżący semestr ${ }^{40}$. Kontekst sprawy sugeruje, że obydwie urzędowe księgi Kolegium Większego: „Statuta” i „Conclusiones” były postrzegane jako atrybuty władzy prepozyta — i rzeczywiście mogły nimi być. Analogicznie do rektora, któremu podczas inauguracji rządów wręczano pierścień, pieczęć, metrykę i statuty uniwersyteckie ${ }^{41}$, prepozyt otrzymywał pieczęć oraz księgę statutów i księgę uchwał

\footnotetext{
38 Wzmiankę o tej sprawie podał J. Wolny w biogramie Macieja z Szydłowa w PSB, t. 19, s. 37.

39 Mianem wiceprepozyta określano w źródłach osoby, które zastępowały prepozyta przez dłuższy czas, nawet przez całą kadencję. Analogicznie w zastępstwie rektora funkcjonował wicerektor.

$40 A R$, t. 1, nr 2058, s. 466 n.

${ }^{41}$ Metryka Uniwersytetu Krakowskiego z lat 1400-1508 [dalej: Metryka], t. 1: Tekst, wyd. A. Gąsiorowski, T. Jurek, I. Skierska, przy współpr. R. Grzesika, Kraków 2004, s. XXIII, XXXII. Słowa: Hic praesento vobis annulum aureum, sigilla Universitatis. Hic praesento vobis Matriculam. Item, librum Statutorum. Alia autem, quae vobis tradere debeo, postea vobis tradentur wypowiadał ustępujący rektor po przyjęciu przysięgi od swego następcy. Formuła pochodzi z najstarszych statutów uniwersyteckich i zachowała się w oblacie statutów dokonanej w 1650 r. z inicjatywy Gabriela Ochockiego (AUJ rkps 15, s. 9). Tekst wydał J. Szujski, Statuta Uniwersytetu Krakowskiego, ADLOP, 2, 1882 , s. 403.
} 
Kolegium. Tak było z pewnością w XVII w. ${ }^{42}$ Przytoczony zapis z akt sądu rektorskiego oraz wiedza o konserwatyzmie obyczajów uniwersyteckich skłaniają do przypuszczenia, że zwyczaj ten sięgał początków życia kolegialnego. Niewątpliwie trwał do ostatnich lat istnienia uniwersytetu w jego średniowiecznym kształcie, gdyż jeszcze w 1774 r. Józef Alojzy Putanowicz pisał o prepozycie Kolegium: „Powinność iego iest, gdy potrzeba, składać convocationes Doktorow y Professorow, resultata ex Convocationibus w Xięgę wpisywać”43.

Zebrane przesłanki źródłowe prowadzą do wniosku, że odpowiedzialność za księgę i wpisywanie uchwał spoczywała przede wszystkim na prepozycie. W jego prawa wchodził również wiceprepozyt, czyli oficjalny zastępca. Wspólnota mogła też jednorazowo wyznaczyć kogoś dla dokonania wpisu uchwały. W każdym wypadku była to osoba należąca do grona członków Kolegium. Uzasadnione wydaje się zatem zawężenie grona osób piszących w $L C$ do kręgu krakowskich profesorów — kolegiatów Kolegium Królewskiego.

\section{Autografy piętnastowiecznych profesorów krakowskich. Katalog}

Przedmiotem badań mających na celu identyfikację autografów były wpisy w $L C \mathrm{z}$ lat 1432-1520. Katalog autografów podzielony został na dwie części. W części A ujęto autografy poświadczone formułami subskrypcyjnymi, co do których nie ma wątpliwości, że wyszły spod pióra osób je sygnujących. We wszystkich wpisach poświadczonych formułą subskrypcyjną scriptum per me lub scriptum per manus mamy do czynienia z autografami krakowskich profesorów sztuk wyzwolonych lub teologii. Na osiem poświadczonych autografów, siedem wpisali aktualnie urzędujący prepozyci: Jan z Raciborska (jako wiceprepozyt, nr 2), Jan ze Stobnicy (nr 3), Leonard z Dobczyc (nr 4), Marcin z Szamotuł (nr 5), Michał z Wrocławia (nr 6), Stanisław z Kleparza ( $\mathrm{nr} 7$ ), Wojciech z Parlina (nr 8), a tylko jeden wyszedł spod pióra kolegiata nie będącego wówczas prepozytem - Jana z Oświęcimia zw. Beberem (nr 1).

W części B listy umieszczono autografy nie posiadające formuły subskrypcyjnej. Wymagały one innego podejścia badawczego. Identyfikacji tych autografów dokonano, porównując wpisy w $L C$ z poświadczonymi autografami krakowskich profesorów w innych rękopisach oraz starodrukach Archiwum Uniwersytetu Jagiellońskiego i Biblioteki Jagiellońskiej w Krakowie. Wiadomości o zachowanych kolofonach i subskrypcjach zaczerpnięto przede wszystkim z katalogów, nadto publikacji dotyczących rękopisów Biblioteki Jagiellońskiej, opracowań poszczególnych autorów oraz z autopsji wybranych rękopisów ${ }^{44}$. W rzadkich wypadkach, gdy brak jest poświadczonych autografów profesora-pisarza, odniesieniem były rękopisy i/lub starodruki z udokumentowanym pochodzeniem z biblioteki danej osoby (tzn. takie, w których znalazły się zapiski własnościowe i legacyjne). Porównaniu podlegały, po pierwsze, szczegóły pisma: kształty poszczególnych liter i cyfr, połączenia liter, znaki skróceń, znaki interpunkcyjne, zakończenia słów, linii, a po drugie, kompozycja tekstu: odstępy między wyrazami i liniami pisma, rozplanowanie tekstu na stronie.

\footnotetext{
${ }^{42}$ W księdze uchwał z XVII w. znajdują się wzmianki o ceremonii installatio, inaczej investitio prepozyta. Wręczano mu wówczas atrybuty władzy wymienione w spisie (iuxta inventarium). Przykład takiego inwentarza znajduje się w rękopisie AUJ 65, s. 48 (1684 r.).

43 J.A. Putanowicz, Stan wewnętrzny y zewnętrzny Studii generalis Universitatis Cracoviensis, [Kraków] 1774, k. D 1 r.

${ }^{44} \mathrm{~W}$ toku kwerendy wykorzystano dane o autografach pochodzące m. in. z następujących publikacji: Catalogus codicum manuscriptorum medii aevi Latinorum, qui in Bibliotheca Jagellonica Cracoviae asservantur [dalej: Catalogus], t. 1-5, Wratislaviae 1980-1993, t. 6-10, Cracoviae 1996-2012; M. Kowalczyk, Krakowskie mowy uniwersyteckie; M. Kowalczyk, Colligite fragmenta, ne pereant... Studia z dziejów Uniwersytetu Krakowskiego w średniowieczu, Kraków 2010; Metryka, t. 1: Tekst, t. 2: Indeksy; Najstarsza księga promocji Wydziatu Sztuk Uniwersytetu Krakowskiego z lat 1402-1541, wyd. A. Gąsiorowski, T. Jurek, I. Skierska, Warszawa 2011; G. Rosińska, Scientific Writings and Astronomical Tables in Cracow. A Census of Manuscript Sources (XIV ${ }^{\mathrm{h}}-X V I^{\mathrm{th}}$ Centuries), Wrocław 1984; W. Wisłocki, Incunabula typographica Bibliothecae Universitatis Jagellonicae Cracoviensis inde ab inventa arte imprimendi usque ad a. 1500, Cracoviae 1900; tenże, Katalog rękopisów Biblioteki Uniwersytetu Jagiellońskiego, Kraków 1877-1881; Z. Włodek, Z dziejów filozofii i teologii na Uniwersytecie Krakowskim w XV wieku. Sylwetki, teksty, studia [dalej: Z dziejów filozofii i teologii], Kraków 2011.
} 
Ekspertyza pisma opierała się na ocenie wzrokowej, bez stosowania wymiernych metod kwantytatywnych (np. badania modułu pisma, kąta nachylenia). Badania porównawcze napotkały na trudność sygnalizowaną już przez wielu badaczy, a polegającą na występowaniu obok siebie różnych charakterów pisma tej samej osoby, modyfikowanego stosownie do rodzaju tekstu (brulion - czystopis, tekst główny — nagłówek), jego przeznaczenia (prywatne — publiczne, księga urzędowa tekst naukowy), nowych wzorców, mód, wpływów i gustów. Zjawisko to nazwano w literaturze wielopostaciowością pisma (polymorphisme de l'écriture) ${ }^{45}$. Przykładowo, w $L C$ możemy mieć do czynienia tylko z takim rodzajem pisma, jakim osoba posługiwała się w księgach urzędowych; pismo kodeksowe będzie od niego zasadniczo różne, choć nie pozbawione pewnych podobieństw, niekiedy w niuansach, gdyż pomimo różnic pismo może ujawniać te same tendencje. Drugi przykład to posługiwanie się pismem o rozmaitych krojach w różnych okresach życia. Dobrym przykładem jest tu pismo Andrzeja Grzymały z Poznania, który w zestawionych przeze mnie kodeksach używał przynajmniej dwóch wzorów pisma ${ }^{46}$. Charakter pisma w $L C$ odpowiada tylko jednemu z nich, choć nie pozostaje bez związków z drugim. Za dowód uznawałam w tym wypadku zbieżność wielu (subiektywnie ocenionych) podobieństw. Uzyskane wnioski oceniam jako wysoce prawdopodobne, niemniej bez gwarancji pewności. Świadomość tego rodzaju ograniczeń musi towarzyszyć interpretacji wyników badań i ewentualnemu ich wykorzystywaniu.

Lista autografów jest dwuczęściowa (A-B). Każdą część ułożono alfabetycznie według imion profesorów-kolegiatów piszących w $L C$. Przyjęto następujący formularz opisu autografu: imię i miejscowość pochodzenia pisarza, umiejscowienie autografu w rękopisie $L C$ (nr strony), datacja autografu (ewentualnie data akcji prawnej, do której odnosi się zapiska) wraz z imieniem urzędującego prepozyta (jeśli jest znane), wystąpienia tego samego pisma w innych rękopisach (w wypadku autografów nie potwierdzonych formułą subskrypcyjną, których identyfikacji dokonano przez porównanie z innymi rękopisami), najważniejsze fakty z kariery uniwersyteckiej ${ }^{47}$.

\section{W notach biograficznych zastosowano następujące skróty:}

e

h

ADLOP

AR I

AUJ

CDUJ
- semestr letni

- semestr zimowy

— „Archiwum do Dziejów Literatury i Oświaty w Polsce”

- Acta rectoralia almae Universitatis studii Cracoviensis inde ab Anno MCCCCLXIX, ed. W. Wisłocki, t. 1, Cracoviae 1893-1897

- Kraków, Archiwum Uniwersytetu Jagiellońskiego

- Codex diplomaticus Universitatis Studii Generalis Cracoviensis. Continet privilegia et documenta, quae res gestas Academiae eiusque beneficia illustrant, Partes I-V, ed. I. Pauli, Cracoviae 1870-1900

\footnotetext{
${ }^{45}$ G. Ouy, Autographes d'auteurs français des XIVe et XVe siècles: leur utilité pour l'histoire intellectuelle, St. Źród1., 28, 1983, s. 69-103; F. Gasparri, Authenticité des autographes, w: Gli autografi medievali. Problemi paleografici e filologici. Atti del convegno di studio della Fondazione Ezio Franceschini, Erice, 25 settembre - 2 ottobre 1990, a cura di P. Chiesa, L. Pinelli, Spoleto 1994, s. 3-22, zwłaszcza s. 15-18, 21 n.; J. Słowiński, Dawna sztuka pisania a możliwości identyfikacji pisma, „Res Historica”, 3, 1998, s. 211-219.

${ }^{46}$ Kłopot z identyfikacją jego pisma sygnalizował J. Słowiński, Pismo humanistyczne w kręgu piętnastowiecznej Akademii Krakowskiej, St. Źródł., 35, 1994, s. 106-110.

${ }^{47}$ Ponieważ większości osób znajdujących się na liście poświęcono już opracowania lub noty biograficzne, w punkcie „Kariera uniwersytecka" podaję podstawowe wiadomości o wykształceniu, stopniach naukowych, działalności uniwersyteckiej i funkcjonowaniu we wspólnocie Kolegium Królewskiego, pomijając wiadomości o beneficjach lub zaangażowaniu poza Uniwersytetem. Wiadomości z opracowań starałam się zweryfikować w oparciu o podstawę źródłową i wiedzę na temat funkcjonowania Uniwersytetu Krakowskiego; stąd pojawiające się niekiedy rozbieżności. W każdym wypadku podaję odsyłacze tylko do wykorzystanej literatury.
} 
CUC

Diariusz Marcina Biema z Olkusza

LD

M I

NKP

Barycz, Historia UJ

Bukowski, Rachunki 1

Bukowski, Rachunki 2

Filozofia w Polsce

Gąsiorowski, Bylina i inni

Kowalczyk, Wypominki

Markowski, $D z W T$

PoczetR

Statuta Bursae Longini

Wisłocki, Incunabula
- Conclusiones Universitatis Cracoviensis ab anno 1441 ad annum 1589, wyd. H. Barycz, Kraków 1933

- odpis ks. Jana Fijałka z BJ Inc. 2697, rękopis bez sygnatury przechowywany w Archiwum Uniwersytetu Jagielońskiego w Krakowie

- Liber diligentiarum Facultatis Artisticae Universitatis Cracoviensis, wyd. W. Wisłocki, „Archiwum do Dziejów Literatury i Oświaty w Polsce”, 4, 1886

- Metryka Uniwersytetu Krakowskiego z lat 1400-1508, t. 1: Tekst, t. 2: Indeksy, wyd. A. Gąsiorowski, T. Jurek, I. Skierska, przy współpr. R. Grzesika, Kraków 2004

- Najstarsza księga promocji Wydziatu Sztuk Uniwersytetu Krakowskiego z lat 1402-1541, wyd. A. Gąsiorowski, T. Jurek, I. Skierska, Warszawa 2011

- H. Barycz, Historia Uniwersytetu Jagiellońskiego w epoce humanizmu, Kraków 1935

- W. Bukowski, Z najstarszych dziejów skarbowości Uniwersytetu Krakowskiego. Rachunki dziekanów Wydziału Sztuk z lat 1458-1470, w: Fontes et historia. Prace dedykowane Antoniemu Gąsiorowskiemu, red. T. Jurek i I. Skierska, Poznań 2007, s. 7-29

- W. Bukowski, Z najstarszych dziejów skarbowości Uniwersytetu Krakowskiego. Rachunki prokuratorów generalnych za lata 1458-1490, w: Miasta ludzie — instytucje - znaki. Księga jubileuszowa ofiarowana Profesor Bożenie Wyrozumskiej w 75. rocznice urodzin, pod red. Z. Piecha, Kraków 2008, s. 653713

- Filozofia w Polsce. Stownik pisarzy, Wrocław 1971

- Antoni Gąsiorowski, Bylina i inni. Dziekani Wydziału Sztuk krakowskiego uniwersytetu w XV wieku, w: Ludzie - Kościót - Wierzenia. Studia z dziejów kultury i społeczeństwa Europy Środkowej (średniowiecze - wczesna epoka nowożytna), Warszawa 2001, s. 523-537

- M. Kowalczyk, Wypominki Uniwersytetu Krakowskiego z lat 1431/1432, 1453 i 1458, „Studia Warmińskie”, 9 (1972), s. 523-534, [przedruk w:] M. Kowalczyk, Colligite fragmenta, ne pereant... Studia z dziejów Uniwersytetu Krakowskiego w średniowieczu, Kraków 2010, s. 187-198

- M. Markowski, Dzieje Wydziatu Teologii Uniwersytetu Krakowskiego w latach 1397-1525, Kraków 1996

- Z. Pietrzyk, Poczet rektorów Uniwersytetu Jagiellońskiego 1400-2000, Kraków 2000

- Statuta Bursae Longini seu Canonistarum ex a. 1485, w: P. Burzyński, Nauka prawa na Uniwersytecie Krakowskim w ciagu czasu od r. 1364 do r. 1795, „Czasopismo Poświęcone Prawu i Umiejętnościom Politycznym”, 2, 1864, z. 5, s. LXIX-XCV

- W. Wisłocki, Incunabula typographica Bibliothecae Universitatis Jagellonicae Cracoviensis inde ab inventa arte imprimendi usque ad a. 1500, Cracoviae 1900

Rękopisy cytowane są konsekwentnie według sygnatur. Trzy często powoływane rękopisy to najstarsze urzędowe księgi Uniwersytetu Krakowskiego, które noszą własne tytuły:

BJ rkps 249 - Liber diligentiarum Facultatis Artium (1487-1563)

BJ rkps 258 - Metryka Uniwersytetu Krakowskiego (1400-1508)

BJ rkps 263 - Księga promocji Wydziału Sztuk(1402-1541)

Rozwiązania niejednoznacznych skrótów umieszczono w nawiasach ostrych $<>$. 


\section{A. Autografy potwierdzone w $L C$}

\section{Jan Beber z Oświęcimia}

autografy w LC: s. 119: [...] scriptum per me magistrum Johannem de Oszwyanczim [...]. daty: 18 XI 1476, prepozyt: Klemens z Gębic.

inne przykłady autografów: AUJ rkps 377a, s. 2-3 (reprodukcja stron w: Bukowski, Rachunki 2, s. 667); BJ rkps 258, s. 302-30748 (reprodukcja s. 306 z autografem Jana w wydaniu Metryki, t. 1, s. 410); BJ rkps 263 , k. 24va-vb ${ }^{49}, 28 \mathrm{r}$ (wpisy dodane między kolumnami i u dołu strony), 28va-vb (dziekanat Stanisława z Szadka), 29va-vb (dziekanat Jana z Toszka), 30va.

kariera uniwersytecka: student 1440e, bakałarz 1446, magister sztuk 1449, bakałarz biblijny 1468/1469, bakałarz format teologii 1473, doktor teologii 1476, profesor na Wydziale Teologii 1477, prepozyt Kolegium Większego 1461e, długoletni skarbnik Kolegium 1465-1479, kanonik kolegiaty św. Floriana 1470, tamże kustosz 1479, czterokrotny dziekan Wydziału Sztuk 1456h, 1466h, 1467e, 1474h, dziekan Wydziau teologii 1475h, 1481h, prokurator Uniwersytetu 1459-1463, konsyliarz rektora 1473, 1478, 1482, wicerektor 1478, trzykrotny rektor Uniwersytetu 1479e-1480e, zm. 10 VIII 1482 (BJ rkps 2219, k. 5v, 8r-35r; M I 40e/041; NKP 46/6B [ewentualnie 46/22B], 49/8M; Bukowski, Rachunki 2, s. 674, przyp. 7 - tam wiadomości o karierze pozauniwersyteckiej i dalsza literatura; Bukowski, Rachunki 1, s. 26 n., przyp. 14).

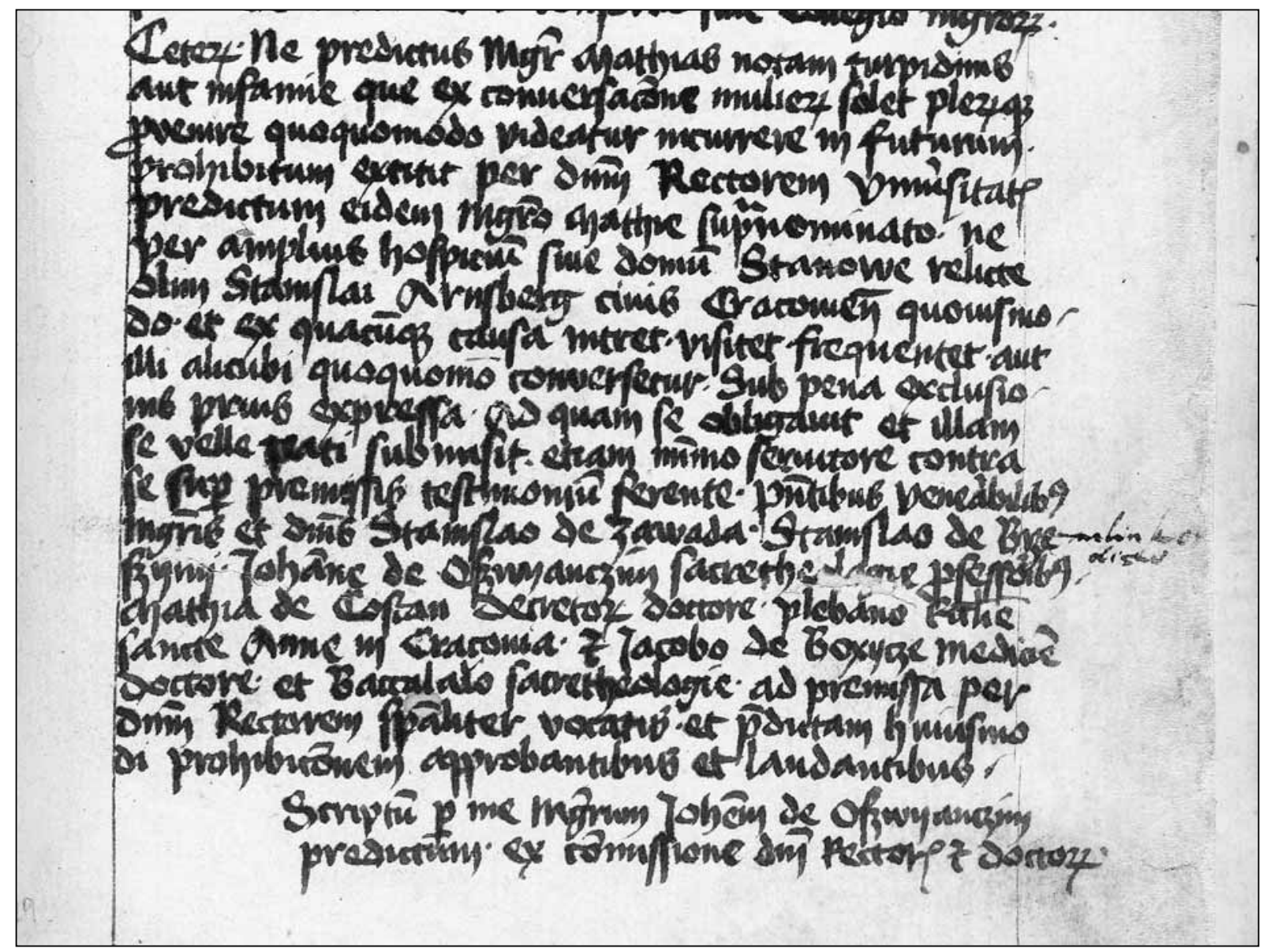

Il. 1: Autograf Jana Bebera z Oświęcimia (LC, s. 119)

\footnotetext{
48 Autograf zidentyfikowany przez Wydawców, Metryka, t. 1, s. 403, 405, 408.

49 Autograf zidentyfikowany przez Wydawców, Najstarsza księga promocji, s. XVI.
} 


\section{Jan z Raciborska}

autografy w LC: s. 10: [...] per me magistrum Johannem de Raczÿborszko protunc viceprepositum domus Collegii Artistarum.

daty: 7 VIII 1444, prepozyt: wiceprepozyt Jan z Raciborska.

inne przykłady autografów: nieznane.

kariera uniwersytecka: student 1425, bakałarz 1429, magister sztuk 1433, profesor na katedrze matematyki i astronomii fundacji Jana Stobnera 1439, wiceprepozyt Kolegium Królewskiego 1444e, bakałarz biblijny ok. 1444-1445, dwukrotny dziekan Wydziału Sztuk 1443h, 1444e, zm. najpóźniej w 1453 (LC, s. 10; M I 25/097; NKP 29/42B, 33/30M; Gąsiorowski, Bylina i inni, s. 531; Markowski, DzWT, s. 163; Kowalczyk, Wypominki, s. 532 [196]).

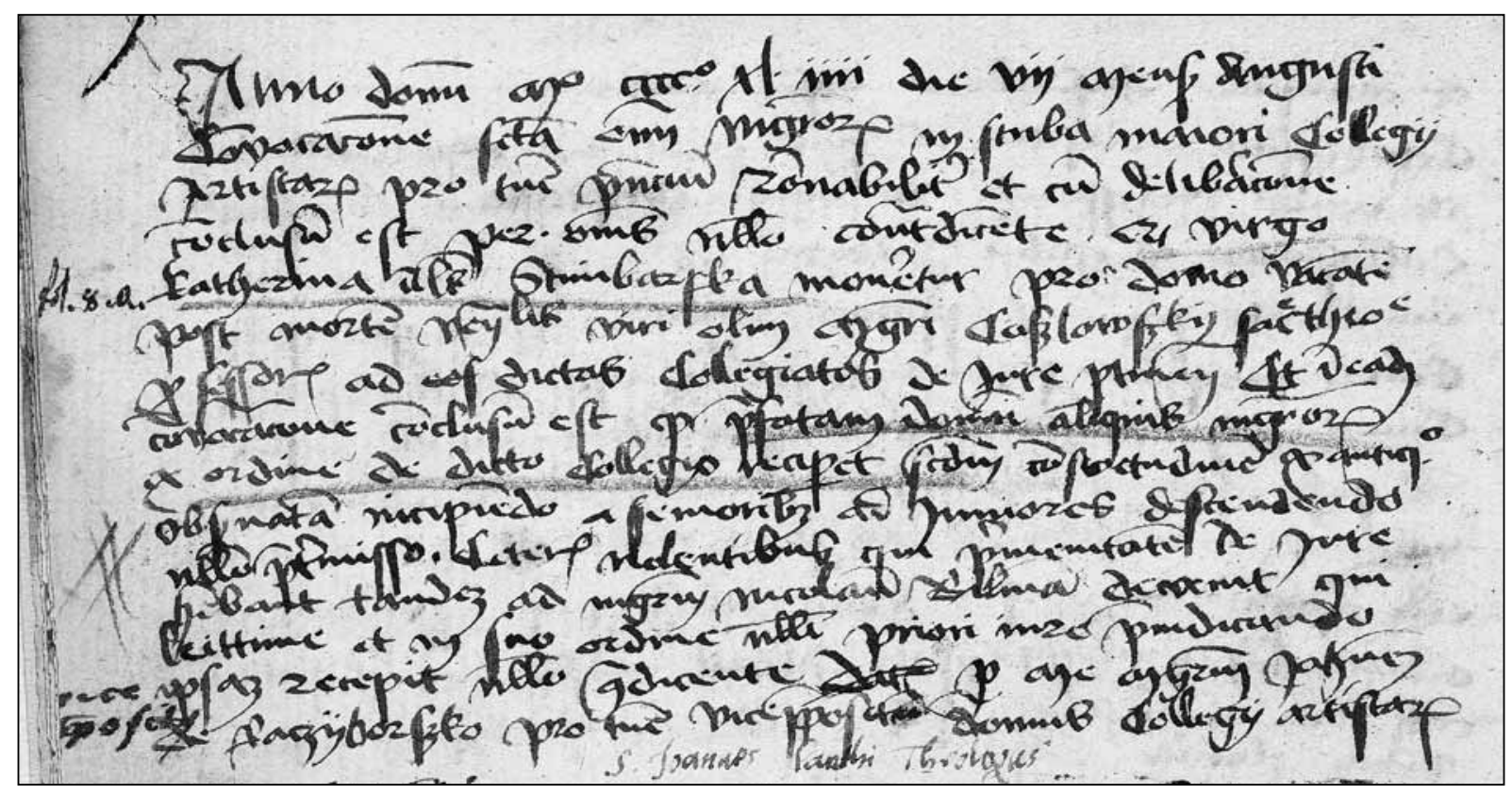

Il. 2: Autograf Jana z Raciborska ( $L C$, s. 10$)$ 


\section{Jan ze Stobnicy}

autografy w LC: s. 60: [...] in prepositura magistri Joannis de Stobnicza tunc presente, cuius et propria manu est hic scripta.

daty: 17 III 1509, prepozyt: Jan ze Stobnicy.

inne przykłady autografów: BJ rkps 263, k. 63vb-64ra; BJ rkps 2219, k. 103r-105v, 110r-114v.

kariera uniwersytecka: student 1490e, bakałarz 1494, magister sztuk wyzwolonych 1498, kolegiat Kolegium Mniejszego 1504-1506, do Kolegium Większego wszedł między 17 a 25 II 1507, prepozyt Kolegium Większego 1508h, skarbnik Kolegium 1512-1514, dwukrotny dziekan Wydziału Sztuk 1507h, 1513h, w zakonie bernardynów od marca 1514, zm. 1530 (LC, s. 60; BJ rkps 2219, k. 66r, 103r-105v, 110r-114v; Diariusz Marcina Biema z Olkusza; M I 90e/053; NKP 94/94B, 98/1M; PSB 10, s. 480 n.).

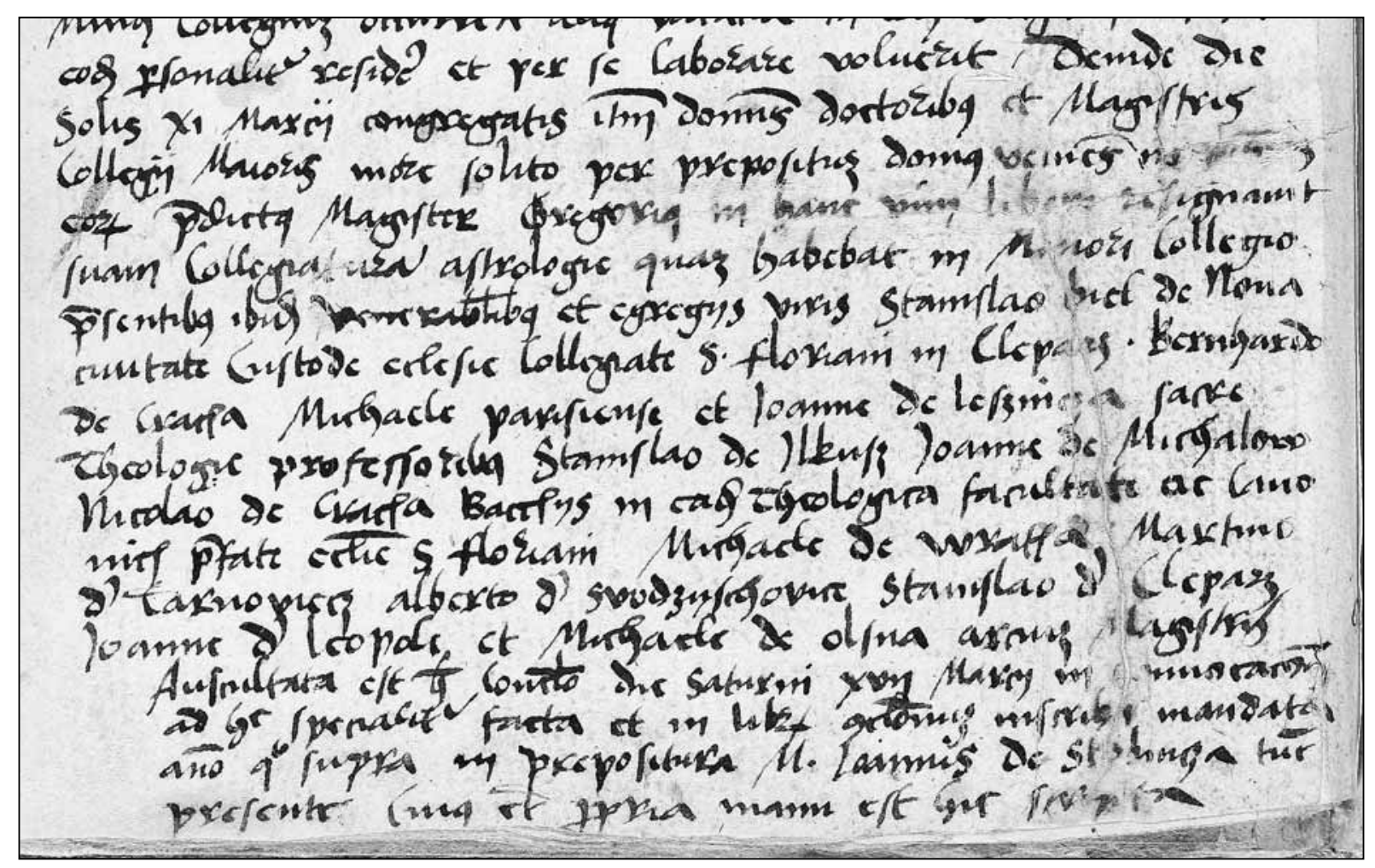

Il. 3: Autograf Jana ze Stobnicy $(L C$, s. 60$)$ 


\section{Leonard z Dobczyc}

autografy w LC: s. 43: Magister Leonardus de Dopschycze in sua prepositura, quam gessit anno 1502 in commutacione estivali, annotavit manu propria; s. 48-53: [s. 51] [...] per me magistrum Leonardum de Dopschicze, prepositum domus protunc existentem, manu propria.

daty: 1502 [między 22 IV a 14 X], prepozyt: Leonard z Dobczyc; 30 I, 17 II, 9 III 1507, prepozyt: Leonard z Dobczyc.

inne przykłady autografów: AUJ rkps 57, s. 86-87; BJ rkps 249, k. 30v-31r; reprodukcja autografu z rękopisu BJ rkps 3225, s. 204-205, w: G. Rosińska, Scientific Writings, il. 18.

kariera uniwersytecka: student 1483h, bakałarz 1486, magister sztuk 1489, bakałarz dekretów 1501, bakałarz teologii 1506, kolegiat Kolegium Mniejszego 1497, w Kolegium Większym od 29 X 1501, prepozyt Kolegium Większego 1502e, 1506h, prowizor Kolegium Większego 1504e, dziekan Wydziału Sztuk 1501e, 1506h, zm. 20 I 1508 (LC, s. 43, 48-51; BJ rkps 2219, k. 50r, 63r, 90v; M I 83h/312; NKP 86/53B, 89/17M; PSB 17, s. 71 n.; Markowski, DzWT, s. 212).

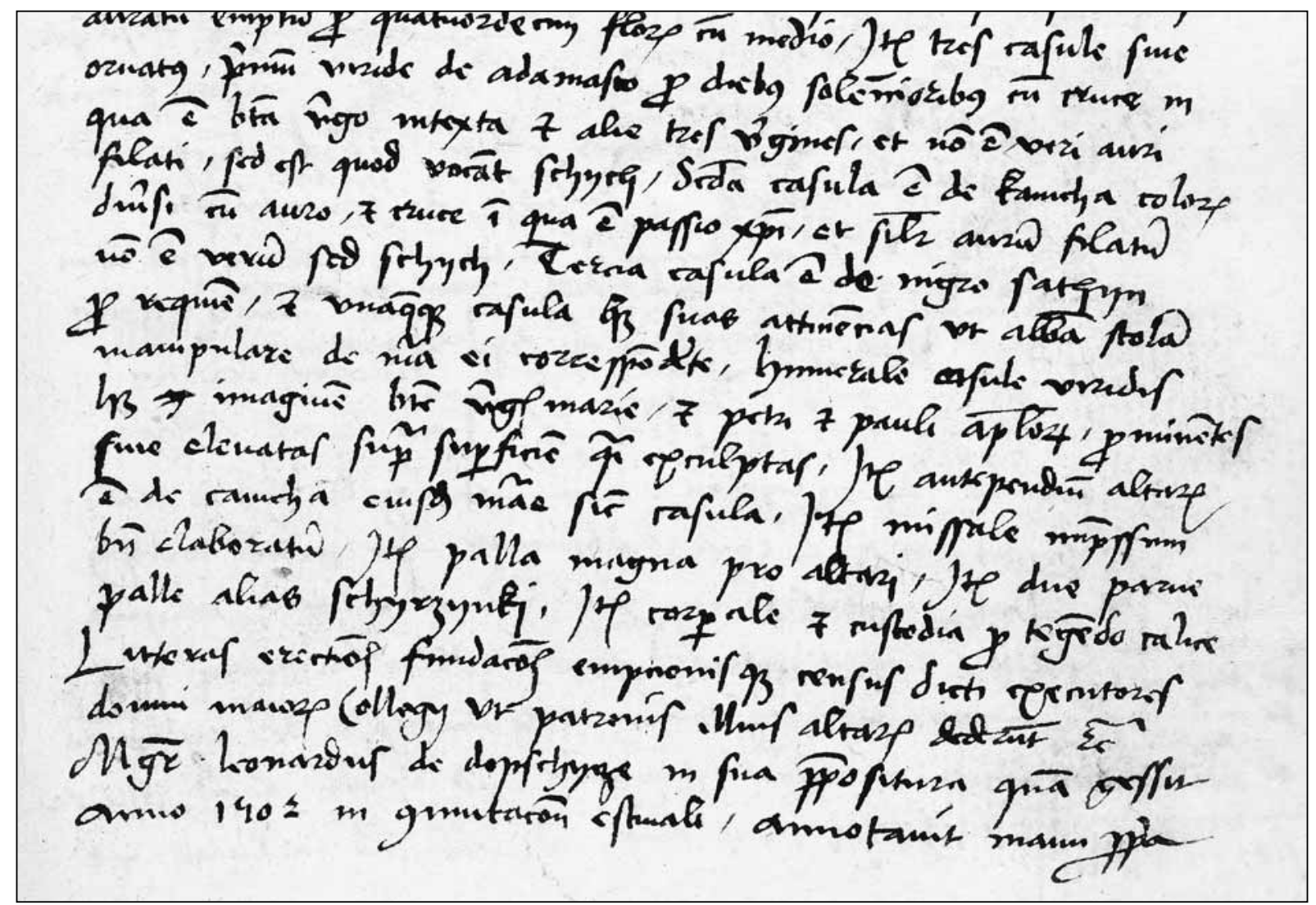

Il. 4: Autograf Leonarda z Dobczyc ( $L C$, s. 43) 


\section{Marcin z Szamotul}

autografy w LC: s. 69: [...] per me magistrum Martinum de Schamothuli, prepositum domus protunc existentem, manu propria etc.

daty: 27 I 1520, prepozyt: Marcin z Szamotuł.

inne przykłady autografów: BJ rkps 249 , k. $61 \mathrm{v}-62 \mathrm{r}^{50}$.

kariera uniwersytecka: student 1499e lub 1500e, bakałarz 1502, magister sztuk 1506, bakałarz dekretów 1514, dwukrotny dziekan Wydziału Sztuk 1516e, 1524h, senior Bursy Ubogich 1514, 1517, prokurator (sindicus, zapewne pełnomocnik) Uniwersytetu 1518, prepozyt Kolegium Większego 1519h, zm. 3 VII 1525 (LC, s. 69; M I 99e/129 lub 1500e/094; NKP 1502/91B, 1506/11M; CUC, s. 152; A. Gąsiorowski, Szamotulscy studenci na krakowskim uniwersytecie w XV i XVI wieku, w: Szamotuły. Karty $z$ dziejów miasta, 1, red. A. Gąsiorowski, Szamotuły 2006, s. 83).

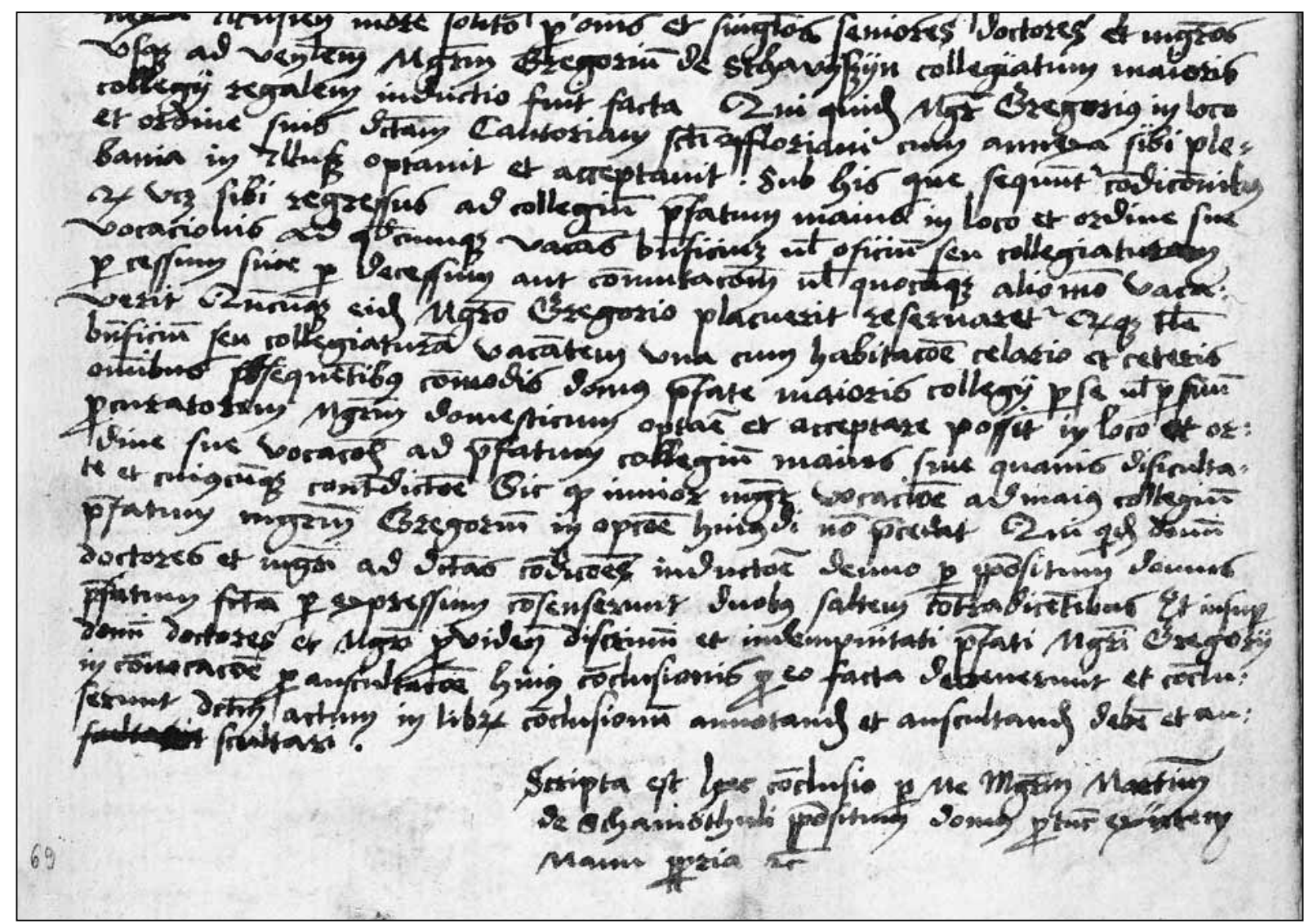

II. 5: Autograf Marcina z Szamotuł (LC, s. 69)

\footnotetext{
${ }^{50}$ Por. wypracowany dukt Marcina z Szamotuł (poświadczony formułą subskrypcyjną manu propria) w BJ rkps 579, s. $178-188$.
} 


\section{Michał Falkener z Wroclawia}

autografy w $L C$ : s. 61-65 [s. 61]: [...] infrascriptis per manum prepositi domus, videlicet magistri Michaelis de Wratislavia [...].

daty: 28 XII 1510, prepozyt: Michał z Wrocławia.

inne przykłady autografów: BJ rkps 249, k. 26v-27r, 40v-41r; BJ rkps 716, k. 80r: Finitum anno 1497 per magistrum Michaelem de Wratislavia commutacione estivali; zob. też reprodukcje not własnościowych w inkunabułach Biblioteki Jagiellońskiej: Wisłocki, Incunabula, s. 561 n. et passim.

kariera uniwersytecka: student 1478e lub 1478h, bakałarz 1481, magister 1488, bakałarz teologii 1510, sentencjariusz 1513, licencjat teologii 1516, doktor teologii 1517, na Wydziale Sztuk od 1488, kolegiat Kolegium Mniejszego 1495-1501, w Kolegium Większym 1501/1502, prepozyt Kolegium Większego $1503 \mathrm{e}, 1510 \mathrm{~h}$, prowizor 1506e, konsyliarz domu 1516e, dwukrotny dziekan Wydziału Sztuk 1499e, 1505h, na Wydziale Teologii od 1512, dziekan Wydziału Teologii 1527h, kanonik kolegiaty św. Floriana 1513, kustosz kolegiaty św. Floriana 1528, prowizor Bursy Nowej (Niemieckiej), zm. 9 XI 1534 ( $L C$, s. 61, 67; BJ rkps 2219, k. 51v, 66r, 70r, 78v, 124r; Diariusz Marcina Biema z Olkusza; M I 78e/082 lub 78h/212; NKP 81/26B, 88/15M; Filozofia w Polsce, s. 265; Gąsiorowski, Bylina i inni, s. 532; Filozofia w Polsce, s. 265 n.; PSB 6, s. 357 n.; Markowski, DzWT, s. 210 n.).

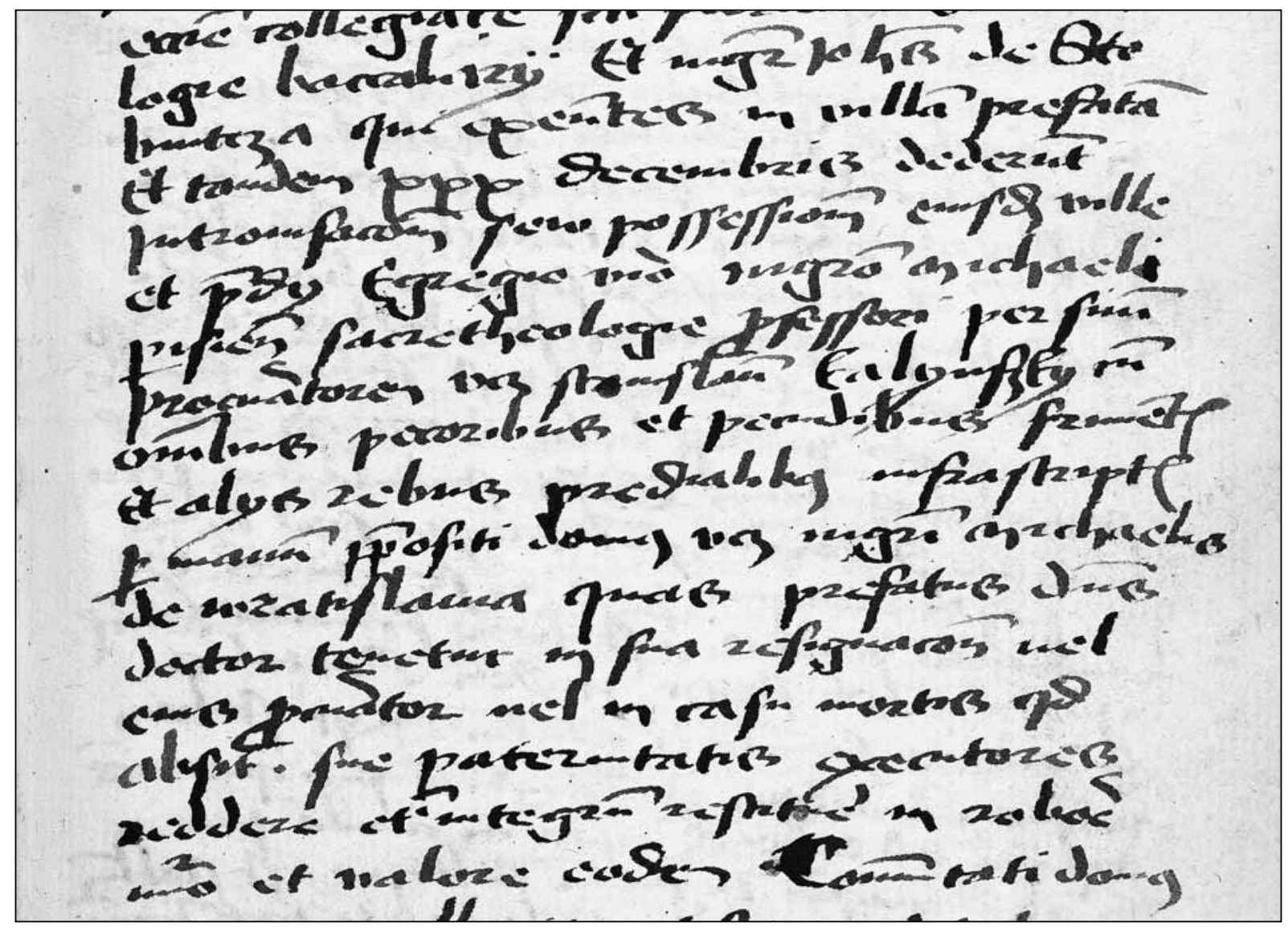

Il. 6: Autograf Michała Falkenera z Wrocławia ( $L C$, s. 61) 


\section{Stanisław Małek z Kleparza}

autografy w LC: s. 58-59: [s. 58] [...] per me magistrum Stanislaum de Cleparz, prepositum domus protunc existentem, manu propria; [s. 59] [...] per me magistrum Stanislaum de Cleparz, prepositum domus protunc existentem, manu propria.

daty: 10 V i 4 VII 1508, prepozyt: Stanisław Małek z Kleparza.

inne przykłady autografów: AUJ rkps 57, s. 87 (z formułą subskrypcyjną manu propria) ${ }^{51}$; BJ rkps 249, k. $28 \mathrm{v}-29 \mathrm{r}$.

kariera uniwersytecka: student 1484h (?), bakałarz 1488, magister sztuk 1491, dziekan Wydziału Sztuk 1500e, do Kolegium Większego wszedł ok. 24 I 1508, prepozyt Kolegium 1508e, zm. 1510 (LC, s. 58 n.; BJ rkps 2219, k. 68r; M I 84h/310 (?); NKP 88/115B, 91/15M; Gąsiorowski, Bylina i inni, s. 529).

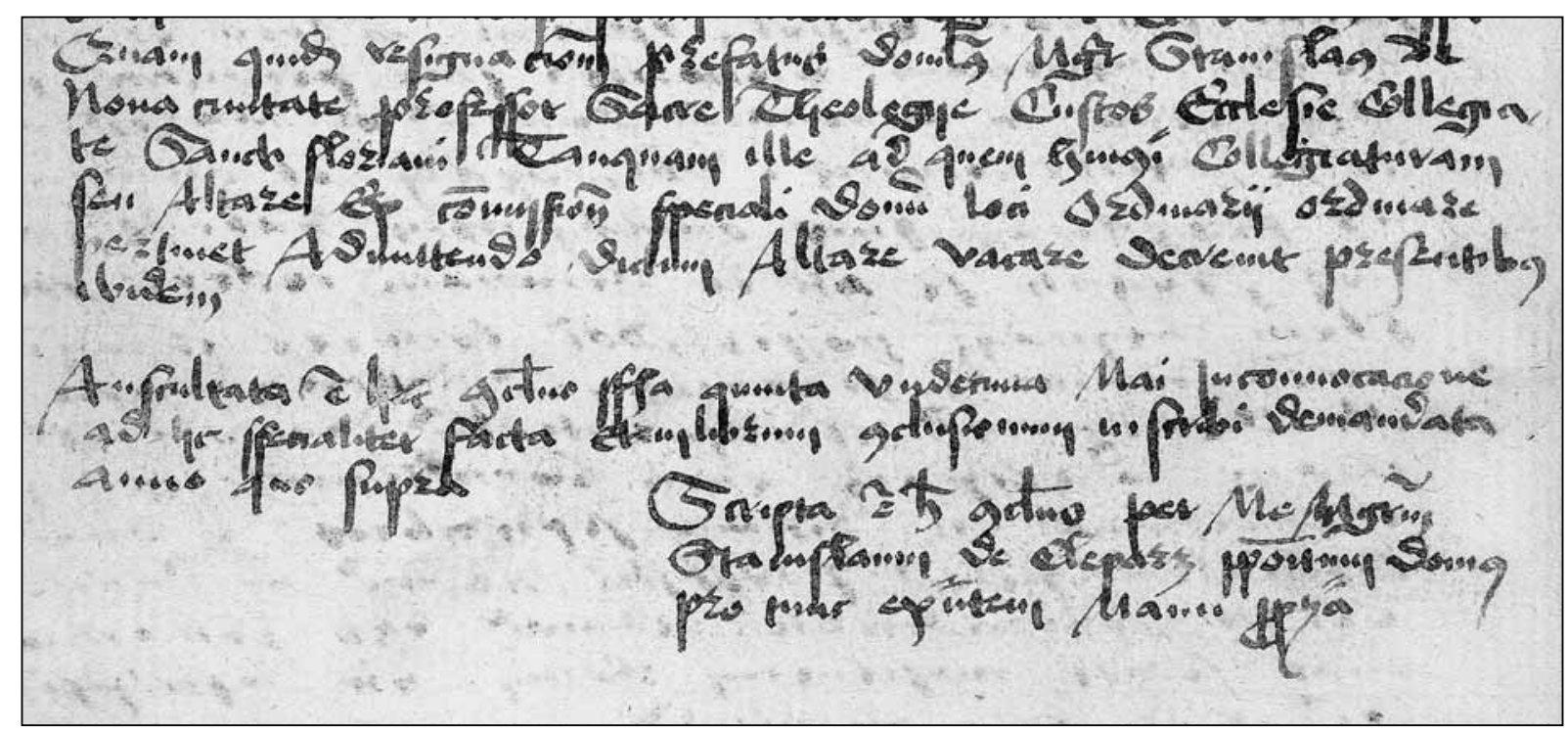

Il. 7: Autograf Stanisława Małka z Kleparza (LC, s. 58)

${ }^{51}$ W BJ rkps 263, k. 54vb-55rb wpisy dziekańskie zostały wniesione, jak się wydaje, ręką Stanisława, lecz odmiennym, wystylizowanym i ozdobnym duktem skrywającym indywidualność pisarza. 


\section{Wojciech z Parlina}

autografy w $L C$ : s. 10: Per me magistrum Albertum de Parlin, protunc prepositum domus.

daty: 13 III i 23 III 1445, prepozyt: Wojciech z Parlina.

inne przykłady autografów: nieznane.

kariera uniwersytecka: student 1430h, bakałarz 1435, magister sztuk 1441, bakałarz teologii przed 1448, prepozyt Kolegium Większego 1444h, dwukrotny dziekan Wydziału Sztuk 1447h, 1451h, zm. najpóźniej w 1453 (LC, s. 10; M I 30h/186, NKP 35/10B, 41/22M; Gąsiorowski, Bylina i inni, s. 530; Markowski, DzWT, s. 164; Kowalczyk, Wypominki, s. 532 [196]).

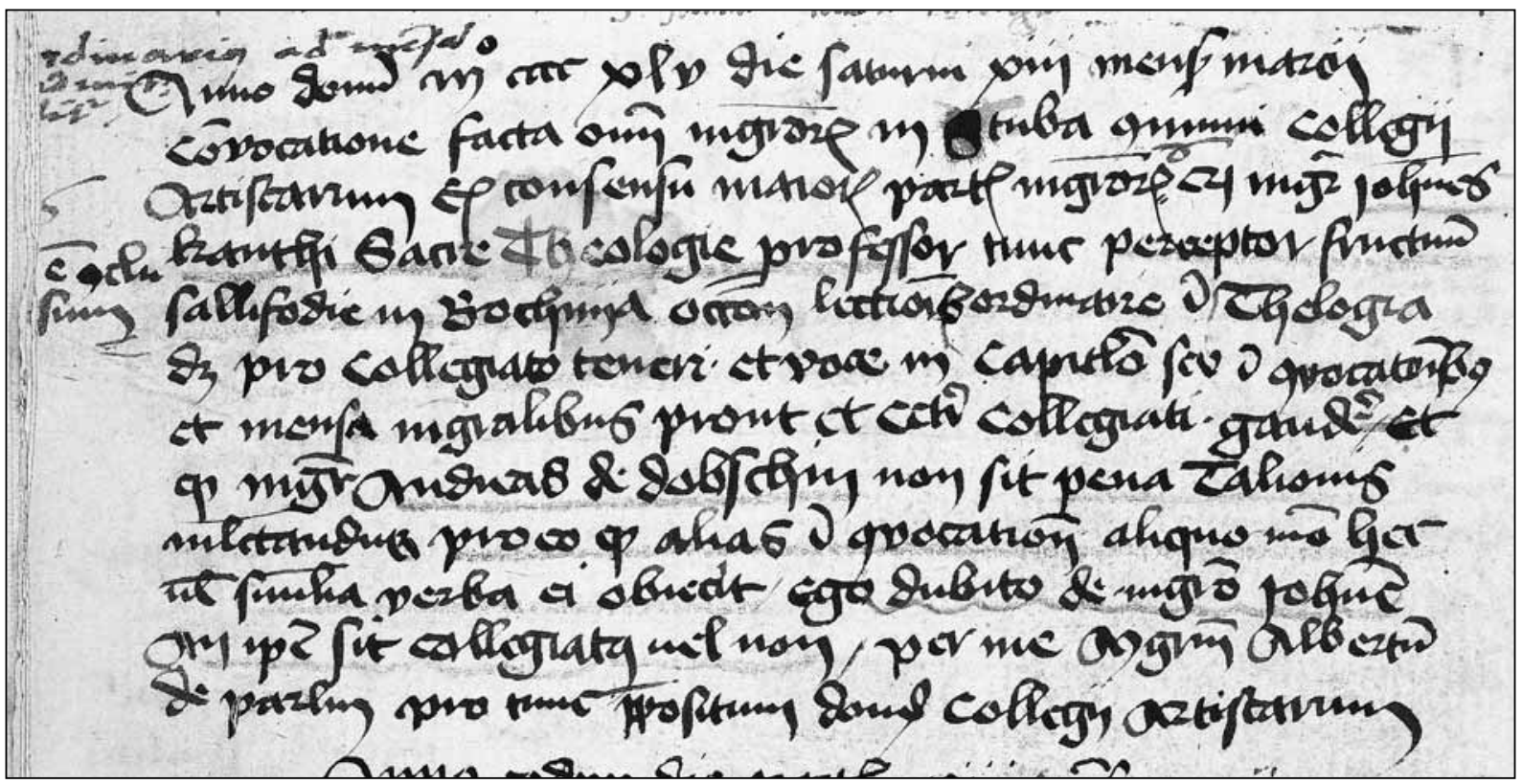

II. 8: Autograf Wojciecha z Parlina ( $L C$, s. 10) 


\section{B. Autografy wysoce prawdopodobne, potwierdzone przez porównanie z innymi kodeksami}

\section{Andrzej Grzymała z Poznania}

autografy w $L C$ : s. 23.

daty: 23 VII 1454, prepozyt: Andrzej Grzymała z Poznania; 1455, zima lub przedwiośnie ${ }^{52}$, prepozyt: Stanisław z Szadka.

inne przykłady autografów: por. AUJ rkps 377a, k. 4v (nagłówek rozliczenia z prokuratorem Uniwersytetu za rektoratu Andrzeja Grzymały); BJ rkps 263, k. 22vb, 25ra; BJ rkps 832, liczne marginalia m.in. na k. 14v, 15r, 23r-25r, 61r, 62v, 90r, 116v (przy prawej kolumnie), 153v-154r i in.

kariera uniwersytecka: student 1442e, bakałarz 1443, magister sztuk 1447, doktor medycyny w Rzymie (?) przed 3 XI 1461, doktor dekretów w Ferrarze 23 XII 1461, bakałarz teologii 1465, w Kolegium Mniejszym 1449, prepozyt Kolegium Większego 1454e, być może także 1464h, dwukrotny prokurator uniwersytetu w Kurii Rzymskiej 16 VIII 1456-1458, 7 VII 1460-1461/1462, dwukrotny dziekan Wydziału Sztuk 1453h, 1458e, dziekan Wydziału Medycyny 1464h, dwukrotny rektor 1465h, 1466e, zm. 26 X 1466 (BJ rkps 2219, k. 3r-v, 8r; M I 42e/004; NKP 43/27B, 47/6M; PSB 9, s. 114-116; Bukowski, Rachunki 2, s. 676, przyp. 12; tenże, Rachunki 1, przyp. 1; S.A. Sroka, Polscy absolwenci uniwersytetu w Ferrarze w drugiej połowie XV wieku, w: Ecclesia - regnum - fontes. Studia z dziejów średniowiecza, red. S. Gawlas et alii, Warszawa 2014, s. 588-590 - tam dalsza literatura).

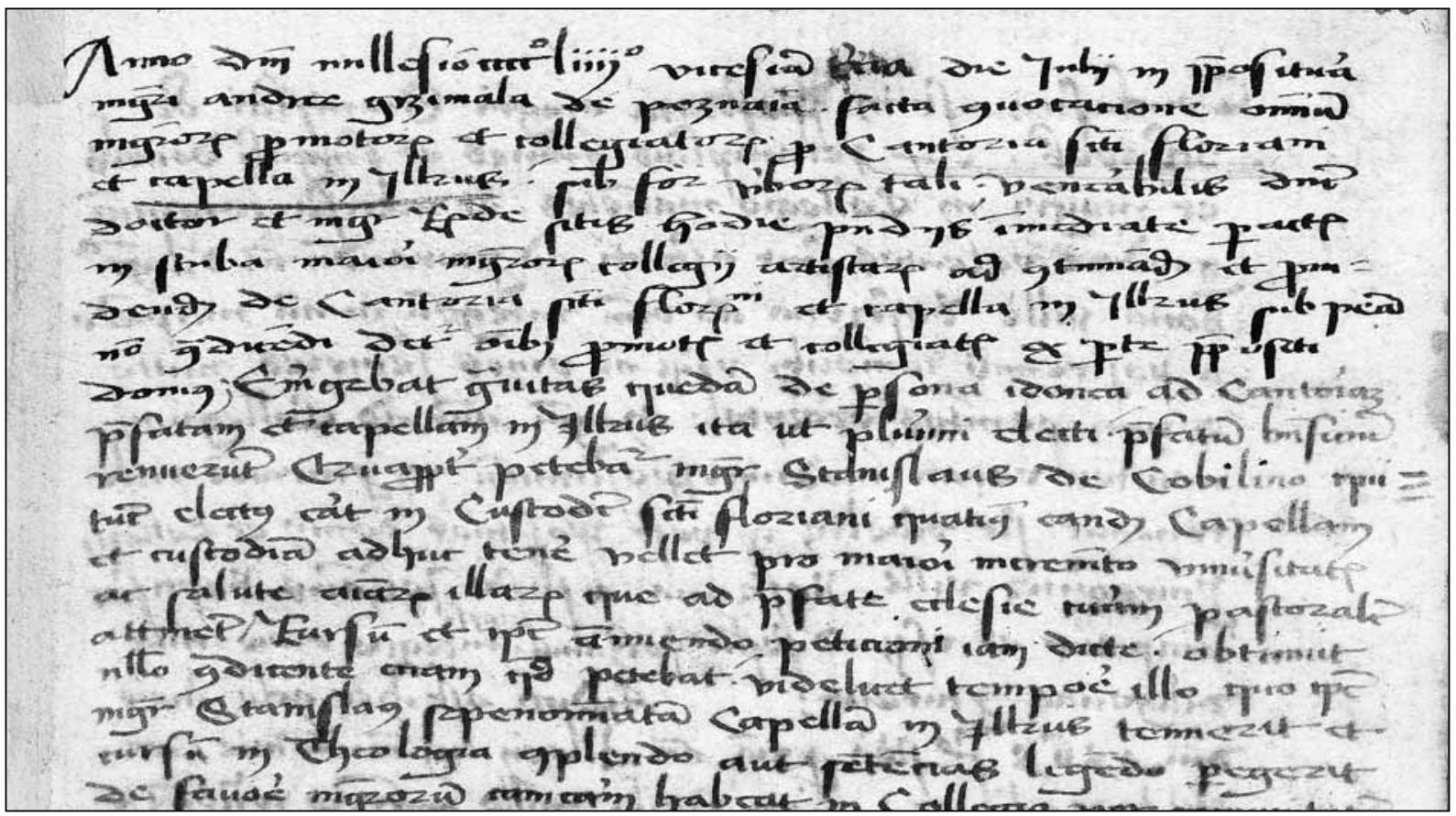

Il. 9: Autograf Andrzeja Grzymały z Poznania ( $L C$, s. 23)

\footnotetext{
${ }^{52}$ Zapiska o charakterze inwentarzowym, pozbawiona daty dziennej, wzmiankuje jednak pola z zasiewem ozimym (seminatura hiemalis in pluribus campis) oraz obecność w stadzie licznych kotnych owiec (octuaginta quatuor oves, inter quas multe fetantes). Ponadto znani są prepozyci urzędujący w następnych semestrach $1455 \mathrm{r}$.
} 


\section{Andrzej ze Starogardu (z Sumina)}

autografy w $L C$ : s. 24-25.

daty: 19 III 1466, prepozyt: Andrzej ze Starogardu (de Stargardia alias de Sommen).

inne przykłady autografów: BJ rkps 263, k. 26vb-27ra (odmienny, ozdobny dukt); BJ rkps 301, s. 647660: [s. 660] [...] per me magistrum Andream de Stargardia [...].

kariera uniwersytecka: student 1443h, bakałarz 1446, magister sztuk wyzwolonych 1452, bakałarz biblijny 1466, bakałarz format 1474, senior Bursy Jerozolimskiej 1456, senior Bursy Ubogich 1461, do Kolegium Większego wszedł prawdopodobnie w 1465, prepozyt Kolegium Większego 1465h, prowizor Kolegium 1466e, skarbnik Kolegium 1466h, kantor kapituły św. Floriana i proboszcz w Olkuszu 26 IV 1467, kanonik kolegiaty św. Floriana 1473, dziekan Wydziału Sztuk 1460e, 1472h, konsyliarz rektora 1473, zm. po 10 IX 1477 ( $L C$, s. 25-26, 122; BJ rkps 2219, k. 5v ${ }^{53}, 11 \mathrm{r}, 12$ r; M I 43h/118; NKP 46/12B, 52/4M; A. Karbowiak, Ustawy bursy krakowskiej „Jeruzalem” (1453-1841), ADLOP, 6, 1890, s. 95, 97; Bukowski, Rachunki 2, s. 687, przyp. 45 — tam dalsza literatura).

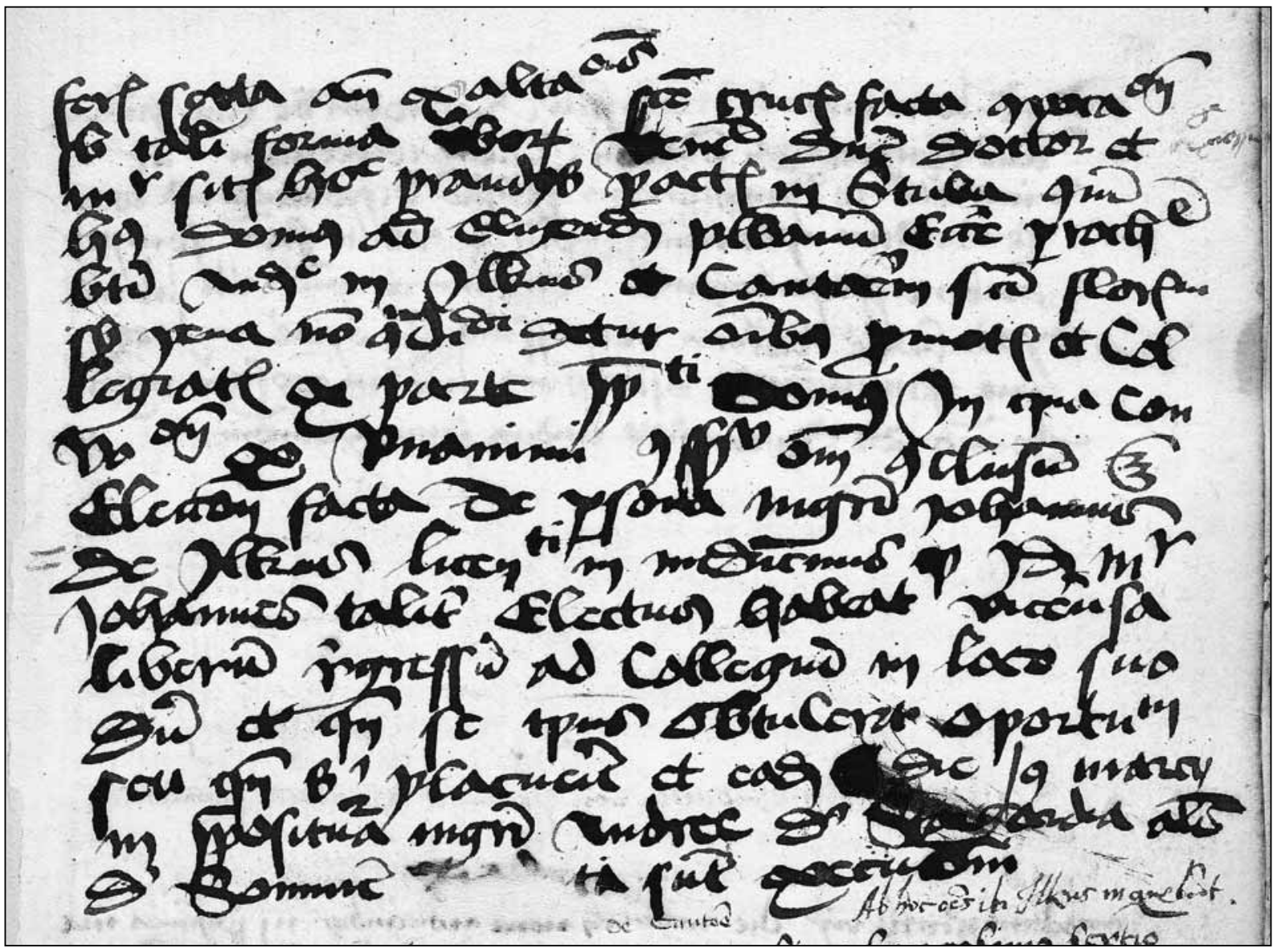

Il. 10: Autograf Andrzeja ze Starogardu ( $L C$, s. 25)

${ }^{53}$ Zapiska o uiszczeniu opłaty za wstęp do Kolegium, tzw. introitaliów, wpisana ręką osoby prowadzącej rachunki w roku 1465. 


\section{Bartlomiej z Radomia}

autografy w $L C$ : s. 2-3, 5-6.

daty: 29 IV - 12 V 1432, prepozyt: Jan z Radochoniec ${ }^{54}$; 16 I - 10 III 1440, prepozyt: Bartłomiej z Radomia.

inne przykłady autografów: por. BJ rkps 258 , s. 190 - wpisy rozpoczynające się od słów: In rectoratu magistri Bartholomei de Radom ${ }^{55}$ (reprodukcja s. $190 \mathrm{z}$ autografem Bartłomieja w: Metryka, t. 1, s. 646); BJ rkps 263, k. 10vb (nota u dołu kolumny o przyjęciu do wydziału), 15rb (nagłówek), 15va (nota u góry kolumny o przyjęciu do wydziału i następujący po niej nagłówek).

kariera uniwersytecka: student 1419, bakałarz 1421, mistrz sztuk 1427, bakałarz biblijny ok. 1436, doktor teologii 1444, konsyliarz prepozyta Kolegium Większego 1432e, prepozyt Kolegium Większego 1439h, kanonik kolegiaty św. Floriana 1443, prowizor dóbr tejże 1446, dwukrotny dziekan Wydziału Sztuk 1436h, 1437e, członek komisji do rewizji statutów Wydziału Sztuk 1441, dwukrotny rektor 1444h, 1445e, zm. 1449/1450 (LC, s. 2, 5-6; M I 19e/007 oraz P205; NKP 21/25B, 27/3M; PSB 1, s. 316 n.; PoczetR, s. 71).

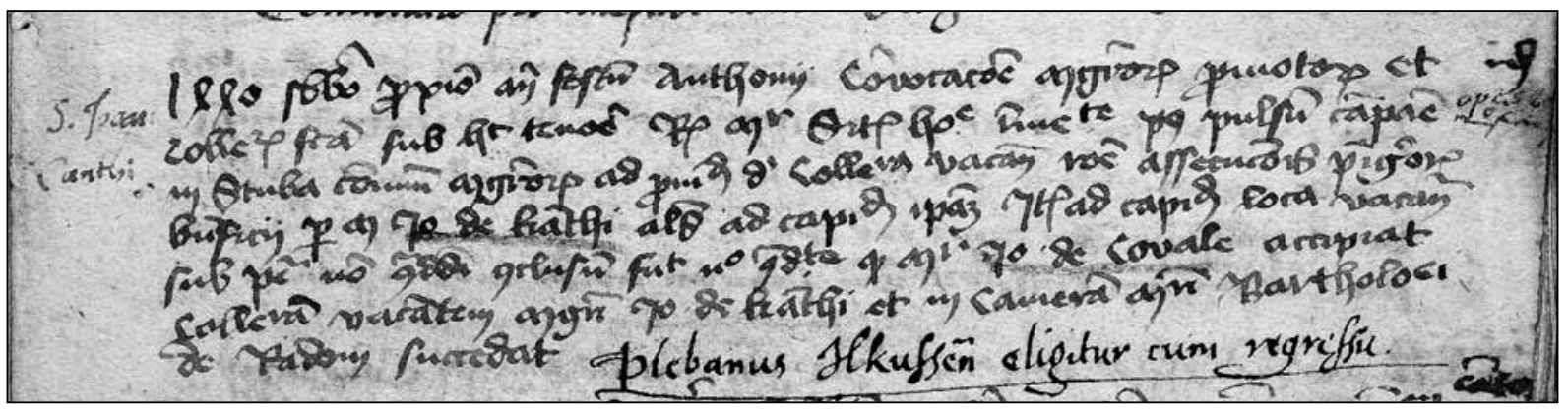

Il. 11: Autograf Bartłomieja z Radomia ( $L C$, s. 5)

\footnotetext{
${ }^{54}$ Bartłomiej był wówczas konsyliarzem prepozyta i być może dlatego w zastępstwie Jana wnosił wpisy do $L C$.

${ }_{55}$ W wydaniu Metryki są to wpisy nr Z10-Z23 (Metryka, t. 1, s. 649 n.).
} 


\section{Bernard z Biskupiego (z Krakowa, zw. Kapustka)}

autografy w $L C$ : s. 37.

daty: 15 V 1494, prepozyt: Bernard z Biskupiego.

inne przykłady autografów: potwierdzone pismo kursywne Bernarda w AUJ rkps 177, s. 19: Ego $d<$ octor $>$ Bernhardus custos ecclesie sancti Floriani scripsi et subscripsi; s. 20 (tylko subskrypcja): Ego doctor Bernardus [...] subscripsi; BJ rkps 248, k. 11v-12 $\mathrm{r}^{56}$ (w obydwu rękopisach pismo identyczne jak w $L C$ ); BJ rkps 263, k. 49rb; por. też niektóre glosy w BJ rkps $1518^{57}$, oraz wpis w BJ rkps 2219, k. 71v (od słów: Item ab uno decimali lignorum do słów: propter faciliorem intromissionem, unus grossus); BJ Cim. 5515, k. $\mathrm{u}^{6} \mathrm{v}, \mathrm{y}^{12} \mathrm{v}, \mathrm{z}^{11} \mathrm{v}, \mathrm{ca}^{2} \mathrm{v}, \mathrm{cc}^{14} \mathrm{r}$ et passim.

kariera uniwersytecka: student 1473e, bakałarz 1477, magister sztuk 1484, bakałarz medycyny 1492 , bakałarz biblijny 1497, licencjat 1503, doktor teologii 30 I 1504, kolegiat Kolegium Mniejszego co najmniej w 1487, senior Bursy Ubogich 1492, do Kolegium Większego wszedł zapewne w 1492e, prepozyt Kolegium Większego 1492h, 1494e, skarbnik Kolegium 1516, kanonik kapituły św. Floriana 1504, kantor kapituły św. Floriana i proboszcz w Olkuszu od marca 1506 (zrezygnował przed końcem tego roku), kustosz kapituły św. Floriana 1516, prokurator dóbr 1520 i dziekan 1522 tamże, dwukrotny

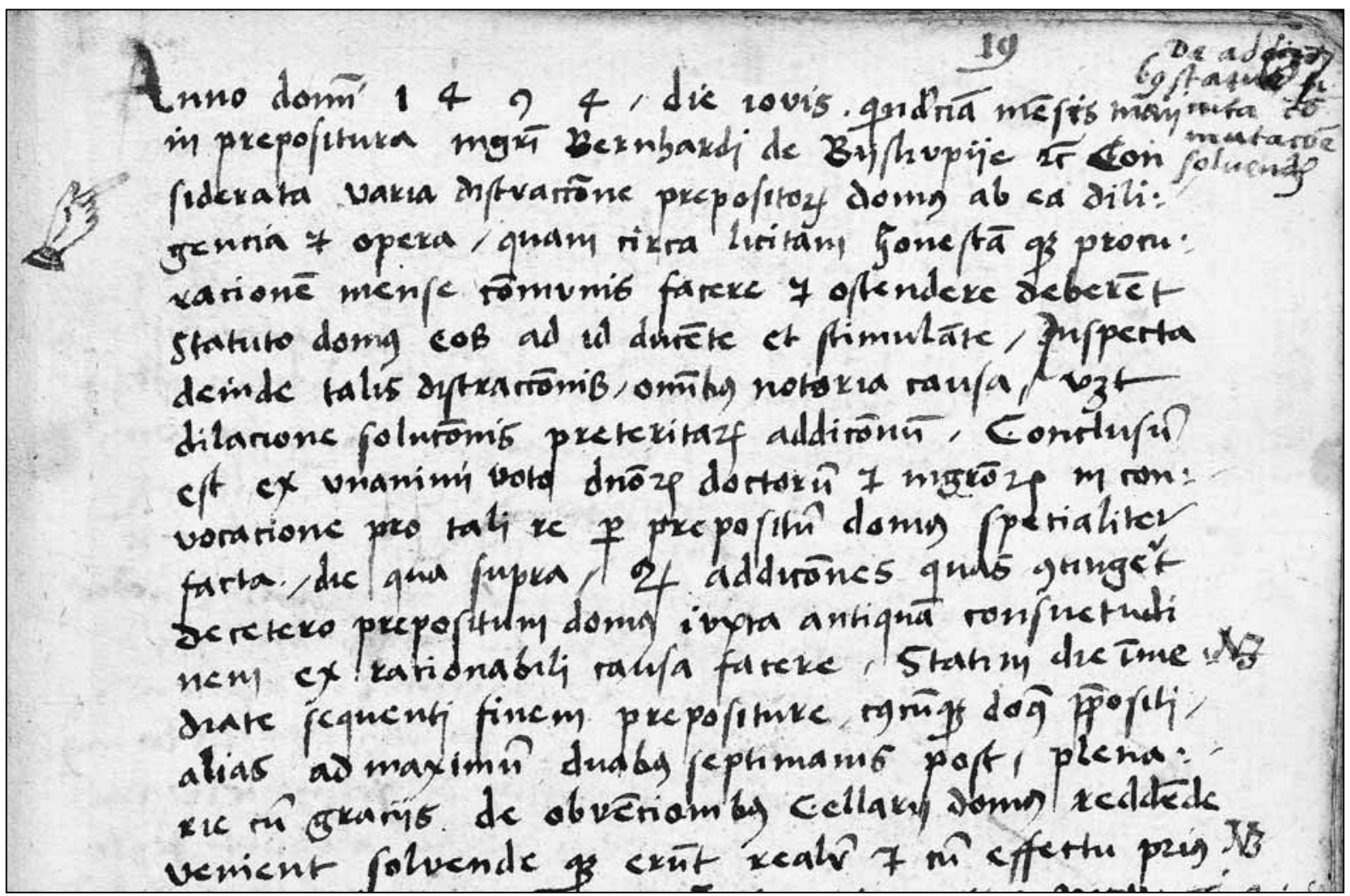

Il. 12: Autograf Bernarda z Biskupiego ( $L C$, s. 37)

\footnotetext{
${ }^{56}$ Podczas kolejnego dziekanatu Bernarda w semestrze zimowym 1497 r. wpisy do ksiąg wnosił, jak się wydaje, Stanisław Bylica z Olkusza: BJ rkps 263, k. 52vb-53rb i BJ rkps 249, k. 22v-23r. Pismo Stanisława zob. niżej, nr 17.

${ }^{57}$ BJ rkps 1518 to egzemplarz anonimowego Komentarza do I księgi Sentencji Piotra Lombarda Utrum Deus gloriosus, używany przez wiele pokoleń krakowskich teologów. Por. Z. Włodek, Krakowski komentarz z XV wieku do „, Sentencji” Piotra Lombarda, cz. 1: Wstęp historyczny i edycja tekstu księgi I i II, „Studia Mediewistyczne”, 7, 1966, s. 142-144. Z Bernardem z Biskupiego łączę glosy m.in. na k. 105r: Inde habetur, quod nulla inter Patrem et Filium potest esse realis prioritas [...], 144v: B<ona $>V<$ entura $>$. Processione temporali procedit a se Spiritus Sanctus [...], 378r: Hoc solum Deus non potest, quod non wlt [...], 385r: Utrum Deus potuerit facere universum melius [...], 398v: B<ona $>V<$ entura $>$ (?). Malum locum habet [...], 400r: A minori. $B<$ ona $>V<$ entura $>$. Videtur falsum dicere [...].
} 
dziekan Wydziału Sztuk 1492e, 1497h, dziekan Wydziału Teologii 1507h, konsyliarz rektora 1500, 1527, wicekonserwator Uniwersytetu 1522, 1527, członek komisji do opracowania statutów Wydziału Lekarskiego 1525, pięciokrotny rektor Uniwersytetu 1506h, 1507e, 1527h-1528h, zm. 24 IV 1531 ( $L C$, s. 37, 48-49; BJ rkps 2219, k. 45r, 71r, 121r; wybór na prokuratora i data śmierci wg Diariusza Marcina Biema z Olkusza; M I 73e/052; NKP 77/74B, 84/6M; LD, s. 3; CUC, s. 457; Statuta Bursae Longini, s. LXXXVIII n.; PSB 1, s. 458 n.; Markowski, DzWT, s. 204 n.; PoczetR, s. 123).

\section{Bernard Mikosz z Nysy (Krotinphul)}

autografy w $L C$ : s. 26-27.

daty: 9 XI 1467, prepozyt: Bernard z Nysy; przedwiośnie 1468?, zapiska o charakterze inwentarzowym niedatowana, bez wzmianki o prepozycie.

inne przykłady autografów: BJ rkps 263, k. 32va-33rb 58 ; BJ rkps 515, wyklejka górnej okładki, k. Ir (zapiska własnościowa), 3v-4r (marginalia), 163v, 190r; BJ rkps 689, k. 122v; BJ rkps 1431, k. Iv ${ }^{59}$; niektóre glosy w BJ rkps $1518^{60}$.

kariera uniwersytecka: student 1455 h, bakałarz 1458, magister sztuk wyzwolonych 1462, bakałarz teologii ok. 1473, licencjat 1482, doktor teologii przed listopadem 1484, profesor na Wydziale Teologii 1485, prepozyt Kolegium Większego 1467h, prowizor Kolegium 1468e, 1475e, 1487e, kanonik kolegiaty św. Floriana 1477, kustosz tamże 1489, dziekan Wydziału Sztuk 1470h, konsyliarz rektora 1480, 1489, rektor Uniwersytetu 1489h, zm. 2 II 1490, część księgozbioru legował Wydziałowi Teologii (LC, s. 26; BJ rkps 2219, k. 14r, 15v, 16v, 31r, 38r; M I 55h/173; NKP 58/19B, 62/2M; Statuta Bursae Longini, s. LXX; PSB 1, s. 460; Bukowski, Rachunki 2, s. 699, przyp. 68 - tam wiadomości o karierze pozauniwersyteckiej i dalsza literatura).

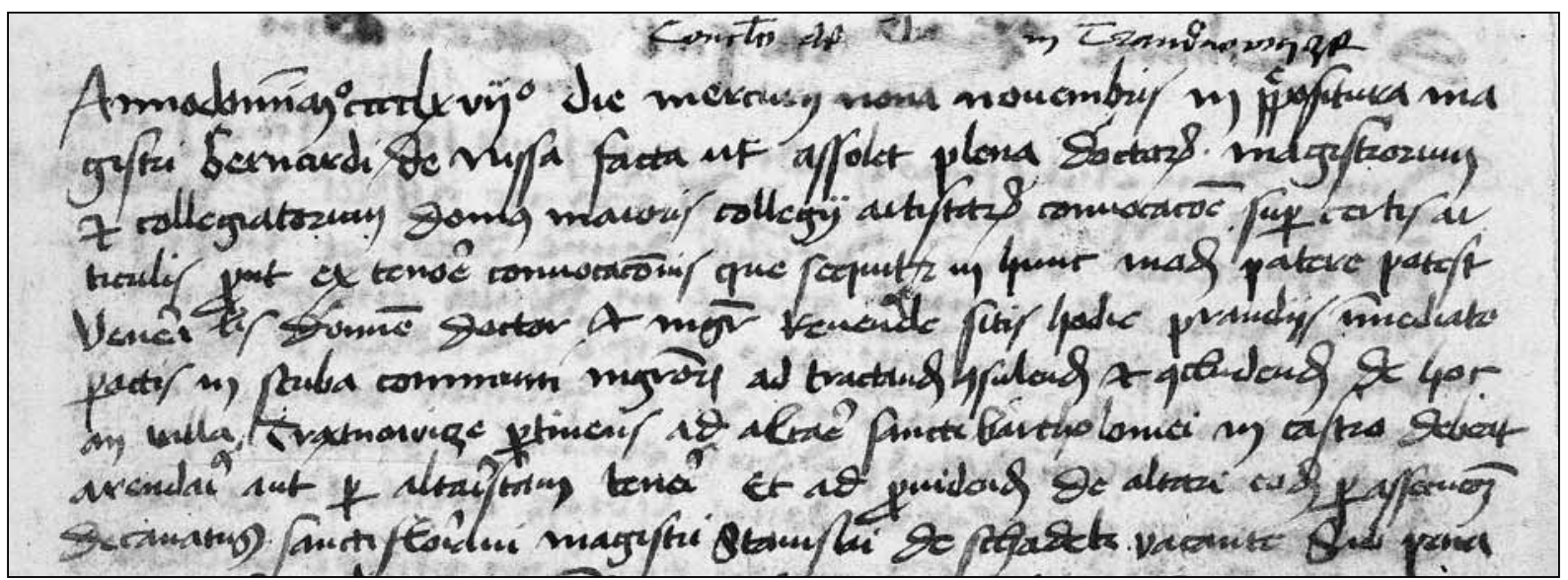

Il. 13a: Autograf Bernarda Mikosza z Nysy, typ pisma 1 ( $L C$, s. 26)

\footnotetext{
58 Autograf zidentyfikowany przez Wydawców, Najstarsza księga promocji, s. XVI.

59 Pismo Bernarda mylnie przypisane Mikołajowi Tauchanowi z Nysy w BJ rkps 1431, k. Iv (Catalogus BJ, t. 10, s. 5). Katalog powołuje się tam na fragment wiersza w BJ rkps 689 , k. 122v zakończonego subskrypcją per Nicolaum Tauchan de Nissa. Porównanie ręki Mikołaja Tauchana w BJ rkps 1865 i ręki z BJ rkps 689, k. 122v prowadzi do wniosku, że subskrypcja odnosi się do autorstwa wiersza, nie zaś do osoby kopisty, którym był Bernard Mikosz z Nysy. Pismo Mikołaja Tauchana w BJ rkps 1865, k. 1r-37r, 69v-143r (kolofon k. 143r: Et scripte sunt thabule hec anno Domini millesimo quadringentesimo sexagesimo per Nicolaum de Nissa arcium baccalarium. [Późniejszy dopisek pismem bardziej uroczystym:] Qui anno Domini $1474^{\circ}$ doctor iuris canonici creatus est Cracovie. Za konsultację paleograficzną serdecznie dziękuję dr Lucynie Nowak i dr. Ryszardowi Tatarzyńskiemu. Podpis Mikołaja Tauchana reprodukuje W. Wisłocki, Incunabula, s. 503.

${ }^{60}$ Np. k. 20v: Ista subdivisio [...], Benivolum autem [...], 56r: Notandum: Ista Trinitas [...], Pe $<$ trus $>$ de Ta $<$ rantasia $>$, Quidam dicunt, quod mens [...], 348v: Deus potest scire aliquid [...], 358v: Referatur. Et ista causa [...], 387r: To<mas $>$ (?) hic in Scripto. Opus determinatum non progreditur nisi a determinato agente [...].
} 


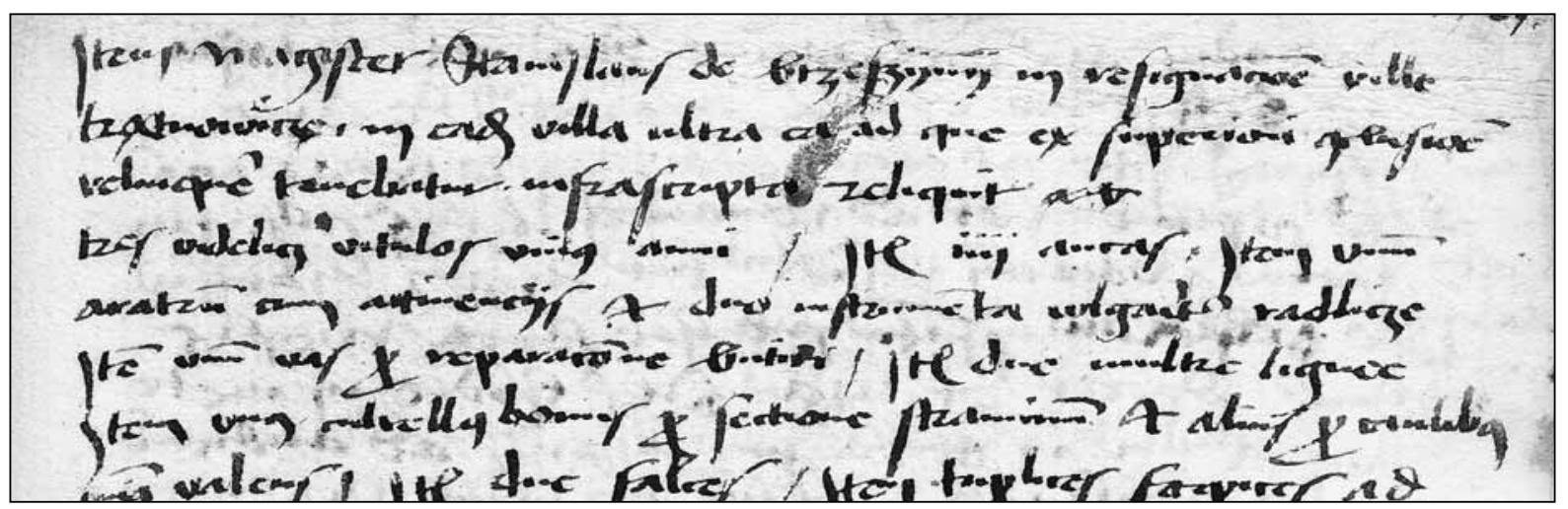

Il. 13b: Autograf Bernarda Mikosza z Nysy, typ pisma 2 ( $L C$, s. 27)

\section{Jakub z Gostynina}

autografy w $L C$ : s. 40-41.

daty: 1497, prepozyt: Jan z Leśnicy.

inne przykłady autografów: AUJ rkps 177, s. 7: Ego magister Jacobus de Gosthinyn [...] recognosco me recepisse [...]; BJ rkps 249, k. 8v-9r, 20v-21r; BJ rkps 258, s. 487-49761; BJ rkps 263, k. 47r- $\mathrm{v}^{62}$, 52va-vb; BJ rkps 491, s. 41a-70a, 81b-214a et passim.

kariera uniwersytecka: student 1472h, bakałarz 1473, magister sztuk 1477, bakałarz teologii 1494, doktor teologii 1500, kolegiat Kolegium Mniejszego przed 1487, prepozyt Kolegium Większego 1490e, 1498e, prowizor tamże 1494e, kanonik kolegiaty św. Floriana 1499, dwukrotny dziekan Wydziału Sztuk 1490h, 1496h, senior Bursy Ubogich 1505, dwukrotny rektor Uniwersytetu 1503h, 1504e, wicekanclerz Uniwersytetu 1503-1506, zm. 16 II 1506, legował Uniwersytetowi swój księgozbiór (AUJ rkps 57, s. 75; BJ rkps 2219, k. 42r, 47v-48r; M I 72h/075 lub 091; NKP 73/65B, 77/4M; PSB 10, s. 352 (z nieścisłościami); Bukowski, Rachunki 2, s. 712, przyp. 97 — tam dalsza literatura).

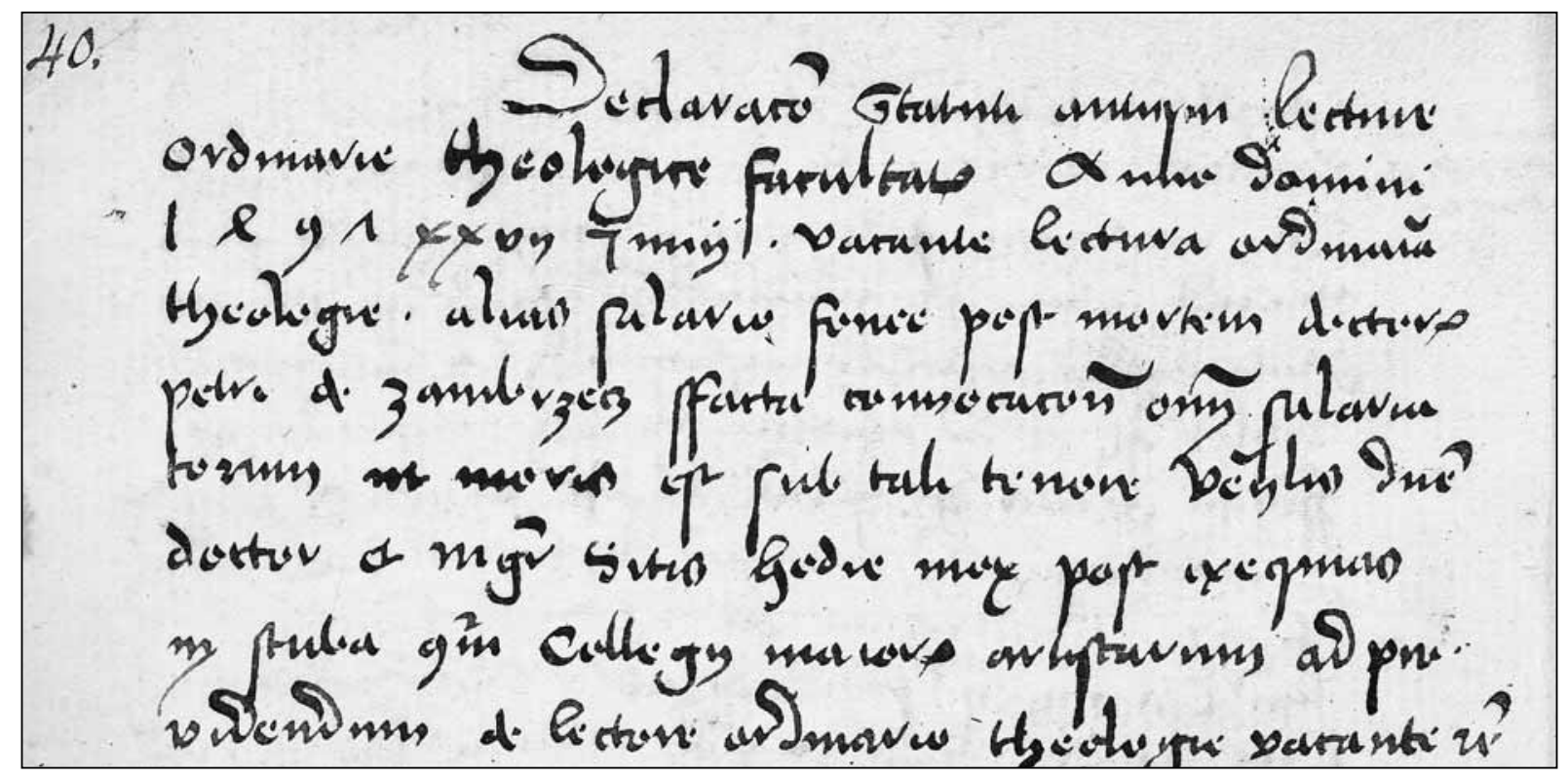

Il. 14: Autograf Jakuba z Gostynina ( $L C$, s. 40)

\footnotetext{
${ }^{61}$ Autografy zidentyfikowane przez Wydawców, Metryka, t. 1, s. 600, 604.

${ }^{62}$ Autograf zidentyfikowany przez Wydawców, Najstarsza księga promocji, s. XVI.
} 


\section{Jan z Dąbrówki}

autografy w $L C$ : s. 14-21.

daty: 18 X - 31 XII 1449, prepozyt: Jan z Dąbrówki.

inne przykłady autografów: BJ rkps 263, k. 13rb-v, 14ra-va; BJ rkps 258, s. 173b-175, 182b, 245248, 248-250, 263a-266, 266-26763; BJ rkps 1406, k. 159r: [...] finitum [...] per Johannem de Dambrowka decretorum doctorem anno 1449. Liczne zdjęcia autografów Jana z Dąbrówki opublikowano w: M. Zwiercan, Komentarz Jana z Dąbrówki, il. 1-4, il. 10 z reprodukcją s. 17 rękopisu LC. Marginalia Jana z Dąbrówki z rkps BJ 1352 reprodukowano w: M. Kowalczyk, Colligite fragmenta, il. 20.

kariera uniwersytecka: student 1420h, bakałarz 1421, magister sztuk wyzwolonych 1427, bakałarz teologii 1434/1435, doktor dekretów 1440, licencjat 1446 i doktor teologii co najmniej 1449, profesor na katedrze retoryki Tomasza Nowka 1427, profesor na Wydziale Prawa, profesor na Wydziale Teologii od 1450, w Kolegium Większym co najmniej w 1432, prepozyt Kolegium Większego 1449h, 1460h, kanonik kolegiaty św. Floriana 1446, tamże kustosz 1462-1467, prowizor Bursy Ubogich 1468, dwukrotny dziekan Wydziału Sztuk 1433h, 1434e, dziekan Wydziału Teologii 1464h, 1465h, członek komisji do reformy statutów uniwersyteckich 1464, dziewięciokrotny rektor 1446h, 1451h, 1453h, 1458e, 1458h, 1467e, 1467h, 1471e, 1471h, wicekanclerz Uniwersytetu 1458-1465, zm. 11 I 1472, legował Uniwersytetowi swoją pokaźną bibliotekę ( $L C$, s. 14; BJ rkps 2219, k. 3r, 4r; M I 20h/223 i P201; NKP 21/30B, 27/2M; CUC, s. 464; PSB 5, s. 26-28; Bukowski, Rachunki 2, s. 682, przyp. 31 - tam wiadomości o karierze pozauniwersyteckiej i dalsza literatura).

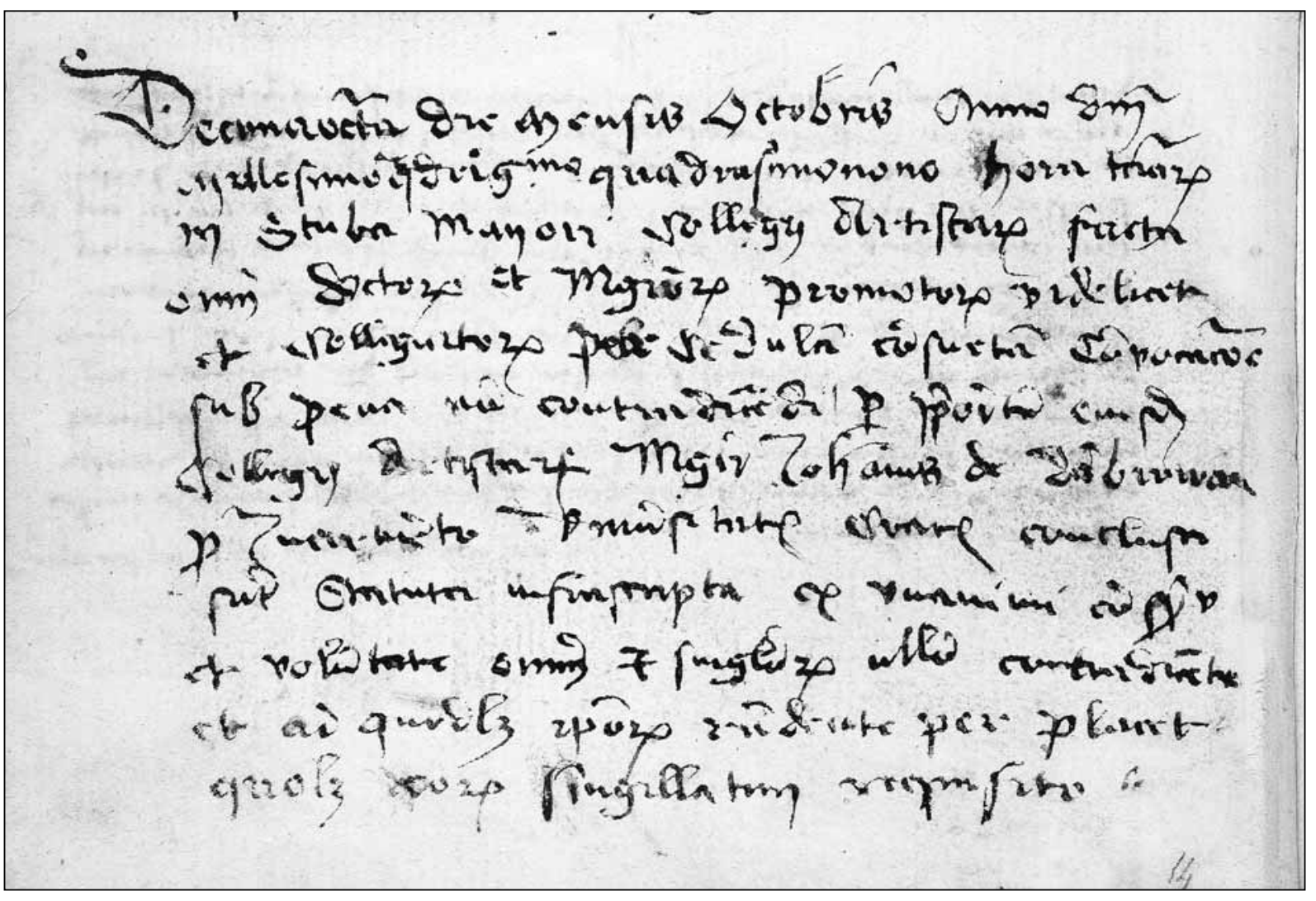

Il. 15: Autograf Jana z Dąbrówki ( $L C$, s. 14)

${ }^{63}$ Autografy zidentyfikowane przez Wydawców, Metryka, t. 1, s. 238, 246, 320, 324, 347, 352. 


\section{Jan z Leśnicy}

autografy w $L C$ : s. 38-39.

daty: 20 IX 1497, prepozyt: Jan z Leśnicy.

inne przykłady autografów: AUJ rkps 177, s. 20: Ita est. Jo<hannes $>$ de Lesthnÿcza ${ }^{64}$; AUJ Dypl. perg. 350 (z formułą transivit per manus); BJ rkps 249, k. 19v-20r, 36v-37r; BJ rkps 263, k. 52va, 59va-60ra. Janowi z Leśnicy można przypisać niektóre glosy w komentarzach do I i II księgi Sentencji w rękopisach BJ 1518 i $1519^{65}$.

kariera uniwersytecka: student 1475e bakałarz 1484, magister sztuk 1488, bakałarz teologii (biblijny?) 1503, bakałarz sentencjariusz 1504, bakałarz format 1505, doktor teologii 1507, kolegiat Kolegium Mniejszego 1490, do Kolegium Większego wszedł około 28 II 1497, prepozyt 1497e, dwukrotny dziekan wydziału Sztuk 1496e, 1503h, senior 1494 i prowizor Bursy Ubogich 1510, profesor na Wydziale Teologii 1507-1513, dziekan Wydziału Teologii 1510h, kanonik kapituły św. Floriana 1509, roczny urlop od zajęć uniwersyteckich od stycznia 1512, członek komisji rektorskiej 1513, uzyskał zwolnienie z katedry teologii 1513, kanonik kapituły katedralnej w Gnieźnie 1513, wykładowca teologii tamże, w 1518 Uniwersytet odmówił mu urlopu z powodu licznych nieobecności, zm. 30 XI 1526, zasłużony licznymi pracami na rzecz Uniwersytetu i środowiska, legował Uniwersytetowi sto grzywien ( $L C$, s. 51, 60, 65-67; AUJ rkps 69, s. 50, 51; BJ rkps 2219, k. 57v; data śmierci wg Diariusza Marcina Biema z Olkusza; M I 75e/075; NKP 84/82B, 88/3M; AR I, s. 1023; CUC, s. 472; LD, s. 440-441; Statuta Bursae Longini, s. LXXXVIII; Wisłocki, Incunabula, s. 286 n.; Markowski, DzWT, s. 206 n.).

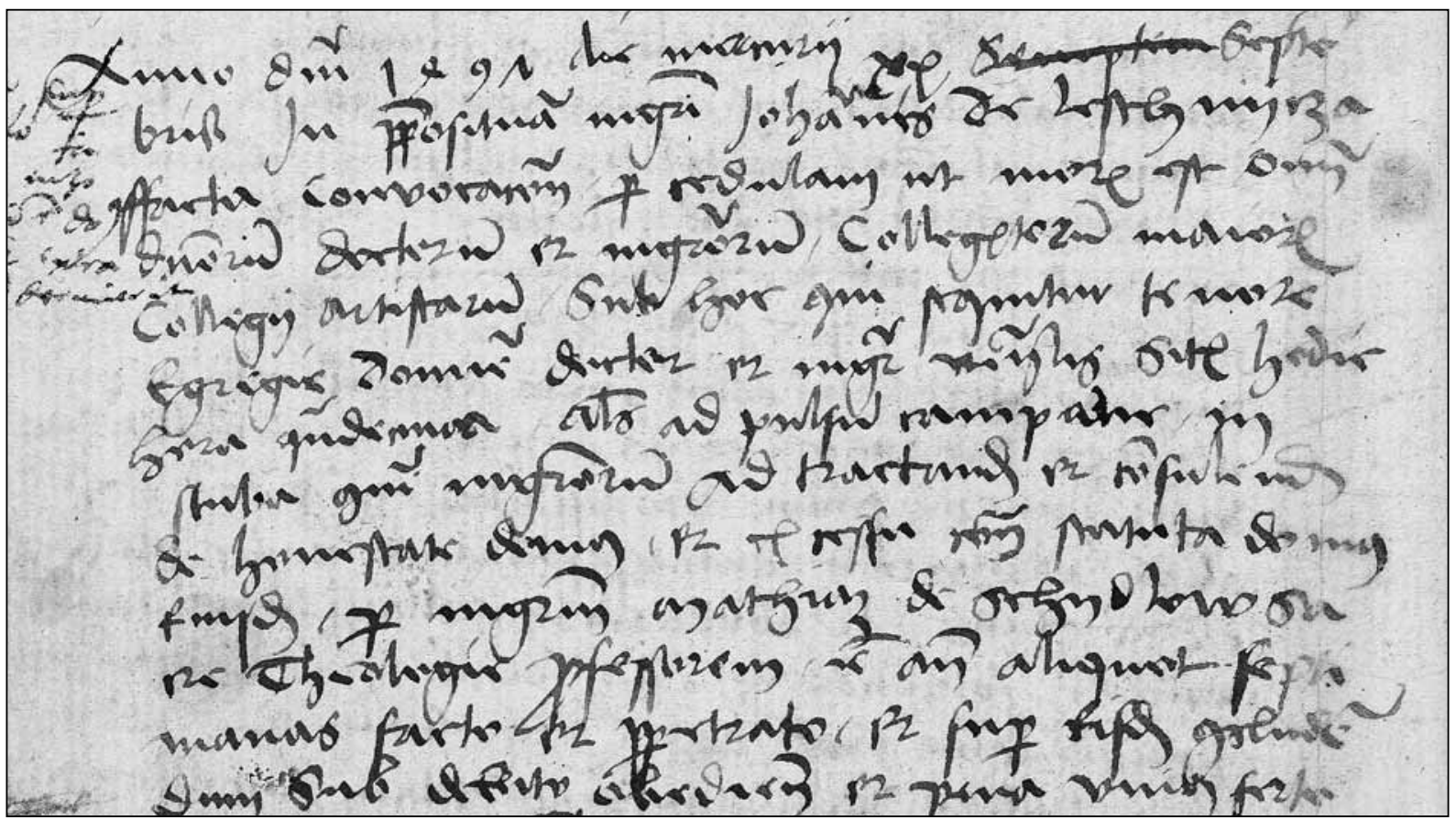

Il. 16: Autograf Jana z Leśnicy $(L C, \mathrm{~s} .38)$

${ }^{64}$ Formularz kilku analogicznych podpisów w rachunkach kapituły św. Floriana: Ita est. Ego magister Nicolaus Mikosz de Cracovia ad mandatum tocius capituli protunc presidens racioni annotari (AUJ rkps 177, s. 18-19) oraz cytowane wyżej subskrypcje Barnarda z Biskupiego (cz. B, nr 12).

${ }^{65}$ Glosy, które identyfikuję z Janem, znajdują się m.in. na k. 102v: Probatur in ista disctinctione [...], 105r: Et ita hic generans et genitum solum distinguuntur relative [...], 163v: Ista pars dividitur in tres [...], Albertus. Augustinus arguit [...], 190v: Hic prosequitur [...], Quia equalitas [...], 226r: Albertus. In veritate Augustinus non dat totam causam [...], 378v: Alexander. Hoc verbum wlt [...], 395r: Ista pars dividitur in duas partes [...], 404r: Si voluntas Dei consideretur [...]. Podobnie w rkps BJ 1519, k. 9r: Tho <mas $>$ de Ar<gentina $>$. Nec eciam (?) Philosophus alicubi videtur negare [...], 313v: Pe $<$ trus $>$ de $T<$ arantasia $>$. Voluntas potest dici tripliciter [...]. 


\section{Jan z Pilicy}

autografy w $L C$ : s. 29.

daty: 9 VII 1476, prepozyt: Jan z Pilicy.

inne przykłady autografów: BJ rkps 263, k. 37ra-rb ${ }^{66}$, 41va-42ra (z wyjątkiem wtrętu obcej ręki u dołu kolumny 41vb), 49va, 50va, 51va ${ }^{67}$; BJ rkps 2187, k. 227v: Expliciunt [...] per Johannem de Pylcza [...], k. 277v: [...] per me Johannem Petri de Pylcza artium baccalarium [...].

kariera uniwersytecka: student 1456e, bakałarz 1458, magister sztuk wyzwolonych 1468, bakałarz biblijny 1473, licencjat 1484 i doktor teologii 1484/1485, profesor na Wydziale Teologii 1485, senior Bursy Bogatych 1469-1470, prepozyt Kolegium Większego 1473h (?), 1476e, 1493e, prowizor Kolegium 1474e, 1486e, wiceprowizor (za Jana Welsa z Poznania) 1474h, kanonik kolegiaty św. Floriana przed 1484, tamże kustosz 1490 i dziekan 1491, prowizor Bursy Ubogich 1490, dwukrotny dziekan Wydziału Sztuk 1475h, 1484h, dwukrotny rektor 1490h, 1491e, wicekanclerz Uniwersytetu 1493-1496, zm. przed 31 III 1498 (LC, s. 29; BJ rkps 2219, k. 29v-30v, 37r, 46r; M I 56e/045; NKP 58/47B, 68/2M; Statuta Bursae Longini, s. LXX; PSB 10, s. 468; Bukowski, Rachunki 2, s. 691, przyp. 56 — tam wiadomości o karierze pozauniwersyteckiej i dalsza literatura).

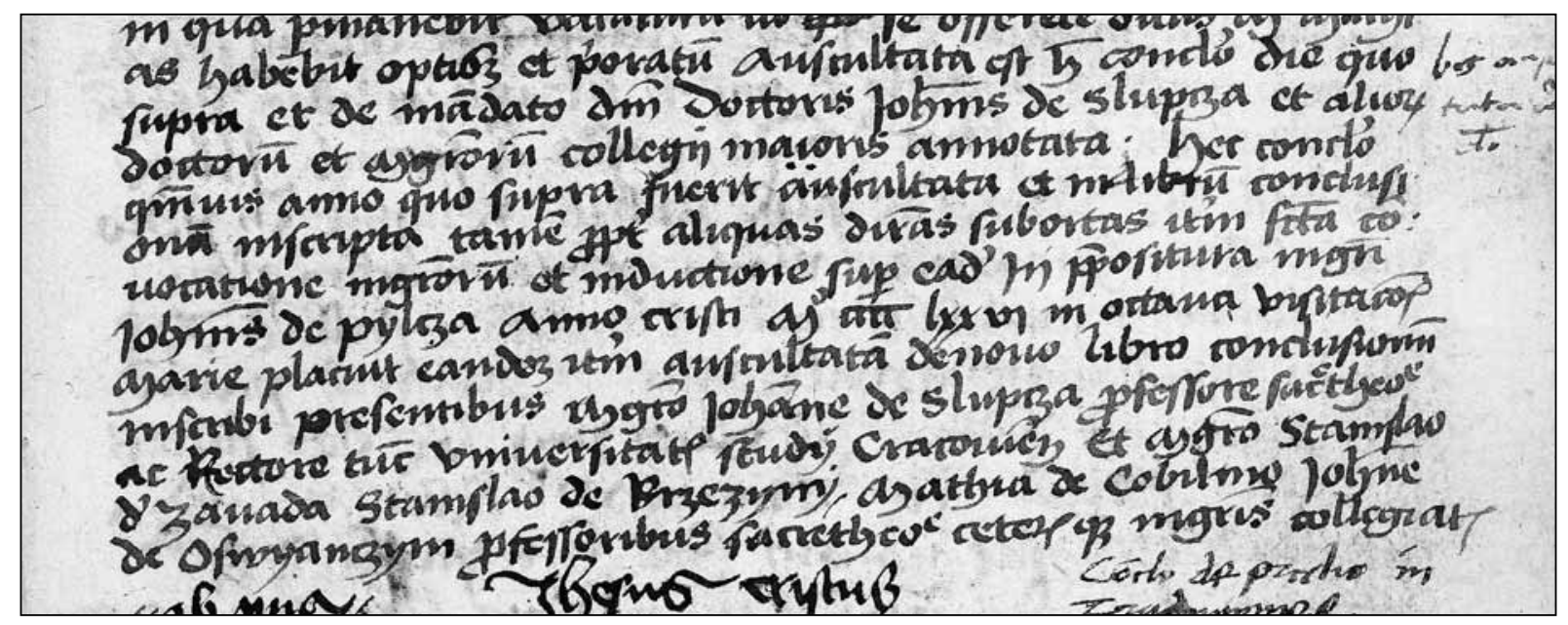

Il. 17: Autograf Jana z Pilicy (LC, s. 29)

\footnotetext{
${ }^{66}$ Autograf zidentyfikowany przez Wydawców, Najstarsza księga promocji, s. XVI.

67 Trzy ostatnie wpisy odnoszą się do egzaminów magisterskich, a Jan z Pilicy wnosił je do księgi promocji jako wicekanclerz uniwersytetu.
} 


\section{Jan ze Slupcy (z Kowali)}

autografy w $L C$ : s. 4.

daty: 22 V 1439, prepozyt: nieznany.

inne przykłady autografów: BJ rkps 258, s. 178-179, 287-288a ${ }^{68}$; BJ rkps 263, k. 16va ${ }^{69}$; BJ rkps 1347 , k. 43r: explicit [...] per manus Johannis de Slupcza (podobizna karty reprodukowana w: M. Kowalczyk, Colligite fragmenta, il. 9); BJ rkps 1354, k. 1r-13vet sqq.; BJ rkps 2367, k. 312r-322v et passim. kariera uniwersytecka: student 1429h, bakałarz 1432, magister sztuk wyzwolonych 1433, bakałarz teologii (biblijny) 1440-1441, licencjat teologii w listopadzie 1451, doktor teologii w lutym 1452, w Kolegium Większym co najmniej od 1439, profesor matematyki i astronomii na katedrze fundacji Jana Stobnera 1439, kantor kapituły św. Floriana i proboszcz w Olkuszu 1440, skarbnik Kolegium Większego 1465e, prowizor Kolegium Większego 1465h, czterokrotny dziekan Wydziału Sztuk 1439e, 1449h, 1476e, 1476h, dziekan Wydziału Teologii 1460h(?), 1465, trzykrotny rektor 1452h, 1476e, 1476h, wicekanclerz Uniwersytetu 1487h, zm. 2 VIII 1488, legował Uniwersytetowi swój księgozbiór ( $L C$, s. 4; BJ rkps 2219, k. 6r, 11r; M I 29h/100; NKP 32/21B, 33/31M; PSB 10, s. 476-478; Bukowski, Rachunki 2, s. 677, przyp. 15 - tam wiadomości o karierze pozauniwersyteckiej i dalsza literatura).

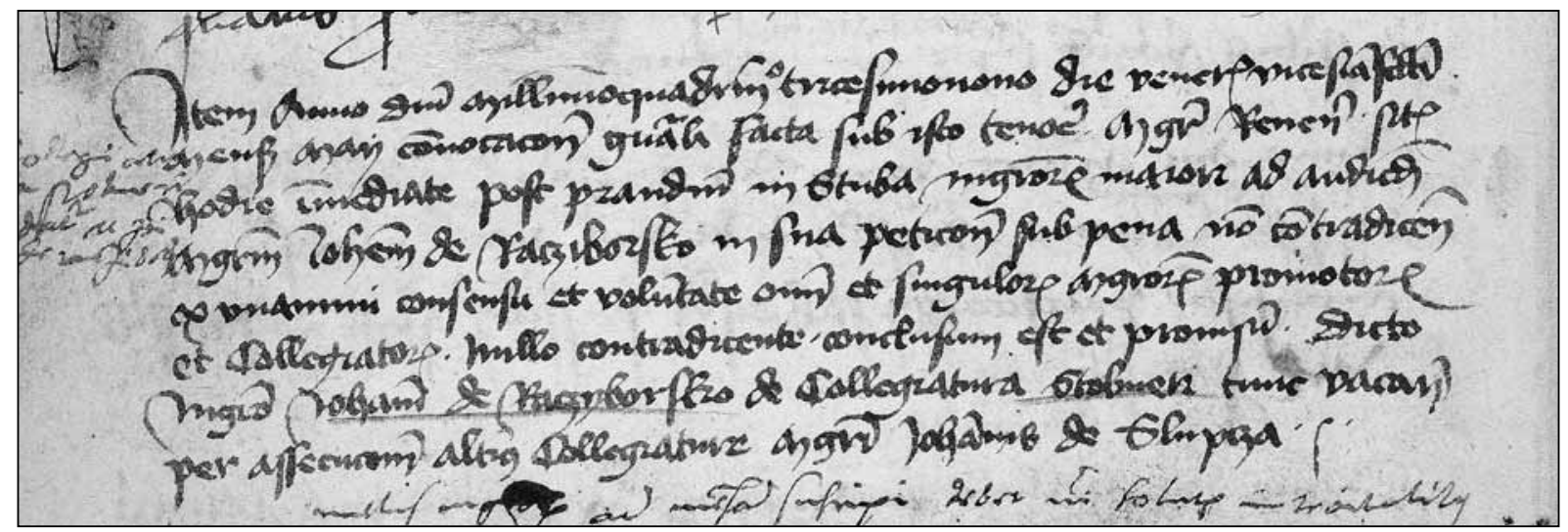

Il. 18: Autograf Jana ze Słupcy $(L C$, s. 4)

\footnotetext{
${ }^{68}$ Autografy zidentyfikowane przez Wydawców, Metryka, t. 1, s. 242, 383.

${ }^{69}$ Autograf zidentyfikowany przez Wydawców, Najstarsza księga promocji, s. XVI.
} 


\section{Maciej z Labiszyna}

autografy w $L C$ : s. 7.

daty: 26 VIII 1441, prepozyt: Maciej z Łabiszyna.

inne przykłady autografów: BJ rkps 1390, k. 227v: Explicit [...] per manus Mathie Labischin. Do autografu w $L C$ paleograficznie bardziej zbliżone są zapiski biograficzne i biblioteczne Macieja w rękopisach BJ 1390, k. 285v-286v, Ir-IIIv, wyklejki i deska dolnej okładki oraz BJ 1456, wyklejki obydwu okładek, Ir-v, 1r-v, 430r-v, IIr-v. Podobizny wybranych kart z rękopisu BJ 1390 reprodukowane są w artykule L. Nowak, Zapiski Macieja z Łabiszyna w rękopisie Biblioteki Jagiellońskiej 1390. Edycja wybranych fragmentów, „Acta Mediaevalia”, 20, 2007, s. 321-324.

kariera uniwersytecka: student 1419e, bakałarz 1420, magister sztuk wyzwolonych 6 II 1425, bakałarz teologii (biblijny) 5 II 1434, sentencjariusz 1443, licencjat 10 II 1445 i doktor teologii 3 XI 1446, kolegiat Kolegium Królewskiego krótko po 20 IV 1427, prepozyt Kolegium Królewskiego 1429, 1441e, dziekan Wydziału Sztuk 1431h, kustosz kapituły św. Floriana 1439, dziekan tamże 1449, członek komisji rektorskiej do rewizji statutów i przywilejów 1440-1441, rektor Uniwersytetu 1449e, zm. po 26 II 1452, najpóźniej w 1453 (LC, s. 7; ADLOP, 1, s. 1-20; J. Zathey, Biblioteka Jagiellońska w latach 1364-1492, s. 41; M I 19e/059; NKP 20/18B, 25/5M; Kowalczyk, Wypominki, s. 527 [191]; PSB 19, s. 27; PoczetR., s. 77; Markowski, DzWT, s. 155-158; L. Nowak, Zapiski Macieja z Łabiszyna w rękopisie Biblioteki Jagiellońskiej 1390, s. 315, 326 n. oraz taż, Zapiski Macieja z Łabiszyna w rękopisie Biblioteki Jagiellońskiej 1456. Edycja wybranych fragmentów, „Acta Mediaevalia”, 22, 2009, s. 496, 498).

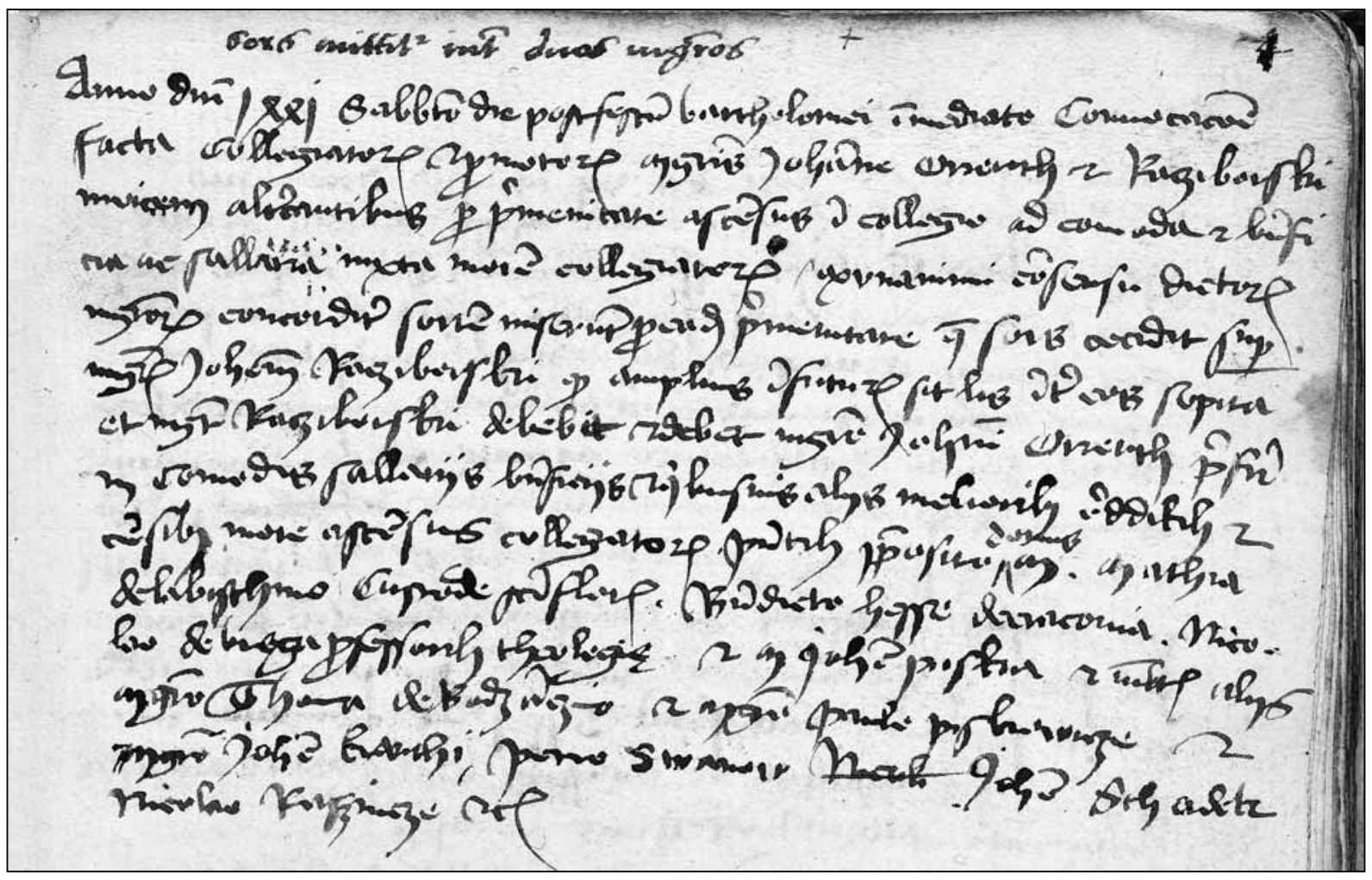

Il. 19: Autograf Macieja z Łabiszyna ( $L C$, s. 7) 


\section{Maciej z Sąspowa}

autografy w $L C$ : s. 8-9.

daty: 7 XII 1443, prepozyt: nieznany.

inne przykłady autografów: AUJ rkps 377b, s. 3 (z formułą subskrypcyjną per me), 12; BJ rkps 2313, k. 343v: Finite [...] per manus magistri Mathie de Sanspow; k. 466v: Manus Mathie de Sanspow finivit; podobizna autografu Macieja z rkps BJ 2241, k. 314r reprodukowana w: M. Kowalczyk, Colligite fragmenta, il. 21.

kariera uniwersytecka: student 1426, bakałarz 1432, magister sztuk wyzwolonych 1437, bakałarz teologii 1447, sentencjariusz ok. 1455-1457, licencjat przed 1458, doktor teologii 28 XI 1460, w Kolegium Większym co najmniej od 1443, prowizor Kolegium 1464h, konsyliarz Kolegium 1470, kanonik kolegiaty św. Floriana co najmniej od 1451, prowizor dóbr tamże 1468, 1470, dwukrotny dziekan Wydziału Sztuk 1445e, 1458h, dziekan Wydziału Teologii 1463, wicerektor Uniwersytetu 1467, zm. po 15 III 1472 (LC, s. 8-9; BJ rkps 2219, k. 5v, 8r, 15r, 21r; M I 26/134; NKP 32/14B, 37/8M; CDUJ, t. 2, nr 127, s. 55 n.; PSB 19, s. 36; Bukowski, Rachunki 1, s. 25, przyp. 5 oraz tenże, Rachunki 2, s. 677, przyp. 17 - tam dalsza literatura).

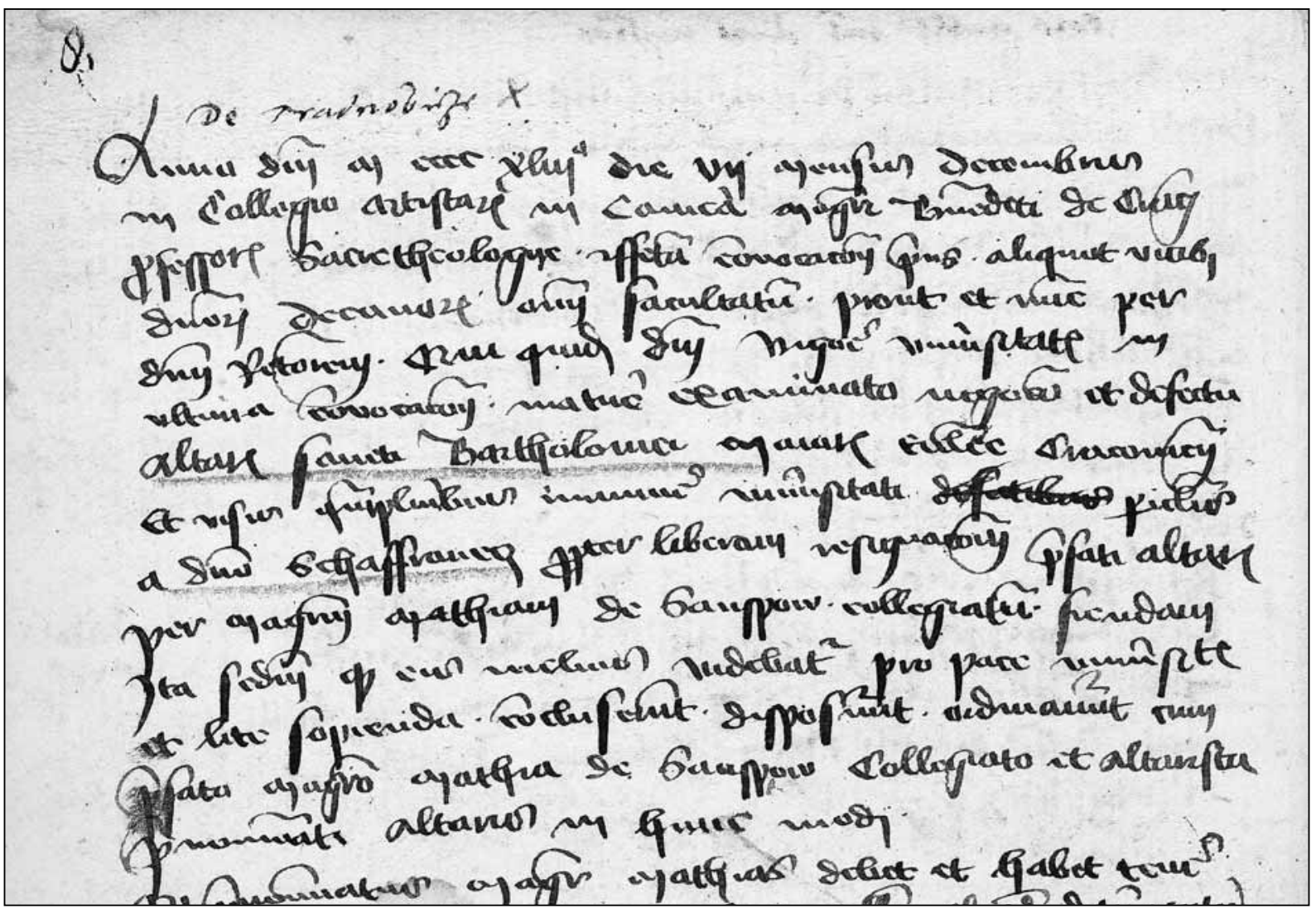

Il. 20: Autograf Macieja z Sąspowa $(L C$, s. 8$)$ 


\section{Marcin Biem z Olkusza}

autografy w $L C$ : s. 42-43.

daty: 2 III 1500, prepozyt: Stanisław ze Srebrnej Górki.

inne przykłady autografów: AUJ rkps 57, s. 1 (z formułą subskrypcyjną ego), 82-84; BJ rkps 249, k. 29v-30r; BJ rkps 263, k. 45ra (glosa przy własnym nazwisku, opatrzona formułą subskrypcyjną Hoc scripsi 1538), 54va, 55rb-56ra; BJ rkps 1514, k. 394v (kolofon bez imienia); BJ rkps 1515, k. 302r (kolofon) oraz liczne glosy w całym kodeksie; podobizna autografu Marcina z BJ rkps 1964, k. 170r reprodukowana w: W. Semkowicz, Paleografia łacińska, wyd. II popr., Kraków 2002, s. 362, ryc. 126; zob. też reprodukcje not własnościowych w inkunabułach BJ: Wisłocki, Incunabula, s. 76 n. et passim ${ }^{70}$.

kariera uniwersytecka: student 1486h, bakałarz 1488, magister sztuk wyzwolonych 1491, bakałarz biblijny przed styczniem 1507, sentencjariusz 1513, licencjat 1516, doktor teologii 22 I 1517, na Wydziale Sztuk od 1491, kolegiat Kolegium Mniejszego 1496, w Kolegium Większym od marca 1500, prepozyt Kolegium 1500e, 1526h (wiceprepozytem był za niego Mikołaj z Szadka), kantor kolegiaty św. Floriana i proboszcz w Olkuszu 31 I 1507-1520, kanonik kapituły św. Floriana 1520, proboszcz kościoła św. Mikołaja od października 1526, w listopadzie 1534 kolegiaci odmówili mu prawa do powrotu stamtąd do Kolegium i do awansów na beneficja kolegialne, dziekan Wydziału Sztuk 1500h, trzykrotny dziekan Wydziału Teologii 1521h, 1528h, 1538e; konsyliarz rektora 1500, 1527, prowizor Bursy Ubogich w kwietniu 1524, 1529, 1533, wicekonserwator praw Uniwersytetu 1534-1535, 1538h, dziewięciokrotny rektor Uniwersytetu 1522h-1523h, 1527e, 1530e, 1530h, 1534h-1535h, wicekanclerz Uniwersytetu 1538-1540, zm. 9 XI 1540 (AUJ rkps 57, s. 42; LC, s. 48-50, 69, 72-73, 79; Diariusz Marcina Biema z Olkusza; M I 86h/237; NKP 88/104B, 91/4M; AR I, s. 851; PSB 2, s. 68 n.; Markowski, DzWT, s. 209 n.; PoczetR., s. 130).

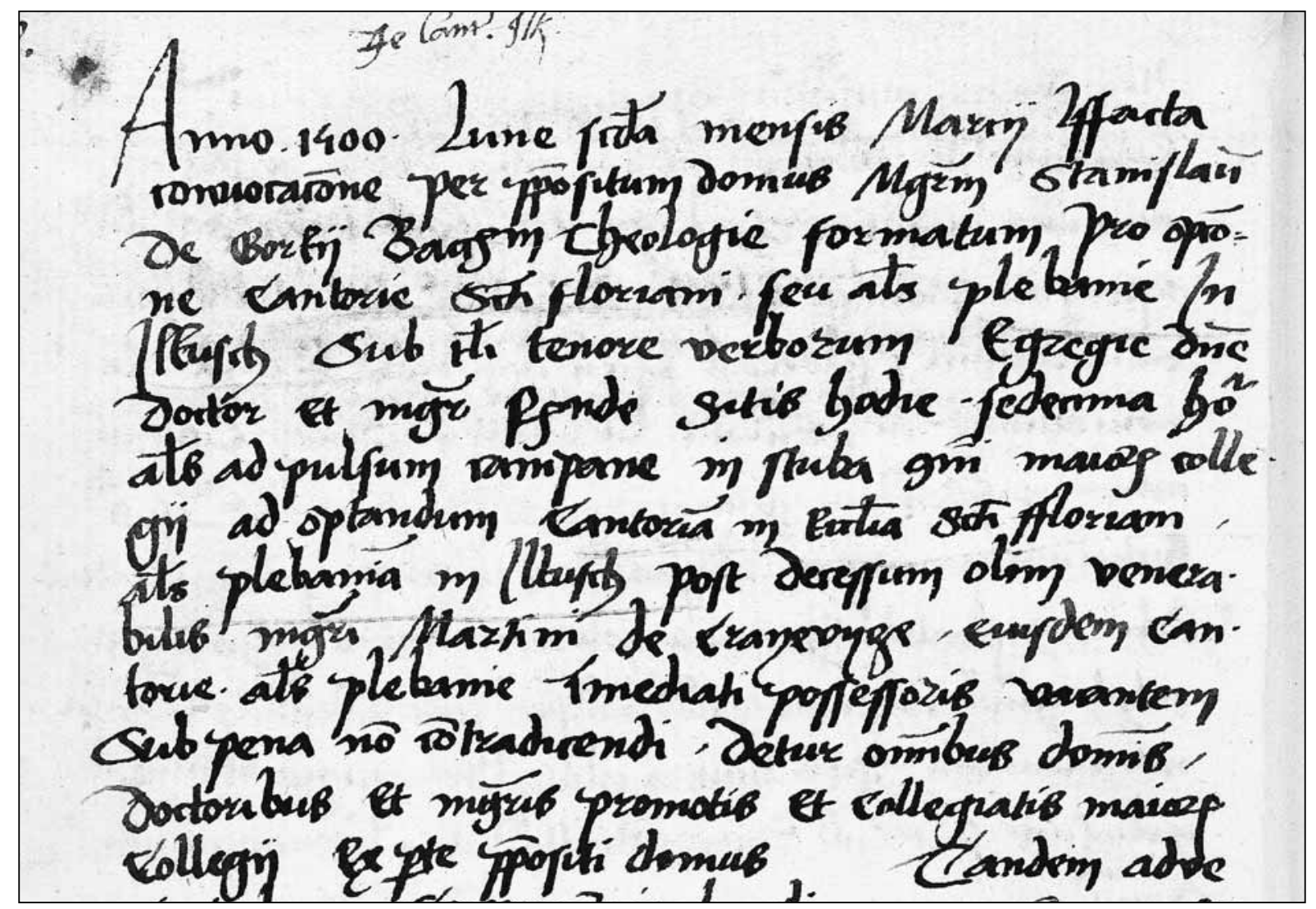

Il. 21: Autograf Marcina Biema z Olkusza ( $L C$, s. 42)

${ }^{70}$ Wydaje się, że autografem Marcina nie jest natomiast BJ rkps 1853, dotąd za autograf uważany (np. Catalogus, t. 9, s. 272). 


\section{Michał z Biestrzykowa (Parisiensis)}

autografy w $L C$ : s. $68-69$.

daty: 15 V i 2 VI 1514, prepozyt: Michał z Biestrzykowa.

inne przykłady autografów: AUJ rkps 57, s. 86 (z formułą subskrypcyjną ego); BJ rkps 249, k. 31v, 32v-33r; BJ rkps 263, k. 52ra-va, 56vb-57rb.

kariera uniwersytecka: student Uniwersytetu Krakowskiego 1468h, bakałarz (1473), licencjat i magister sztuk wyzwolonych Uniwersytetu Paryskiego 1475, student w Ingolstadt 1478, magister assumptus w Krakowie 1485, wykładowca na Wydziale Sztuk od 1487h, bakałarz teologii w Paryżu, doktor tamże?, w Krakowie inkorporowany do Wydziału Teologii przed 15 XII 1505?, doktor teologii (nostryfikowany?) 12 II 1507, senior Bursy Jerozolimskiej w Krakowie 1488-1491, kolegiat Kolegium Mniejszego 1491, kolegiat Kolegium Większego 1495, prepozyt Kolegium Większego 1495e, 1514e, kanonik kolegiaty św. Floriana 1509, skarbnik Kolegium 1512-1515, dwukrotny dziekan Wydziału Sztuk 1495h, 1501h, członek komisji do reformy Bursy Jerozolimskiej 1495, prokurator Uniwersytetu 1496-1500, dwukrotny rektor Uniwersytetu 1513h, 1514e, zrzekł się katedry teologii przed 3 III 1515, odszedł z uniwersytetu, wicekonserwator praw Uniwersytetu 1516, zm. 12 II 1520 (LC, s. 68; BJ rkps 2219, k. 54r, 105v, 114v-116r, 119v; M I 68h/218; NKP 85/13Ma; CUC, s. 85; PSB 20, s. 621 n.; Wypisy źródłowe do dziejów Wawelu z archiwaliów kapitulnych i kurialnych krakowskich 1516-1525, oprac. B. Przybyszewski, Kraków 1970, s. 5; Bukowski, Rachunki 2, s. 665, nr 11 - tam dalsza literatura).

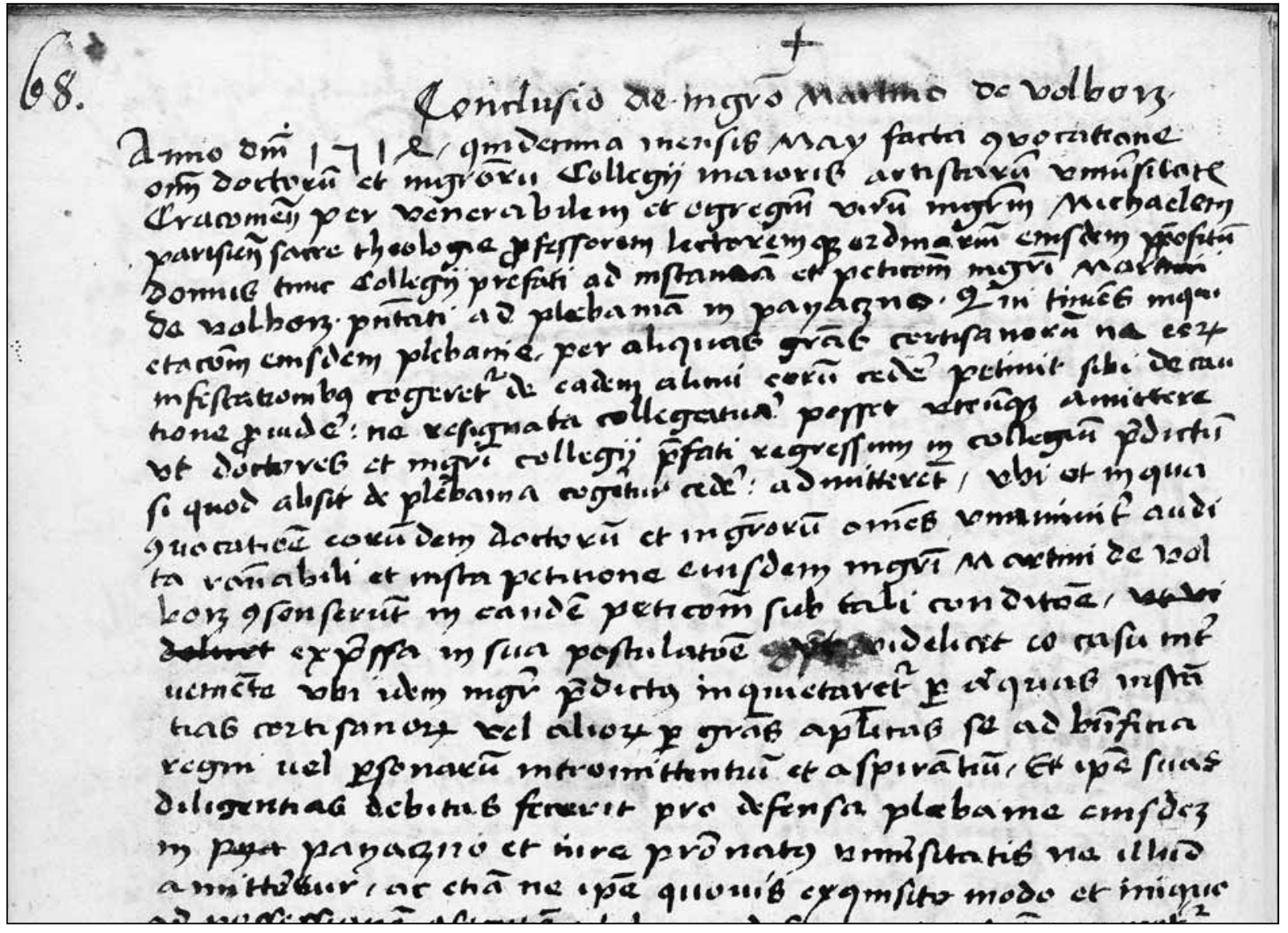

Il. 22: Autograf Michała z Biestrzykowa $(L C, \mathrm{~s} .68)$ 


\section{Michał Sternberg z Lgoty (z Oleśnicy)}

autografy w $L C$ : s. 53-57.

daty: 28 VII - 22 IX 1507 oraz 5 VI 1507, prepozyt: Michał Sternberg z Lgoty.

inne przykłady autografów: AUJ rkps 57, s. 87, 89 (z formułą subskrypcyjną ego); BJ rkps 263, k. 61va-62ra (wpisy z dziekanatu Michała Falkenera z Wrocławia), 74ra-vb (nazwiska bakałarzy), 74va (nazwiska bakałarzy); BJ rkps 1518 i $1519^{71}$.

kariera uniwersytecka: student 1486e, bakałarz 1490, magister sztuk 1501, bakałarz biblijny 1517, bakałarz sentencjariusz 1521, bakałarz format 1523, licencjat teologii 1524, profesor teologii 1526, kolegiat Kolegium Mniejszego 1504, senior Bursy Ubogich 1505, do Kolegium Większego wszedł ok. 12 III 1507, prepozyt Kolegium Większego 1507e, kanonik św. Floriana 151572, dwukrotny dziekan Wydziału Sztuk 1509h, 1519h, zm. 1 IX 1527, ofiarował Uniwersytetowi legat na rozbudowę biblioteki (AUJ rkps 57, s. 87, 89; LC, s. 53-57; BJ rkps 2219, k. 66v ${ }^{73}$; Diariusz Marcina Biema z Olkusza; M I 86e/069; NKP 90/23B, 1501/2M; AR I, s. 1153; LD, s. 499 n.; CUC, s. 475; CDUC, t. 4, nr 337, s. 57 n.; Wisłocki, Incunabula, s. 478 n.; Barycz, Historia UJ, s. 675).

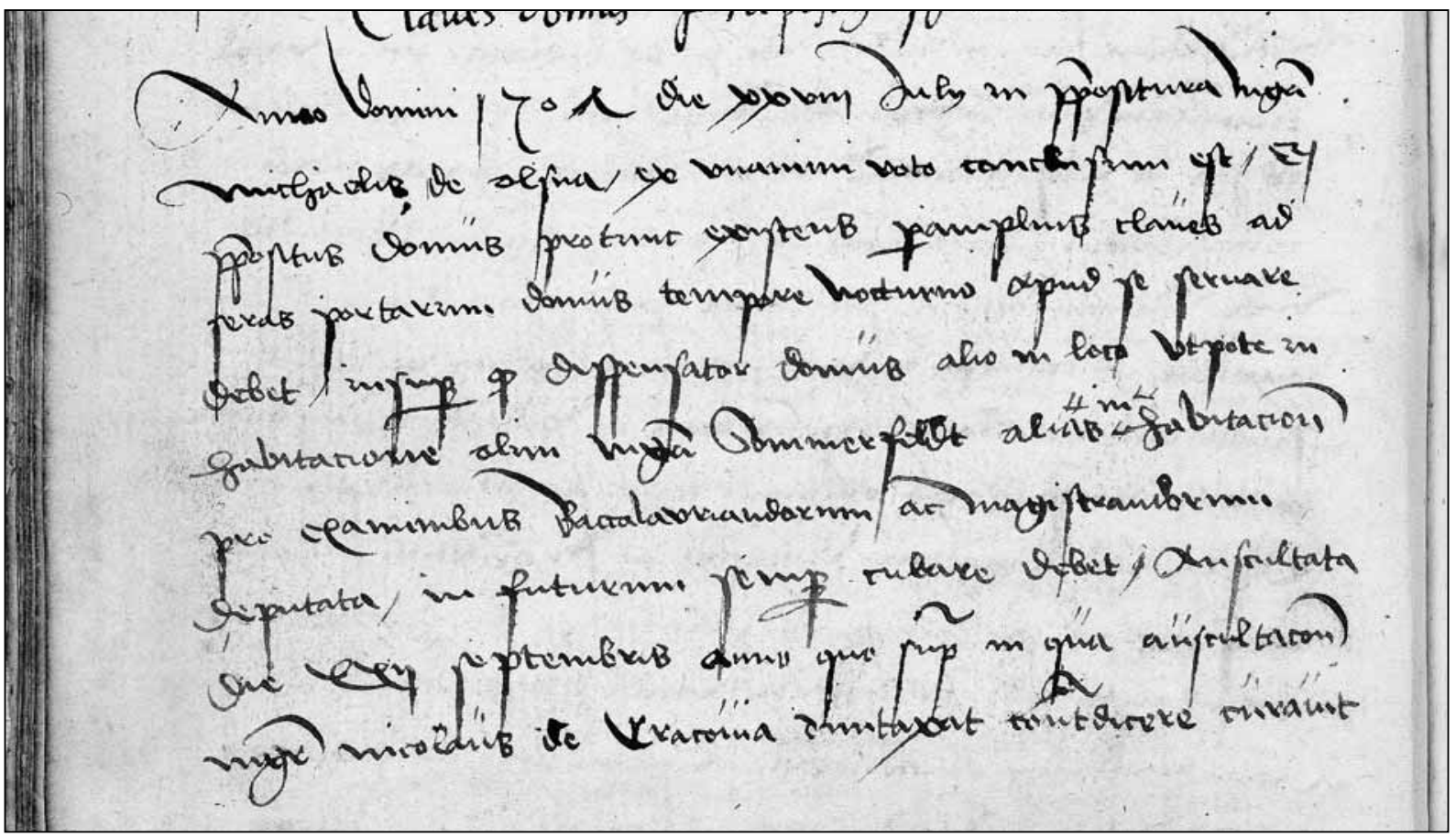

Il. 23: Autograf Michała Sternberga z Lgoty (z Oleśnicy) ( $L C$, s. 54)

\footnotetext{
${ }^{71}$ Spod ręki Michała wyszły nieliczne glosy komentarza w rkps BJ 1518, np. k. 222r: Secundum quem modum Greci loquuntur [...], 264r: Quia non erat tempore suo usitatum [...], i BJ 1519, np. k. 158r: Quod scire tenetur pro tempore [...], 170r: Consequenter (?) ergo complectitur [...], 313r: Richardus. Naturalis voluntas [...]; 328r: Vel in ordine ad preceptum [...].

72 Za Diariuszem Marcina Biema z Olkusza — kwiecień 1515.

${ }^{73}$ Zapis źródłowy brzmi: Item feria sexta alias in crastino sancti Gregorii magister Michael de Olszna obtulit communitati Maioris Collegii tres fertones racione suorum introitalium sub anno 1507. Przypuszczalnie pomyłka w zapisie daty, gdyż w 1507 r. święto św. Grzegorza papieża przypadało w piątek, a nie w czwartek, jak sugerowałaby zapiska.
} 


\section{Michał z Wielunia}

autografy w $L C$ : s. 31 .

daty: 8 II 1480, prepozyt: Michał z Wielunia.

inne przykłady autografów: niepotwierdzone; por. AUJ rkps 377a, s. 19 (pierwsze trzy zapiski z 1483 r.); BJ rkps 263, k. 40va-vb. Spod tej samej ręki wyszły noty i wskazówki (maniculae) w inkunabułach BJ, których Michał był właścicielem: BJ Inc. 670 (glosy drobną kursywą gotycko-humanistyczną z charakterystycznym krojem liter ,g”, „d”, „," na k. $\mathrm{g}^{5} \mathrm{r}-\mathrm{g}^{8} \mathrm{v}$ ) ${ }^{74}$ i BJ Inc. 1966 (na przedniej karcie ochronnej nota: Embrocatio sit casus [...], k. 11r: Aliud expectum).

kariera uniwersytecka: student 1466h, bakałarz 1470, magister sztuk wyzwolonych 1474, bakałarz dekretów przed 1481, do Kolegium Większego wszedł w 1479e, prepozyt Kolegium Większego 1479h, członek komisji do reformy Wydziału Sztuk 1480, dziekan Wydziału Sztuk 1480h, w 1484 wyjechał na pielgrzymkę do Ziemi Świętej, kilkakrotnie w niewoli i kilkakrotnie wykupywany, zm. 1487 na Rodos (LC, s. 31; BJ rkps 2219, k. 35r; M I 66h/100; NKP 70/74B, 74/1M; PSB 20, s. 627 n.; Bukowski, Rachunki 2, s. 700, przyp. 71 - tam dalsza literatura).

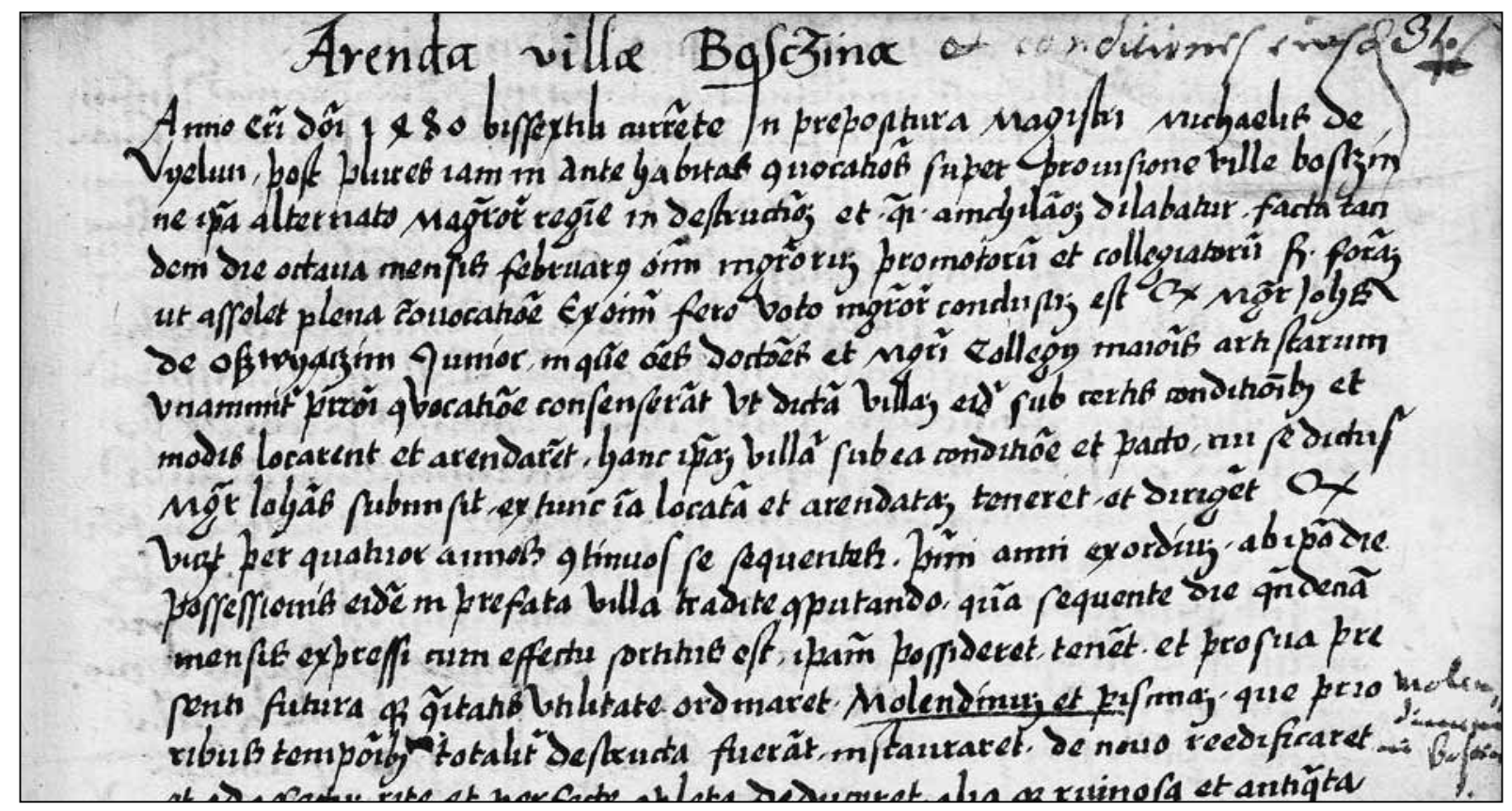

Il. 24: Autograf Michała z Wielunia ( $L C$, s. 31)

${ }^{74}$ G. Rosińska, Scientific writings, nr 1253 wzmiankuje prognostyk (Iudicium eclipsis Solis) autorstwa Michała z Wielunia w rękopisie Wiedeń, Österreichische Nationalbibliothek, Lat. 10354, k. 78r-80v. Do tego rękopisu nie udało mi się dotrzeć. 


\section{Stanisław Bylica z Olkusza}

autografy w $L C$ : s. 65-67.

daty: 21 V 1513, prepozyt: Stanisław Bylica z Olkusza.

inne przykłady autografów: niepotwierdzone ${ }^{75}$; por. BJ rkps $249, \mathrm{k} .17 \mathrm{v}-19 \mathrm{v} ; 22 \mathrm{v}-23 \mathrm{r}$; BJ rkps 263 , k. 51va-vb, 52vb-53rb; por. także marginalia w rękopisach i drukach jego proweniencji: BJ rkps 1540, k. 10r, 41v-42r, 124v et passim (żywa pagina, noty marginalne na przestrzeni całego rękopisu); BJ Inc. $1049, \mathrm{k} . \mathrm{a}^{3} \mathrm{v}-\mathrm{a}^{4} \mathrm{v}, \mathrm{a}^{6} \mathrm{r}-\mathrm{v}, \mathrm{f}^{5} \mathrm{r}-\mathrm{f}^{6} \mathrm{v}, \mathrm{L}^{3} \mathrm{r}-\mathrm{L}^{8} \mathrm{v}, \mathrm{S}^{4} \mathrm{r}-\mathrm{S}^{5} \mathrm{v}$ et passim.

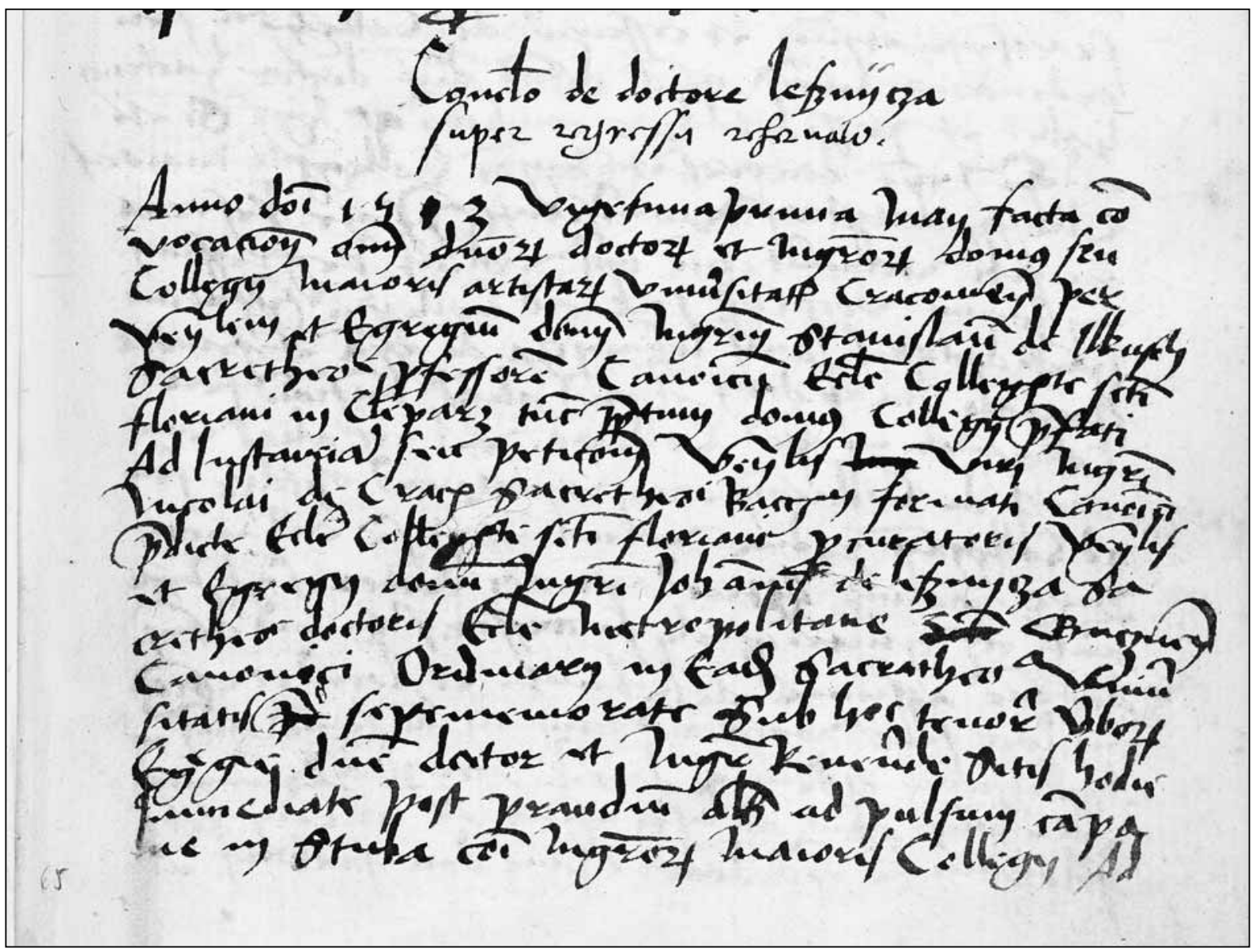

Il. 25: Autograf Stanisława Bylicy z Olkusza ( $L C$, s. 65)

\footnotetext{
${ }^{75}$ Horoskop autorstwa Stanisława Bylicy w rękopisie BJ 579, s. 27-51 składa się z tabel astronomicznych i cyfr (jedynym wyjątkiem jest karta tytułowa oraz nazwy miesięcy) i nie występuje tam pismo kursywne. Z tych względów miał małe znaczenie dla ustalenia ręki Stanisława. Ze Stanisławem Bylicą można powiązać liczne glosy komentarzy do Sentencji Piotra Lombarda: w rękopisie BJ 1515 glosy wpisane czarnym atramentem (obok glosy komentarza Marcina Biema z Olkusza), m.in. na k. 1r: Hic tangitur illud dictum [...]; In quo ostendit Deum esse primum principium [...], 2r: Nota, quod aliqua sunt verba [...], 2v: Non ergo errat Arystoteles [...], 9v: Secundum beatum Augustinum [...], Ex hac littera colligitur [...], 30r: Nota, quod dyabolus tempore martirum egit violenter [...], 81r: Notandum: Tractatores katholici quandocunque locuntur [...], 85r: Notandum, quod capiendo ymaginem pro essencia Trinitatis [...], oraz w rękopisach BJ 1518, k. 405v: Permissio in nobis est volicio remissa [...] i BJ 1519, k. 170r: Id est potestas faciliter movens voluntatem [...]. Być może on był również pisarzem tekstu głównego komentarza Piotra z Tarantazji do I księgi Sentencji Piotra Lombarda w rękopisie BJ 1540. Pismo tamtejsze nosi wprawdzie cechy gotyckie i wykazuje niewiele pokrewieństw z pismem Stanisława w $L C$ oraz w rękopisach wskazanych jako przykłady, gdzie mamy do czynienia z pismem kursywnym o cechach humanistycznych. Można niemniej zaobserwować zbieżne tendencje obydwu pism, np. maniera zapisu litery „g”.
} 
kariera uniwersytecka: student 1476h, bakałarz 1478, magister sztuk 1484, bakałarz teologii (biblijny) 1500, doktor teologii 22 XI 1509, wykładowca na Wydziale Sztuk, kolegiat Kolegium Mniejszego 1490, w Bursie Ubogich (senior?) 1494, kolegiat Kolegium Większego 1497, prepozyt Kolegium Większego 1497h, 1513e i wiceprepozyt 1509h (za Tomasza z Obidzina), kantor kapituły św. Floriana i proboszcz w Olkuszu 1500-1506, kanonik kapituły św. Floriana 1506, dziekan Wydziału Sztuk 1495e, dziekan Wydziału Teologii 1512e, zm. 15 IX 1514 (LC, s. 50-51, 65; BJ rkps 2219, k. 69v, 98v, 104r, 112r; M I 76h/242; NKP 78/81B, 84/11M; AR I, s. 869; PSB, t. 3, s. 168)

\section{Stanisław z Zawady (z Pyskowic)}

autografy w $L C$ : s. 14.

daty: 11 VIII 1449, prepozyt: Paweł z Pyskowic.

inne przykłady autografów: BJ rkps 263, k. 22ra, 27ra; BJ rkps 1310, np. k. 78r, 129v, 133r, 155v, 289r, 349r (wielokrotne zmiany duktu; na tych kartach krój pisma najbardziej zbliżony do użytego w $L C$ ); BJ rkps 1429, k. 394r: 1468. Zawada; k. 406v: Anno 1468. Stanislaus Zawada; k. 506v: Explicit [...] per magistrum Stanislaum de Zawad (!), theologice (?) veritatis professorem (wielokrotne zmiany duktu i atramentu; na k. 335r-406v krój pisma najbardziej zbliżony do $L C$ ); BJ rkps 1701, k. 231v: Et est scripta [...] per doctorem Stanislaum de Zawada; BJ rkps 6394, nr 49 (z formułą subskrypcyjną per me $)^{76}$.

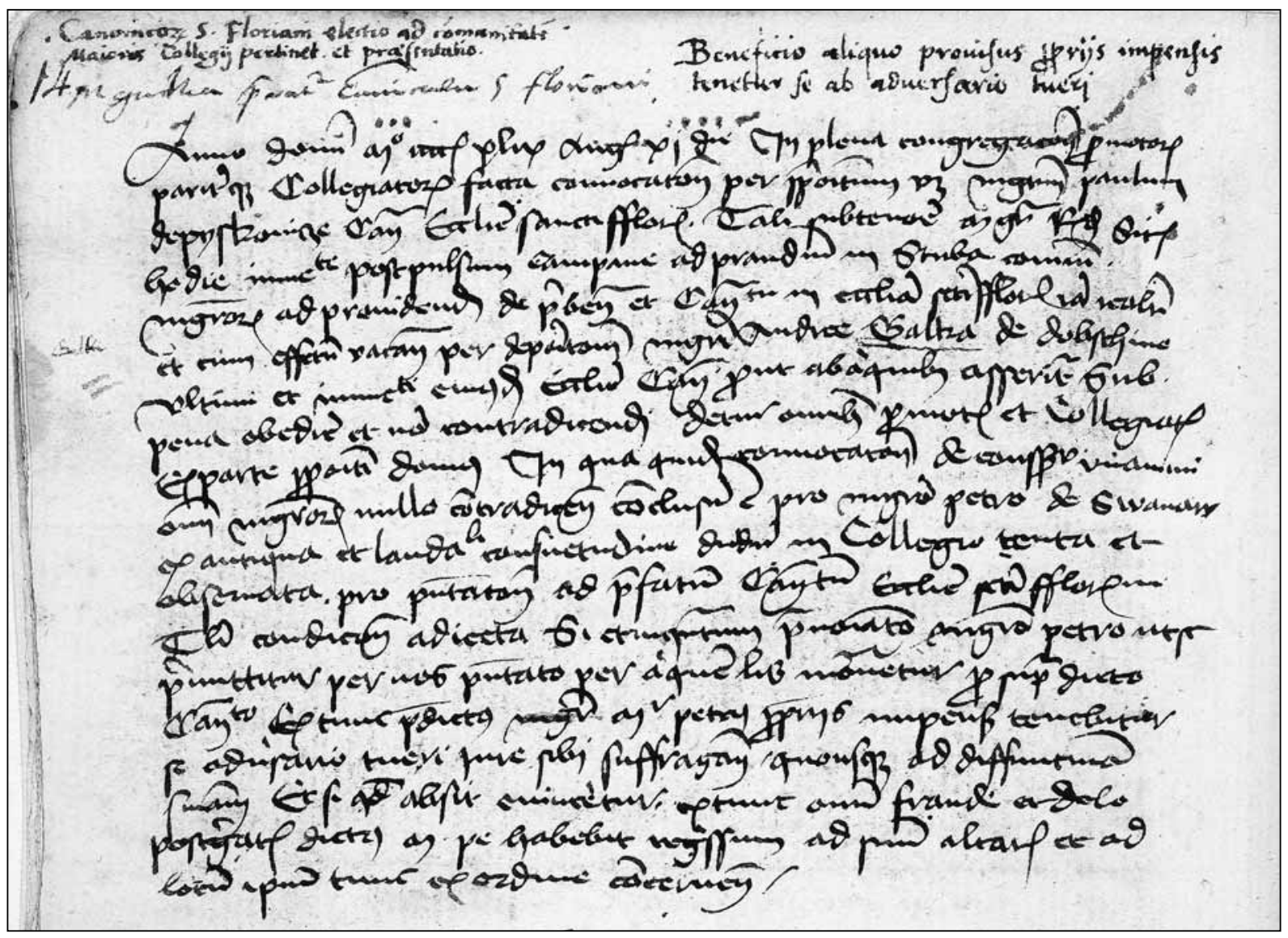

Il. 26: Autograf Stanisława z Zawady $(L C$, s. 14)

\footnotetext{
${ }^{76}$ Pismo Stanisława z Zawady występuje w kilku kodeksach z dziełami Pawła z Pyskowic lub pochodzących z jego biblioteki. Do takich zalicza się m.in. wzmiankowany w nocie BJ rkps 1310 (por. Catalogus, t. 8, s. 229 n.); BJ rkps 1534, z pismem bardzo zbliżonym do $L C$ na k. 6r., 86r-92r, 369v-370r, którego fragment ukończono 26 III 1444 r. (por. nota marginalna na k. 370r) —
} 
kariera uniwersytecka: krewny Pawła z Pyskowic, student 1436e, bakałarz 1440, magister sztuk wyzwolonych 1444, bakałarz biblijny ok. 1450, bakałarz format teologii 1464, doktor teologii 1467, profesor na kolegiaturze gramatyki z fundacji Mikołaja z Brzeźnicy i altarysta ołtarza św. Piotra i Pawła w kościele św. Anny III 1449, profesor na kolegiaturze z fundacji Szafrańców uposażonej altarią św. Bartłomieja w katedrze krakowskiej 1455-1464, kustosz kapituły kolegiaty św. Floriana 1473-1477 (ustąpił po 9 IX, a przed 16 XII 1477), kanonik tamże 1478 (rezygnacja przed 6 VII 1483), ponownie 1485, wykładowca zwyczajny teologii 1483 (AR I nr 913), prepozyt Kolegium Większego 1455h, 1471e, dwukrotny dziekan Wydziału Sztuk 1450h, 1460h, dziekan Wydziału Teologii 1470e, 1477h, wicedziekan tegoż IV 1483, wicerektor XII 1476 (za Jana ze Słupcy), III 1478 (za Macieja z Kobylina), dwukrotny rektor Uniwersytetu 1478e, 1478h, skarbnik (czego?) 1488, zm. 14 V 1491 (LC, s. 13, 14, 23; BJ 2219, k. 2r, 24r; M I 36e/039; NKP 40/11B, 44/10M; AR I nr 654, 913; CDUJ, t. 3, nr 238, 255, 273; PSB 42, s. 96 n.; Bukowski, Rachunki 2, s. 684, 685, 710 oraz przyp. 35 - tam dalsza literatura).

\section{Wojciech z Pniew}

autografy w $L C$ : s. 35-36.

daty: 2 XII 1489, prepozyt: Wojciech z Pniew.

inne przykłady autografów: AUJ rkps 57, s. 45, 85; AUJ rkps 177, s. 5 (z formułą subskrypcyjną ego), 6, 7 (ego), 8 (ego), 129 (per me), 189 (ego); BJ rkps 249, k. 5v-6r; BJ rkps 2458, k. 104r: Finis huius. Albertus de Pnÿewy.

kariera uniwersytecka: student 1469h, bakałarz 1473, magister sztuk wyzwolonych 1477, bakałarz dekretów 1489, bakałarz biblijny 1495, doktor teologii 1496 w Rzymie, nostryfikowany na Wydziale Teologii Uniwersytetu Krakowskiego 1498, senior Bursy Jerozolimskiej 1483, kolegiat Kolegium Mniejszego

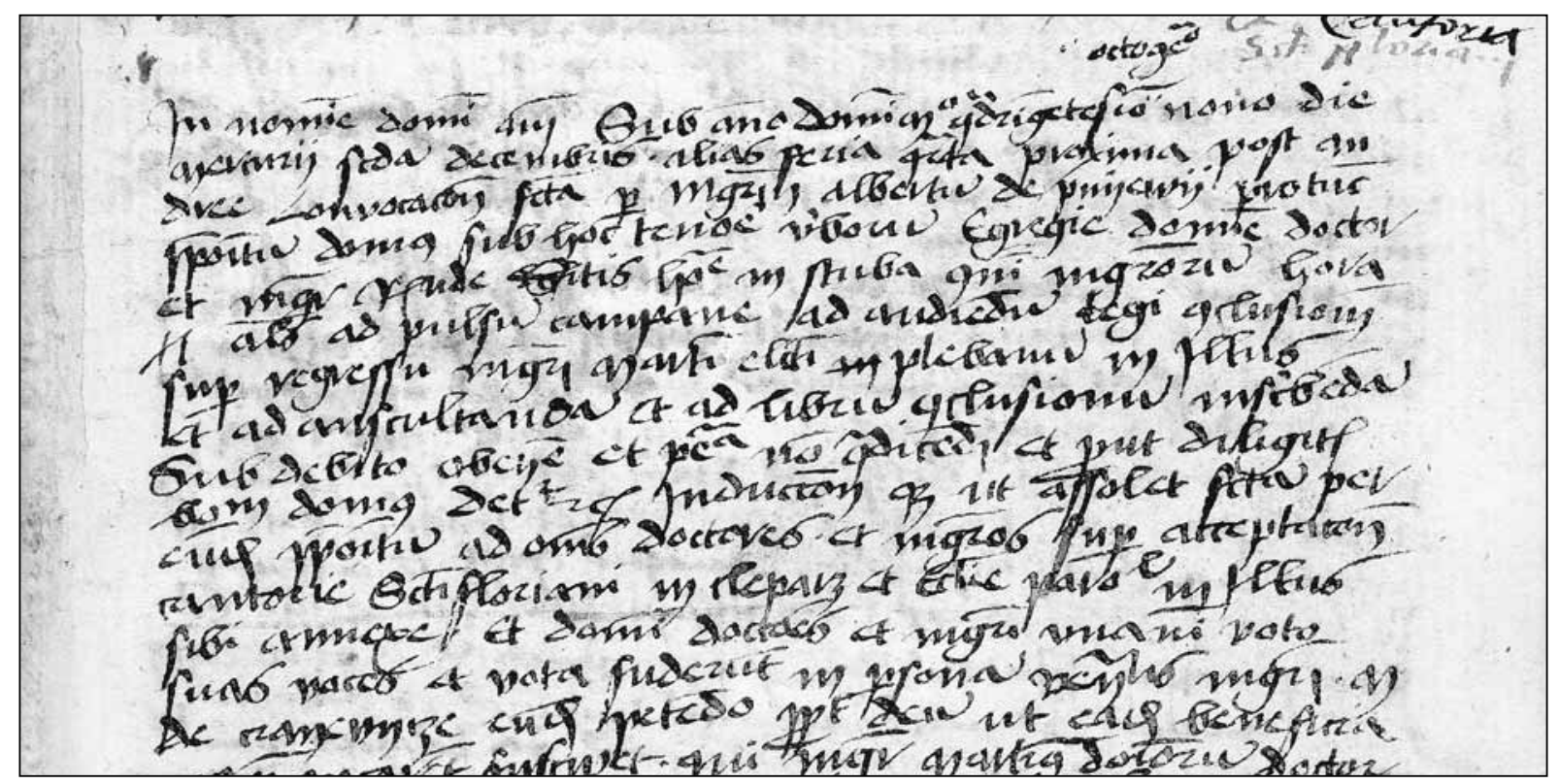

II. 27: Autograf Wojciecha z Pniew ( $L C$, s. 35)

jak się wydaje, Stanisław z Zawady przepisał tekst główny Sentencji Piotra Lombarda i znaczne partie komentarza, stosując różne dukty; BJ rkps 2246, k. 20r-21v, 85r-91v, 93v-97v, 107r-v, 109r, 140r, 285r-289r — pismo Stanisława często na zmianę z innym, uznawanym za autograf Pawła z Pyskowic. O autografach Pawła z Pyskowic w tych kodeksach zob. opis katalogowy rękopisu 1310 (j.w.) oraz Z. Włodek, Paweł z Pyskowic, „Materiały i Studia Zakładu Historii Filozofii Starożytnej i Średniowiecznej”, 5, 1965, s. 145-147, 153 (przedruk w: Z. Włodek, Z dziejów filozofii i teologii, s. 158-160, 166). 
1487, prepozyt Kolegium Większego 1489h, prowizor Kolegium 1494h, skarbnik Kolegium 1501, kanonik kolegiaty św. Floriana 1497, prokurator dóbr tejże 1497, dziekan Wydziału Sztuk 1489e, konsyliarz rektora 1493, 1495, członek komisji do reformy Bursy Jerozolimskiej 1495, rektor Uniwersytetu 1500h, zm. 23 I 1504 (LC, s. 35-36; BJ 2219, f. 41r, 48v, 50r, 54r, 75r; M I 69h/170; NKP 73/46B, 77/2M; AR, s. 1092; CUC, s. 477; LD, s. 3; Bukowski, Rachunki 2, s. 711, przyp. 95 - tam dalsza literatura).

\section{Autographs of Fifteenth-century Cracow Professors in the Jagiellonian University Archives, MS 63}

The article discusses autographs of Cracow University professors from between 1432-1520, found in the Jagiellonian University Archives, MS 63. The manuscript contains resolutions passed by a collegiate gathering, the corporation self-government of the Royal (Greater) College at Cracow University in the years 1432-1591. This is the first time that the manuscript has been discussed both from the codicological viewpoint and as regards its contents. Owing to the drawn-out time of the origin of the source and the multiplicity of handwritings it remains an interesting palaeographic monument. Findings concerning the nature and functioning of the college self-government as well as the contents of some entries led to the conclusion that the manuscript was written down by numerous professors of Cracow University - members of the Royal College. The research resulted in a catalogue of 26 identified autographs edited in the form of schematic notes about the authors, accompanied by facsimile examples of their handwriting. The handwriting of e.g. Andrzej Grzymała of Poznań, Bartłomiej of Radom, Jan of Stobnica, Jan of Dąbrówka, Marcin Biem of Olkusz, Michał Sternberg of Lgota (Oleśnica), Michał of Wielun, and Stanisław Bylica of Olkusz was identified.

Kontakt do autora: dagmara.wojcik@uj.edu.pl 